\title{
Chic, chèque, choc
}

Transactions autour des corps et stratégies amoureuses contemporaines

\section{Dirigé par Françoise Grange Omokaro et Fenneke Reysoo}

Les Actes des colloques genre de l'Institut de hautes études internationales et du développement Collection Yvonne Preiswerk

T. Schweizerische Eidgenossenschaft

Confédération suisse

Confederazione Svizzera

Confederaziun svizra

Direction du développement

et de la coopération DDC

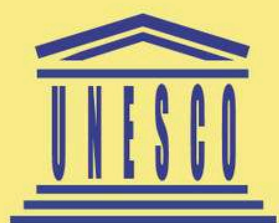

THE GRADUATE INSTITUTE | GENEVA

INSTITUT DE HAUTES ÉTUDES

INTERNATIONALES ET DU DÉVELOPPEMENT

GRADUATE INSTITUTE OF INTERNATIONAL

AND DEVELOPMENT STUDIES

Genève, Berne, 2012

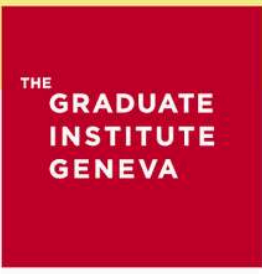

INSTITUT DE HAUTES

INSTITUT DE HAUTES

ET DU DÉVELOPPEMENT

GRADUATE INSTITUTE

OF INTERNATIONAL AND

DEVELOPMENT STUDIES

NOUVELLE ÉDITION

\section{GENRE ET DÉVELOPPEMENT | RENCONTRES}




\section{Graduate Institute Publications}

GRADUATE

INSTITUTE

GENEVA

\section{Chic, chèque, choc}

Transactions autour des corps et stratégies amoureuses contemporaines

\section{Françoise Grange Omokaro et Fenneke Reysoo (dir.)}

DOI : 10.4000/books.iheid.6326

Éditeur : Graduate Institute Publications

Lieu d'édition : Genève

Année d'édition : 2012

Date de mise en ligne : 20 juillet 2016

Collection : Genre et développement. Rencontres

EAN électronique : 9782940503841

\section{OpenEdition}

\section{Books}

https://books.openedition.org

\section{Édition imprimée}

Nombre de pages : 182

\section{Référence électronique}

GRANGE OMOKARO, Françoise (dir.) ; REYSOO, Fenneke (dir.). Chic, chèque, choc : Transactions autour des corps et stratégies amoureuses contemporaines. Nouvelle édition [en ligne]. Genève : Graduate Institute Publications, 2012 (généré le 28 janvier 2022). Disponible sur Internet : <http:// books.openedition.org/iheid/6326>. ISBN : 9782940503841. DOl : https://doi.org/10.4000/ books.iheid.6326. 


\section{RÉSUMÉS}

L'on peut se demander si l'étude du «sexe» est pertinente pour le champ des études de « développement » et des « relations internationales ». Au delà des politiques et interventions de développement liées à la " population », au « planning familial » et à la " prévention des maladies sexuellement transmissibles et du VIH », cet ouvrage propose une réflexion sur les transactions amoureuses et sexuelles à l'ère de la mondialisation. Sur quoi les échanges sexuels portent-t-il ? Selon quelles modalités de réciprocité ou d'asymétrie ? L'ouvrage explore également les dynamiques de genre. Les registres "traditionnels" de féminités et de masculinités semblent ébranlés par les échanges economico-sexuels contemporains. Que signifie alors être un homme ou une femme dans ces nouvelles configurations identitaires?

\section{FRANÇOISE GRANGE OMOKARO (DIR.)}

Anthropologue, IHEID, Genève.

FENNEKE REYSOO (DIR.)

Anthropologue, IHEID, Genève. 


\title{
Chic, chèque, choc
}

\section{Transactions autour des corps et stratégies amoureuses contemporaines}

\author{
Dirigé par Françoise Grange Omokaro \\ et Fenneke Reysoo
}

Les Actes des colloques genre

de l'Institut de hautes études internationales et du développement

Collection Yvonne Preiswerk

Schweizerische Eidgenossenschaft

Conféderation suisse

Confederazione Svizzera

Confederaziun svizra

Direction du développement

et de la coopération DDC 
Institut de hautes études internationales et du développement

Case postale 136

$\mathrm{CH}$ - I2I I Genève 21

http://graduateinstitute.ch

Pôle genre et développement de l'Institut http://graduateinsttitute.ch/genre

Service des Publications

publications@graduateinstitute.ch

ISBN 978-2-940503-06-3 
Cet ouvrage prolonge le colloque international

\section{Chic, chèque, choc}

\section{Transactions autour des corps et stratégies amoureuses contemporaines}

qui s'est tenu en octobre 2007 à Genève à l'Institut universitaire d'études du développement (IUED), devenu Institut de hautes études internationales et du développement (IHEID) en 2008.

Le thème de ce colloque est issu d'une recherche menée en Afrique de l'Ouest dans le cadre du projet "Genre et droits en santé de la reproduction» (IUED-OMS) financé par le RUIG (Réseau universitaire international de Genève) (2004-2006), devenu SNIS (Swiss Network of International Studies).

Le colloque a été organisé grâce au soutien logistique et financier de:

- La Commission suisse pour l'UNESCO, Berne

- La Direction pour le développement et la coopération du Département fédéral des affaires étrangères (DDC), Berne

- Le Réseau suisse pour les études internationales (SNIS, ex RUIG)

- L'Institut universitaire d'études du développement (IUED), Genève

Qu'ils soient ici remerciés ainsi que toutes les personnes qui ont participé à la réussite de ce colloque. 


\section{Dans la même collection}

Femmes, villes et environnement. Textes réunis par Yvonne Preiswerk et Isabelle Milbert. Genève: IUED/DDC/UNESCO. 1995. 229 p. (épuisé)

Créativité, femmes et développement. Textes réunis par Yvonne Preiswerk, avec la collaboration de Marie Thorndahl. Genève: IUED/DDC/UNESCO. 1997. 265 p. (épuisé)

Les silences pudiques de l'économie. Economie et rapports sociaux entre hommes et femmes. Textes réunis par Yvonne Preiswerk, avec la collaboration de Anne Zwahlen. Genève: IUED/DDC/UNESCO. 1998. 28I p. (épuisé)

Tant qu'on a la santé. Les déterminants socio-économiques et culturels de la santé dans les relations sociales entre les femmes et les hommes. Textes réunis par Yvonne Preiswerk, avec la collaboration de Mary-Josée Burnier. Genève: IUED/DDC/UNESCO. 1999. 279 p. (épuisé)

Quel genre d'homme? Construction sociale de la masculinité, relations de genre et développement. Textes réunis par Christine Verschuur, coll. Yvonne Preiswerk, Genève: IUED/DDC/UNESCO, 2000. 190 p. (épuisé)

Hommes armés, femmes aguerries. Rapports de genre en situations de conflit armé. Textes réunis par Fenneke Reysoo. Coll. Yvonne Preiswerk. Genève: IUED/DDC/UNESCO. 200 I. 250 p. (épuisé)

Économie mondialisée et identités de genre. Textes réunis par Fenneke Reysoo. Coll.Yvonne Preiswerk. Genève: IUED/DDC/UNESCO. 2002. 250 p.

On m'appelle à régner. Mondialisation, pouvoirs et rapports de genre. Textes réunis par Fenneke Reysoo et Christine Verschuur. Coll.Yvonne Preiswerk. Genève: IUED/DDC/UNESCO. 2003. 258 p.

Femmes en mouvement. Genre, migrations et nouvelle division internationale du travail. Textes réunis par Fenneke Reysoo et Christine Verschuur. Coll. Yvonne Preiswerk. Genève: IUED/DDC/UNESCO. 2004. 284 p. 
Des brèches dans la ville. Organisations urbaines, environnement et transformation des rapports de genre. Textes réunis par Christine Verschuur et François Hainard. Coll.Yvonne Preiswerk. Genève: IUED/DDC/UNESCO. 2006. 294 p.

Vents d'Est, vents d'Ouest. Mouvements de femmes et féminismes anticoloniaux. Textes réunis par Christine Verschuur. Coll. Yvonne Preiswerk. Genève: IHEID/DDC/UNESCO. 2009. 255 p.

Du grain à moudre. Genre, développement rural et alimentation. Dirigé par Christine Verschuur. Coll. Yvonne Preiswerk. Genève/Berne: IHEID/ DDC/UNESCO/.20II. 479 p.

Les Actes des colloques genre - Collection Yvonne Preiswerk sont disponibles gratuitement au service des Publications de l'IHEID ou en ligne sur le site Internet du Pôle genre et développement de l'IHEID: http://graduateinstitute.ch/genre/publications/actes_colloques_fr.html 
Le colloque 2007 «Chic, chèque, choc. Transactions autour des corps et stratégies amoureuses contemporaines ॥ a été organisé sous la responsabilité de Françoise Grange Omokaro et de Fenneke Reysoo avec la collaboration de nombreuses autres personnes.

Ce colloque était le onzième colloque international genre et développement organisé à Genève depuis 1994 sur la problématique des inégalités de genre dans le développement

\section{Ont collaboré à la réalisation de ce colloque et de cet ouvrage :}

Les intervenantes et intervenants (dans l'ordre de leur intervention au colloque):

Michel Carton

Françoise Grange Omokaro

Fenneke Reysoo

Véronique Mottier

Paola Tabet

Colette Harris

Pimpawun Boonmongkon

Mériam Cheikh

Quach Thi Thu Trang

Getnet Tadele

Cristine Fuentes Zurita

Theresa Ujano Batangan
Directeur de l'Institut universitaire d'études du développement (IUED), devenu l'Institut de hautes études internationales et du développement (IHEID) en 2008

IHEID, Genève, Suisse IHEID, Genève, Suisse

Université de Lausanne, Suisse, et Cambridge University, Royaume-Uni Université de Calabre, Italie Institute of Development Studies and East Anglia University, Royaume-Uni Center for Health Policy Studies, Mahidol University, Thaillande Institut d'Ethnologie Méditerranéenne et Comparative, MMSH/Aix-en-Provence, France

Consultation of Investment in Health Promotion (CIHP), Hanoi,Vietnam Addis Ababa University, Éthiopie Universidad autónoma metropolitana (UAM)-Iztapalapa, Mexique University of the Philippines, Diliman 
Benjamin Makhubele

Joëlle Schwarz

Larissa Barbosa

Jane Cottingham

Milena Mihajlovic
Centre for AIDS Development, Research and Evaluation (CADRE), Afrique du Sud Institut tropical et de santé publique suisse (Swiss TPH), Bâle, Suisse IHEID, Genève, Suisse

Organisation mondiale de la santé, Genève, Suisse

Direction pour le développement et la coopération, Suisse

Les modérateurs et modératrices (dans l'ordre de leur intervention):

Séverine Rey

Cristine Fuentes Zurita

Maïmouna Ndoye

Claudine Sauvain-Dugerdil

Rina Nissim

Christine Verschuur
Université de Lausanne, Suisse

Universidad autónoma metropolitana (UAM)-Iztapalapa, Mexique

IHEID, Genève, Suisse et Association des femmes africaines pour la recherche et le développement (AFARD)

Laboratoire de démographie et d'études familiales, Université de Genève, Suisse Espace Femmes International, Genève, Suisse

IHEID, Genève, Suisse

Les membres du comité scientifique:

Françoise Grange

Fenneke Reysoo

Christine Verschuur

Milena Mihajlovic

Suzanne Lerch

Rina Nissim

Jane Cottingham
IHEID, Genève, Suisse

IHEID, Genève, Suisse

IHEID, Genève, Suisse

Direction pour le développement et la coopération, Suisse

Espace Femmes International, Genève, Suisse

Espace Femmes International, Genève Suisse

Organisation mondiale de la santé, Genève, Suisse 
Les interprètes:

Claire Alder Goldblat, Kathy Bijleveld-Hari, Françoise Globa, Rian Monnahan, Nathalie Reichert.

Les collaboratrices principales pour les questions organisationnelles et logistiques:

Camille Gobet Stagiaire-assistante

Sylviane Werren Kanyarwunga IHEID

Gilberte Torche IHEID

L'équipe des étudiant-es chargée de la logistique.

Les collaborateurs et collaboratrices pour la publication de l'ouvrage:

Catherine Fragniere IHEID

Françoise Ujhazi Atelier Françoise Ujhazi, Genève

La documentaliste genre à la bibliothèque de l'IHEID:

Isabelle Vuillemin-Raval

Les relectrices:

Emmanuelle Chauvet

IHEID

Marlyne Sahakian

IHEID

Béatrice Steiner

IHEID

Exposition photo «Présentement ça bouge à Bamako!» réalisée par Françoise Grange Omokaro et Amy Peck. 


\section{Table des matières}

Du genre et droits reproductifs aux constructions identitaires de genre

Françoise Grange Omokaro et Fenneke Reysoo

p. II

The Invention of Sexuality

Véronique Mottier

Through the Looking-Glass: Sexual-Economic Exchange

p. 39 Paola Tabet

Seductive consumption. The influence of pornography on marital sexual demands in Tajikistan

Colette Harris

Féminités et masculinités en mouvement:

échanges économico-sexuels à Bamako

p. 7I

Fenneke Reysoo

L'amour, le sexe et l'argent au Maroc:

une sexualité dans tous ses états

p. 92

Mériam Cheikh

Transactions autour des corps et insertion en Suisse.

Des Camerounaises qui «se débrouillent» à Lausanne Joëlle Schwarz

Love, money and construction of masculinity among young people in Dessie town

Getnet Tadele

Sexual identity, sexual relationships and risk among young people in South Africa

p. 107

M'zamani Benjamin Makhubele, Pumla Ntlabati

p. 153 and Warren Parker 
Pag-ibig (Love), Pagnanasa (Desire):

Filipino adolescents and sexual risks

p. 169

Maria Theresa D. Ujano- Batangan 


\title{
Du genre et droits reproductifs aux constructions identitaires de genre
}

\author{
Françoise Grange Omokaro* \\ et Fenneke Reysoo**
}

\section{« Sex and Development ": un enjeu pour la pensée critique sur les politiques de développement}

L'on peut se demander si l'étude du «sexe» est pertinente pour le champ des études de «développement» et des «relations internationales ». La simple question nous fait penser aux paroles de Bill Clinton en 1998: "I did not have sexual relations with that woman». Une relation sexuelle out of place était alors une menace pour la continuation de l'exercice de la fonction de président des États-Unis. En outre, dix jours seulement avant notre colloque en 2007 , le gouvernement néerlandais venait de publier une «Politique contre la sexualisation de la société » (Direction de l'Émancipation, ler octobre 2007). Comment se fait-il que les questions de «sexe» soient devenues le centre des préoccupations politiques? Que pourront les politiques? Et comment les

Anthropologue, Institut de hautes études internationales et du développement, francoise.grange@graduateinstitute.ch

* Anthropologue, Institut de hautes études internationales et du développement, fenneke.reysoo@graduateinstitute.ch

Grange Omokaro, F. et F. Reysoo. 20 I2. Introduction. Du genre et droits reproductifs aux constructions identitaires de genre. In Chic, chèque, choc. Transactions autour des corps et stratégies amoureuses contemporaines. II-22. Actes des colloques genre et développement. Berne: DDC-Commission suisse pour I'UNESCO; Genève: IHEID. 
questions de «sexe» ont-elles été insérées dans les programmes et projets de développement?

Pour vous donner des éléments de réflexion et de réponse, nous aimerions ouvrir ce colloque par la présentation de quelques jalons importants des politiques et interventions de développement liées à la «population», au «planning familial», à la «prévention des maladies sexuellement transmissibles et du $\mathrm{VIH}$ » et à la «sexualité ».

Après la Deuxième guerre mondiale, lors de la période de reconstruction économique de l'Europe et du Japon, et pendant que les États africains et asiatiques revendiquaient leurs indépendances, les leaders du monde étaient préoccupés par la stabilité politique, par la croissance économique et la «bombe» démographique (population bomb). Inspirés par la théorie malthusienne, ils percevaient une croissance démographique débridée, notamment dans les pays du Sud, comme un danger pour l'avenir de la planète entière. La réponse politique visait à contrôler la population par des mesures cherchant à infléchir les tendances démographiques considérées comme déstabilisantes, telles les taux de natalité et de fécondité élevés. L'émergence de politiques de population, avant tout dans les pays du Sud, a eu lieu alors que parallèlement se développait un intérêt accru pour les recherches sur les méthodes contraceptives hormonales dans les pays industrialisés. La logique mise en place était que, les femmes portant les enfants, la réduction des taux de fécondité élevés impliquait d'inventer et de produire des méthodes contraceptives agissant sur le corps de celles-ci. C'est à la fin des années 1950 que la pilule contraceptive fut inventée et lancée sur le marché. La consommation massive de la pilule contraceptive allait - pensait-on - pouvoir résoudre les menaces de déstabilisation politique. Dans cet esprit, lors de la conférence internationale sur la population à Bucarest (1974), on souscrivait à l'adage: "La pilule est le meilleur développement».

Dans ce contexte global, et avec cette nouvelle méthode de contraception, dite moderne, des politiques de population pouvaient être mises en œuvre au travers de programmes de planning familial. Ces programmes s'intégraient parfois dans les Ministères de la santé, mais ils étaient plus souvent mis en place comme des programmes verticaux relativement autonomes. Dans la plupart des cas, ces programmes furent financés par des bailleurs de fonds étrangers ou à travers l'aide multilatérale (FNUAP). 
Dans la décennie suivante, en 1984, fut organisée une nouvelle Conférence internationale sur la population à Mexico. L'institutionnalisation avancée des programmes de planning familial et l'attention unilatérale portée sur la fécondité et sur les corps des femmes commencèrent à susciter des réactions adverses par les défenseurs de la santé et des droits des femmes. En effet, par souci d'efficience, les programmes de planning familial avaient défini des cibles quantitatives passablement coercitives pour faire accepter aux femmes mariées d'âge reproductif l'utilisation d'une méthode contraceptive moderne (pilule, injection, stérilet, implants, stérilisation). Dans certains pays, des systèmes de récompenses ou de sanctions négatives étaient même prévus pour les prestataires de service en vue d'arriver aux objectifs quantitatifs fixés (faire diminuer le taux de croissance démographique de quelques points en peu de temps, augmenter la prévalence contraceptive, etc.) (Reysoo, Huq et van der Kwaak 1995).

Lors de la Conférence internationale sur les femmes à Nairobi, en 1985, s'est joué un moment clé pour l'organisation de la résistance à ces politiques top-down, coercitives et abusives, grâce au mouvement international des femmes, et plus particulièrement au mouvement international de la santé des femmes'. Parallèlement, l'analyse des problèmes de développement s'était élargie et il était devenu clair que la dégradation environnementale n'était pas seulement causée par un taux de natalité élevé dans les pays du Sud, mais également par les modes de production et surtout les modes de consommation dans les pays du Nord. Dix ans plus tard, en 1994, la Conférence internationale sur la population au Caire a vu s'adjoindre à son intitulé et à ses débats le «D» de développement. La CIPD a été l'une des conférences internationales organisées par les Nations unies dans les années 1990 où les questions de développement ont été débattues avec une perspective sensible aux problématiques plus larges (environnement, droits, questions sociales) et où les questions d'égalité de genre et les droits des femmes ont été mondialement reconnus (Rio de Janeiro sur l'environnement en 1992, Vienne sur les droits humains

1 En fait c'est lors de la 4e rencontre du Mouvement international de la santé des femmes à Amsterdam en 1984 qu'ont été lancés les nouveaux concepts de droits reproductifs et santé reproductive en lien étroit avec la lutte contre les avortements à risques et les méthodes contraceptives hors du contrôle des utilisatrices. 
en 1993, Le Caire avec la CIPD en 1994, Copenhague avec le Sommet social en 1995 ainsi que Beijing sur les femmes en 1995).

La CIPD a constitué un moment particulièrement important pour le mouvement international des femmes. Non seulement, elle a marqué un changement paradigmatique dans les politiques de population qui sont passées de cibles quantitatives à des choix autonomes en matière de reproduction, mais elle a également introduit un changement conceptuel (santé reproductive, santé sexuelle, droits reproductifs et droits sexuels) qui impliquait la transformation d'une approche orientée étroitement sur la santé en une approche élargie vers une base de droits reproductifs (Reysoo et Appelman 1994). En matière de planning familial, l'intégration de la responsabilité des hommes dans les questions de reproduction humaine a été explicitée. Et lors de la discussion de tous les chapitres du Programme d'Action du Caire, les questions d'égalité et d'équité de genre et l'empowerment des femmes et des filles ont eu une place centrale.

Toutefois, l'introduction d'un nouveau cadre conceptuel ne pouvait pas à elle seule garantir que le sens des nouveaux concepts soit intégré. Les acteurs politiques et les décideurs de la santé n'avaient pas assimilé immédiatement le potentiel transformateur de l'approche de la reproduction humaine en remplaçant les cibles par les considérations de droits et d'éléments qualitatifs, tels que la culture, les valeurs, les rapports sociaux de sexe, la subjectivité et l'éthique.

Pour pouvoir mettre en œuvre des politiques de santé reproductive et sexuelle qui tiennent compte des aspects qualitatifs et identitaires des relations entre partenaires et la signification de leur sexualité, les connaissances étaient insuffisantes. C'est alors qu'une multitude d'études sur les rapports sociaux de sexe (genre) et l'application d'une approche basée sur les droits reproductifs ont vu le jour. Un des corollaires de ce changement paradigmatique était que les questions de reproduction humaine ne pouvaient plus être abordées de façon abstraite, quantitative et sans tenir compte du contexte socioculturel. Cela impliquait de remettre des questions liées à la sexualité explicitement sur le devant de la scène et de tenir compte des rapports sociaux de sexe comme système de domination entre hommes et femmes.

Dans ce cadre, le programme de la recherche en santé de la reproduction de l'OMS a initié un certain nombre de recherches. Une 
équipe de l'OMS a par exemple travaillé en réseau pour produire un manuel de formation afin de sensibiliser les décideurs de la santé publique aux conséquences pour les systèmes de santé de l'introduction de la perspective de genre et des droits reproductifs (Manual Transforming Health Systems: Gender and Rights in Reproductive Health). C'est ainsi qu'une équipe de chercheures de l'IHEID s'est associée en 2004 avec l'équipe de l'OMS pour traduire et adapter ce manuel aux réalités de l'Afrique de l'Ouest en matière de reproduction et de sexualité.

La perspective de genre et des droits reproductifs nous avait prédisposées à étudier les modalités de négociation des rapports sexuels entre jeunes hommes et femmes afin de fournir des informations pour les programmes de santé reproductive. Cependant, sur le terrain (à Bamako en 2005 et 2006), nous avons observé des stratégies amoureuses et des pratiques sexuelles dont les manuels de santé publique ne parlent pas. En effet, contrairement au message programmatique d'abstinence, de fidélité et d'usage du préservatif, nous avons rencontré une jeunesse sexuellement active mettant en scène des jeux identitaires basés sur des constructions de jeunes hommes et femmes inspirées d'images mondialement diffusées.

Le concept d'échange économico-sexuel de Paola Tabet (voir dans ces Actes) nous a paru adéquat pour comprendre les motivations, les modalités et les stratégies des jeunes hommes et femmes qui se lancent dans les relations sexuelles.

\section{Les échanges économico-sexuels (Tabet 2004)}

Pour sortir d'un discours moral et d'une vision des politiques publiques qui réduirait à un utilitarisme économique ces transactions sexuelles et amoureuses, il y a tout d'abord nécessité de les informer et de les documenter.

Ce qui, au plan méthodologique, n'est pas chose aisée car nous sommes face à des pratiques individuelles et sociales qui se situent à la fois au centre et à la marge du social. D'une part nous nous trouvons face à des pratiques qui semblent généralisées, voire banalisées et quantifiées: ainsi à Bamako, le directeur d'une caisse de micro-crédit nous dira: "Quand tu prends aujourd'hui 100 filles dans le quartier ici, tu vas trouver 40 ou 50 filles qui font ce genre de chose» et elles sont 
alors présentées comme des faits reconnaissables, visibles d'un point de vue sociologique. D'autre part, du côté des normes sociales et culturelles, elles sont de l'ordre du tabou, de la marginalité, voire de la subversion et de l'illégalité, à tel point que l'on pourrait même douter de leur existence. "Le phénomène est déguisé» nous dira ce même interlocuteur.

Par conséquent, l'éclairage qui sera privilégié dans ce colloque pour appréhender ces pratiques sera celui d'une approche émique et socio-anthropologique afin d'interroger leurs contenus et modalités à partir du sens que leur donnent les acteurs sociaux. En ouverture de nos réflexions, nous examinons les sémantiques locales dont elles font l'objet dans un certain nombre d'expressions populaires. Certaines, par effet de caricature, voire de stigmatisation, désignent des rôles de genre et des postures de classe. D'autres se structurent autour de la dimension économique. La part financière des transactions exprime alors les aspirations de leurs "bénéficiaires » à une culture matérielle du luxe. Nous pouvons en établir la typologie suivante:

I. soit elles caractérisent une partition des rôles des partenaires ou la spécificité du lien relationnel;

2. soit elles ciblent des groupes sociologiques situés aux deux extrémités de l'échelle sociale;

3. soit elles sont appliquées aux biens et ressources qui motivent les transactions.

Ad I) Nous avons repris, pour l'intitulé de ce colloque, l'expression "Chic, chèque, choc » qui distingue le chic - le partenaire «beau mec bien habillé»-, le chèque - «pourvoyeur, l'argentier»-, et le choc «l'élu du cœur», expression répandue en Afrique de l'Ouest francophone avec diverses variantes. Au Niger, on dira le beau, le riche, le cœur.

On trouve un certain nombre d'expressions pour caractériser la posture socio-économique dominante du partenaire. Au Ghana, au Cameroun, au Swaziland ou dans certains pays d'Europe de l'Est, on parle de «sponsors». En Côte d'lvoire, le terme grotto désigne un homme jouissant d'une aisance financière, généralement plus âgé et marié, qui entretient des relations sexuelles avec une étudiante qu'il aide financièrement. Et celui de gnanhy pour une femme jouissant également 
d'une position économique favorable, plus âgée, mariée ou non, qui aide financièrement un étudiant en échange de relations sexuelles.

De la même façon, les expressions de sugar daddies ou sugar mummies soulignent le caractère intergénérationnel de la relation et son organisation non seulement au féminin, mais aussi au masculin. Ainsi L'Indépendant, journal béninois, intitulait un article consacré à ce sujet (octobre 2006) «Les femmes s'offrent des "bureaux" sans état d'âme».

Ad 2) Au sommet de la hiérarchie sociale, en plus des hommes et femmes nantis déjà mentionnés, on pointe les étudiants et les étudiantes ou les filles BCBG (bon chic bon genre) qui «tapinent par goût du luxe» comme le titrait récemment un hebdomadaire genevois. Au bas de l'échelle sociale, ce sont les jeunes en situation de migration. $\grave{A}$ Bamako, les jeunes filles de la campagne placées en ville comme employées de maison, sont présentées soit comme des victimes et des proies faciles en raison de leur absence d'éducation, de leur naïveté à cause desquelles elles se "feraient avoir», soit comme des arrivistes qui chercheraient à transgresser l'ordre social pour ressembler à leurs «patrons» et les toiser dans l'ostentation.

Ad 3) Diverses terminologies désignent les biens ou activités de luxe pouvant être obtenus via les échanges économico-sexuels: «4C» (car, cellular phone, cash, clothes), « $3 \mathrm{~V} »$ (villa, vidéo, voiture) «JTH» (Jakarta - petite moto chinoise au Mali -, téléphone, hôtel). En Occident, on parle de «prostitution accessoire» ou de «prostitution sac à main $»$.

La prise en compte du regard des acteurs, et plus particulièrement des actrices, engagés dans les échanges économico-sexuels fait apparaître d'autres logiques sociales mais également des stratégies et des positionnements personnels. Un extrait de l'article «Comment se débrouille-t-on à Bamako lorsqu'on est jeune, jolie et sans argent? En sachant parler aux hommes» paru dans la presse locale bamakoise (L'Essor 4 octobre 2006) nous en donne une illustration. II évoque la trajectoire de réussite économique par la séduction et la reconnaissance sociale, mais aussi la gestion subtile de plusieurs relations entre opportunités de rencontre et élections personnelles:

Moi, je vis avec 5 hommes différents... l'un est commerçant, l'autre fonctionnaire, le troisième entrepreneur et les deux autres hommes d'affaires... J'ai fait la connaissance de mon premier 
garçon, le commerçant. Au début il me gâtait beaucoup. C'est de lui que j'ai reçu en un seul coup et pour la première fois de ma vie 100 '000 CFA... J'ai commencé à sortir avec l'entrepreneur qui me rôdait déjà autour. L'homme était tellement content de m'avoir qu'il m'a même acheté un Yamaha mate $50 \ldots$ J'ai jonglé une année entre ces deux amoureux avant de me mettre avec le premier homme d'affaires qui m'a acheté mon premier cellulaire. J'ai fait la connaissance du fonctionnaire au cours d'un voyage en Illème Région là où vivent mes parents... le cinquième... c'est en cherchant une puce Ikatel que je l'ai connu. Il est bel homme et il m'a attiré immédiatement... II y a deux semaines, mon premier homme d'affaires m'a offert une voiture, une Mercedes 190. J'ai donc donné la moto à mon petit frère. II faut bien me comprendre. Je ne suis pas une prostituée, mais j'essaie d'améliorer ma situation. À ce jour, j’ai commencé à construire une maison en ciment pour mes parents dans le village et quand ce chantier prendra fin, je vais tout arrêter pour me marier et donner un sens à ma vie.

Ainsi nous sommes face à des relations sexuelles et amoureuses qui peuvent s'inscrire dans un multi-partenariat ou non. Elles sont dynamiques et peuvent se faire et se défaire. Enfin, elles combinent de façon complexe sentiment amoureux, sexualité et ressource matérielle.

Il n'y a pas donc pas un modèle unique mais un «chic, chèque, choc » à géométrie variable allant:

- d'une relation intergénérationnelle entre deux partenaires dans la longue durée

- jusqu'à des relations pouvant mobiliser un nombre plus important de partenaires

- en passant par des transactions de redistribution entre les partenaires où les ressources obtenues du «chèque» pourront être redirigées vers le «choc» ou vers la famille.

C'est pourquoi, afin de cerner et d'analyser ces pratiques, nous avons opté pour des études de cas ancrées dans des contextes géographiques et culturels divers afin d'atteindre également une perspective comparative: sommes-nous dans une mouvance globale? Et quelles en sont les caractéristiques? 


\section{Modalités et contenus des échanges économico- sexuels}

Que se passe-t-il dans ces transactions amoureuses et sexuelles? Sur quoi l'échange porte-t-il? À quel moment de la relation et selon quelles modalités de réciprocité ou d'asymétrie se produit-il? Dans quels lieux?

Plusieurs registres sont à l'œuvre comme on pourra le voir dans les différentes études de cas qui seront présentées dans ce colloque:

- le registre émotionnel et amoureux: l'amour, l'affection, l'amitié

- le registre sensuel et du plaisir: le jeu sexuel et érotique, la découverte et l'expérience

- le registre du pouvoir: compétition, domination, soumission, manipulation

- le registre de la reconnaissance sociale et du prestige

- le registre de la reproduction et de la contraception: désir d'enfants ou enfant non désiré, filiation et statut des enfants qui peuvent naître de ces échanges

- le registre économique: avantages, bénéfices matériels et financiers

Mais ne retrouve-t-on pas là les éléments de n'importe quelle relation amoureuse et sexuelle reconnue et gérée par un code social et moral? Quelle est alors la spécificité de la transaction autour du bénéfice économique? C'est pourquoi il nous semble fondamental de ré-interroger la place de la dimension économique dans les relations hétérosexuelles à la lumière de la notion d'«échange économico-sexuel» conceptualisée par Paola Tabet.

Ces transactions sexuelles et amoureuses révèlent les stratégies d'acteurs et d'actrices et leurs constructions identitaires en décalage, comme on l'a déjà souligné, avec les représentations normatives et coercitives des politiques nationales et internationales notamment visà-vis de la contraception et du sida.

Quel sens les protagonistes donnent-ils eux-mêmes à leurs propres pratiques? Visiblement pas celui de pratiques incluses dans une forme de prostitution généralisée ou institutionnalisée. Serait-on 
alors en face de nouvelles normes sexuelles? Ou de l'émergence de formes d'émancipation? D'une révolution sexuelle? Et en même temps, ces transactions seraient-elles apparentées au cycle de vie de la jeunesse, la norme restant le contrôle de la sexualité des femmes au sein de l'institution du mariage? Pour éclairer cette tension entre un contrôle politique, social et moral de la sexualité dans la ligne de Foucault et l'émergence d'un sujet émancipé au sens de Giddens, nous reviendrons avec Véronique Mottier (dans ces Actes) sur la sexualité comme construction sociale.

En postulant des recompositions identitaires de genre, nous souhaiterions les aborder selon deux axes:

\section{Les transactions comme pratiques sociales de Ia mondialisation}

Que nous disent les objets, les services et les ressources qui motivent ces échanges? Ils sont tantôt associés à la nécessité (survie), tantôt à la futilité (le luxe), tantôt au prestige et à l'ostentation. II nous semble nécessaire de replacer ces pratiques dans le contexte de la mondialisation selon un double mouvement. D'un côté on considérera la consommation comme une contrainte sous la forme de son pouvoir de séduction relayé par les médias, les cultures musicales et des loisirs: une manchette titrait récemment «Les filles accros au téléphone portable». Dans ce sens il serait impossible d'échapper à la consommation de certains biens au risque de n'être personne et d'être stigmatisé du côté de la pauvreté. De l'autre, on se demandera si ce désir effréné de consommation n'est pas une manière de se rendre maître de son destin et ne serait pas alors le support d'une construction de soi et d'une transformation du rapport au corps.

Dans un tel processus identitaire, les objets pourraient être lus comme un prolongement du corps: téléphone cellulaire, MP3, clefs de voiture et de moto, marques de vêtements, de chaussures, de sacs à main procèdent d'une mise en scène dans la sphère publique et notamment dans les activités de loisirs. Ainsi, au delà de leur plus-value marchande, on pourrait les voir comme participant d'une pratique sociale de la mondialisation (en référence à Bayard 2004) et s'articulant sur le double mode de l'uniformisation (ce sont les mêmes biens que l'on souhaite posséder à l'échelle planétaire) et de la distinction (il 
faut être en mesure d'acquérir ceux qui sont situés en haut de la hiérarchie).

Et sur ce point, il faut souligner que les acteurs sociaux, dans un processus d'appropriation, opèrent des classifications sémantiques des objets mondialisés qui renvoient à une hiérarchie socio-économique. Ainsi, au Mali, un vieux modèle de téléphone portable sera taxé de «talkie walkie» alors que le dernier modèle de Nokia sera appelé un «serpent», au Burkina une Yamaha dame $80 \mathrm{~cm}^{3}$ sera appelée «mon mari est capable» et si c'est une mobylette chinoise pas chère «Tonton n'a pas d'argent». Un vieux modèle de Mercedes sera taxé de «mon père était riche».

Le corps serait alors à la fois porteur d'«un idéal transnational» (Biaya 200I), érotisé, paré, survalorisé et même virtualisé et médiateur de la consommation au travers des échanges économico-sexuels: nous réserverons une session de ce colloque à l'approfondissement de cette relation entre corps et consommation.

\section{Les échanges économico-sexuels comme dynamiques de genre}

La seconde voie que nous aimerions explorer est celle des dynamiques de genre. Les registres «traditionnels » de féminités et de masculinités semblent ébranlés dans ces pratiques transactionnelles. Que signifie alors être un homme ou une femme dans ces nouvelles configurations identitaires?

La mobilisation rapide de ressources importantes induit-elle une conquête de l'espace public pour les jeunes femmes alors, que dans un mouvement inverse, les jeunes hommes se retrouveraient en posture de retrait par leur faible pouvoir d'échange économique?

Sommes-nous alors face à des pratiques de subversion des jeunes filles et des femmes vis-à-vis d'une masculinité virile et "pourvoyeuse» traduisant un processus d'empowerment inédit et de revendication des bénéfices de la croissance économique, ou assistons-nous à une instrumentalisation des corps qui deviendraient les «marques» de distinction, au même titre que Gucci, Dolce \& Gabbana, Vuitton... des élites qui concentrent pouvoir politique et capacité de débourser? 


\section{Références bibliographiques}

Appelman, S. et F. Reysoo (Eds). 1994. Everything you always wanted to know... Lexicon and comments on the new population concepts from a gender perspective. Oegstgeest: Network of Gender Experts in Development Agencies in the Netherlands/Vrouwenberaad Ontwikkelingssamenwerking.

Bayard, J. F. 2004. Le gouvernement du monde: une critique politique de la globalisation. Paris: Fayard.

Biaya, T. K. 200I. Les plaisirs de la ville: masculinité, sexualité et féminité à Dakar (1997-2000). African Studies Review. 44(2) : 7I-85.

Reysoo, F., A. van der Kwaak et N. Huq, 1995. The Incentive Trap:A Study of Coercion, Reproductive Rights and Women's Autonomy in Bangladesh. Leiden: Research Information Centre, Leiden University/Dhaka: Narripokkho.

Tabet, P. 2004. La Grande Arnaque. Sexualité des femmes et échange économico-sexuel. Paris: L'Harmattan (Bibliothèque du féminisme). 


\title{
The invention of sexuality
}

\author{
Véronique Mottier*1
}

Sex is a cultural object. We tend to think of sexuality as a natural force, driven by biological instincts, and as a "private" experience perhaps as private as it gets. In contrast, I will argue in this chapter that, just as the differences between men and women cannot be reduced to biological factors alone but are more adequately understood in terms of the concept of "gender" which takes into account the social meanings that different societies attach to masculinity and femininity, sexuality is not a natural, biological and universal experience. Nor is it a purely "private" matter. The ways in which different cultures and different time periods have made sense of erotic pleasures and dangers vary widely. Sexuality is shaped by social and political forces (including state policies), and connects in important ways to relations of power around class, race, and, especially, gender. Indeed, sex, gender, and sexuality are closely intertwined: cultural meanings

* Sociologist, Université de Lausanne and University of Cambridge,

Veronique.Mottier@unil.ch

1 Sections of this chapter are developed in greater detail in Mottier (2008; 1998). Many thanks to Françoise Grange, Mireille Lador, Fenneke Reysoo and participants in the Chic, chèque, choc conference for helpful comments, and to Olaf Henricson-Bell for copy-editing the text. I also thank Jesus College, Cambridge, and the Institute of Anthropology and Sociology, University of Lausanne for institutional support, and the Swiss National Science Foundation (grant 3346$61710.00)$ for research funding.

Mottier, V. 20 I2. The invention of sexuality. In Chic, chèque, choc. Transactions autour des corps et stratégies amoureuses contemporaines. 23-38. Actes des colloques genre et développement. Berne: DDC-Commission suisse pour I'UNESCO; Genève: IHEID. 
around sexuality have been structured by normative ideas about masculinity and femininity, in other words, "proper" ways for men and women to behave. Consequently, the sexual order and the gender order are mutually constitutive.

More precisely, I propose to, firstly, examine the historical invention of a particular understanding of bodily pleasures and desires - of "sexuality" - in Western culture. Secondly, I shall tease out some of the links between sexuality and social relations of power around gender and "race", in ways that are, I believe, relevant for the field of development studies. In the West, three models of sexuality have shaped cultural understandings of sex in modernity: the moral/religious model, the biological/medical model, and the cultural/social model. Although these three models have, historically, emerged successively, it is important to emphasise that they are still co-present today. Moral, biological and cultural understandings of sexuality continue to have a great influence on the ways in which sexual meanings are organised in society, politics and our everyday lives. They have important implications for the ways in which we conceptualise our sexual behaviours and identities, as well as the possibilities for personal and political transformation, for individual and collective agency.

In Antiquity, sex was of much lesser cultural concern than other areas of everyday life. What the ancients, in an economy of scarcity, were really obsessed with was food. In contrast, Christianity placed sex firmly at the centre of morality. Christian ethics gave sex a special status by declaring it to be the original sin. In pre-industrial European societies, sexual practices were thus primarily subjected to moral problematisation and categorised in relation to the religious notion of sin.

Cultural anxieties about sex intensified in response to the rapid social and political changes brought about by industrial modernisation. The linked processes of industrialisation (the development of modern, mechanised methods of production), urbanisation (the resulting increase in the proportion of the population living in urban centres) and secularisation (the decreasing importance of religious beliefs in modern society) created large urban masses in which atomised individuals were less exposed than ever before to the social and religious control of traditional pre-modern communities. As the literary critic Steven Marcus has pointed out, the $19^{\text {th }}$ century thus combined a thriving, and mostly urban, underworld of prostitution, dance halls, and 
a stark increase in the availability of pornographic material, partly driven by the development of modern print technologies, along with public prudery and sexual repression. Collective concerns about the decline in public and private morality that supposedly resulted from the impact of modernity intensified. Moral reform groups depicted sexual libertinism as a danger to the social order and to religion, while an extensive medical and advice literature warned of the dangers of sex and of sexually transmissible diseases to personal health.

\section{The biological model of sexuality}

A biological/medical model thus started to emerge in addition to the moral/religious model. The social transformations of modernity, and the Enlightenment-inspired march away from religious obscurantism towards the twin deities of science and rationality, led to new ways of thinking about sex, turning it into an object of scientific research. Modern Western understandings of sexuality can be traced back to the birth of the science of sex ("sexology") around the turn of the twentieth century. Sex became an object of scientific study in its own right, particularly in the context of medicine and the social sciences. Darwinian theory having had a major influence on the emerging social sciences, Darwin's view of sexual selection as the key to evolution also became a major impetus for the development of modern sexual science. Through the concept of sexual selection, scientific investigations were, from their beginnings, concerned with questions of heredity, degeneracy and race. A second major impetus for sex research was the growing concern with public health, in particular with prostitution, personal hygiene, and venereal disease. Sex research became closely intertwined with growing state intervention in sexual matters. It reflected the social and political concerns of the time, as well as its social hierarchies, which were heavily structured by class and gender.

Against this backdrop, sexuality was invented. The term "sexuality", in its contemporary meaning of "possession of sexual powers, or capability of sexual feelings", first entered the English language in 1879 according to the Oxford English Dictionary (OED). The first comparable occurrence in French is attributed to the somewhat obscure novelist Péladan, who wrote of the "animal drunkenness of sexuality" (l'ivresse animale de la sexualité) in his erotic novel Le vice suprême, 
published in 1884. The new concept of sexuality located sex, as an area of scientific study as well as of subjective experience, firmly in the realm of nature and biology. Sexology replaced the undifferentiated religious category of sin with the medical categories of physical and mental illness and degeneracy. In the process, it radically transformed the social meanings of sex. As the sociologist Jeffrey Weeks (1998, 142) puts it: "Sexology was simultaneously constituting and exploring a new continent of knowledge, assigning thereby a new significance to the "sexual"”."

Biological models of sexuality dominated sexual science throughout the $19^{\text {th }}$ and $20^{\text {th }}$ centuries. They conceptualised sexual behaviour as the outcome of natural, biological drives which form the basis for a variety of social experiences. Sexual normalcy and deviancy from the norm came to be defined in relation to the assumed biological naturalness of essential human reproductive instincts. As an instinctual and potentially overwhelming force, sex was at the same time seen as a possible source of social disorder. The Scottish $19^{\text {th }}$ century biologists Geddes and Thomson $(1914,148)$ thus warned against the "volcanic element in sex, quite underlying the rest of our nature and for that very reason shaking it from its foundations with tremors, if not catastrophe". Consequently, it was argued, sexual instincts need to be kept in check by society through moral control, sex education, and legislation.

A crucial feature of this biological model was its biologisation of gender difference and gender hierarchy. Claims about women's biological inferiority were variously based upon the amalgamation of femininity with motherhood, as in the 19 $9^{\text {th }}$ century English evolutionist Herbert Spencer's claim that woman's inferior intellectual capacities were caused by the fact that she had stopped at an earlier stage of evolution in order to free energy to fulfil her role in the reproduction of the species; on a basic difference in "cell metabolism", as Geddes and Thomson influentially argued; or on hormonal differences between the sexes after the discovery of sex hormones around the turn of the $20^{\text {th }}$ century. Such claims were also used to legitimise the continued exclusion of women from the public sphere and politics in a context where such exclusion became increasingly contested.

The innate biological differences between men and women, which justified their assignment to different social roles, were thought to also 
lead to differences in sexual behaviour and needs. Whereas male sexuality was seen as naturally active and aggressive, women's sexuality was conceptualised as a passive response to male instincts. Female sexuality was thought to be driven primarily by reproductive and maternal instincts. Women were portrayed as having a natural preference for monogamy, while male promiscuity was caused by "the sexual demands of man's nature", as the influential 19th century psychiatrist Krafft-Ebing (I886) put it. Although some sexologists such as Havelock Ellis emphasised the importance of female sexuality and of fulfilling sex as crucial for a happy life, the $19^{\text {th }}$ century English physician William Acton expressed prevalent public opinion when he stated that "the majority of women are not much troubled by sexual feeling of any kind" (Laqueur 1990, 190).

Consequently, "excessive" sexual urges on the part of a woman were seen as abnormal. This resulted in a stark increase in the diagnosis of "female hysteria" in the course of the 19th century, a nervous disorder thought to be caused by insufficient sexual satisfaction of "excessively" passionate women. Patients were sometimes treated by manual massage of their genitals by a doctor until "hysterical paroxysm" (what contemporary terminology would describe as an "orgasm") occurred, and electrical vibrators became popular appliances with the spread of electricity to the private home. Alternatively, clitoridectomy could also be proposed. Institutions throughout Europe such as the London Surgical Home for the Reception of Gentlewomen and Females of Respectability Suffering from Curable Surgical Disease, set up in 1858, routinely offered clitoridectomy as a "cure" for conditions ranging from hysteria to nymphomania, idiocy, insanity and urinary incontinence (King 1998, I4). Success stories circulated in England of operations performed on women who had sought divorce under the new 1857 Divorce Act, a behaviour which was interpreted as an obvious symptom of mental illness, and who after the operation conceded to return to their husbands. As the last example shows, genital mutilation could be used as an instrument for the disciplining of non-normative femininity.

Representations of female sexuality varied, however, with social class and race. Working-class girls and racial "others" were generally portrayed as more sexually available or even insatiable, as reflected in erotic literature such as John Cleland's Fanny Hill (I748) and the 
anonymous My Secret Life (I888), while prostitutes were commonly depicted as hypersexual beings with rotten, corrupted bodies. The lower categories were on the assumed hierarchical scale of civilisation, the closer they were to "primitives" - which is why, in general, women were assumed to be "as a rule... much more the slaves of their instincts and habits than men", as the Swiss sexologist Auguste Forel put it. Working-class men and women, Africans, Asians and Jews (the latter considered a separate "race") were considered especially voluptuous and more likely to engage in "uncivilised", "degenerate" sexual practices.

In addition to the biologisation of gender differences, a further central feature of the biological model of sexuality was the assumption that "natural" sexual behaviour included heterosexual acts and desires only. Heterosexuality was thus treated as the implicit norm, whereas homosexuality, in particular, came to be conceptualised as, somehow, a pathological departure from the norm. Somewhat ironically, when the American doctor James G. Kiernan adopted the term "heterosexual" in its earliest known occurrence in the English language in a medical journal in 1892, he used it to describe the "sexual perversion" of having sex for recreational rather than procreative reasons via "abnormal methods of gratification", which referred to ensuring pleasure while avoiding reproduction. The association of heterosexuality with abnormal (i.e. non-procreative) craving for the opposite sex continued well into the 1920s, when an appetite for non-procreative different-sex sexuality started to be seen as the norm.

The biological model conceptualised people who engaged in deviant sexual practices as fundamentally, biologically different from others. This was an important conceptual innovation, which can be illustrated with the concept of the "homosexual". Of course, same-sex practices have always occurred throughout history and specific acts such as sodomy have been tolerated at times and persecuted at others (in Europe, most intensely in the $18^{\text {th }}$ century). However, any person - depending on their lack of morality - was thought to be capable of such sinful practices. As Foucault (1990) famously pointed out, it was only much later, beginning in the $19^{\text {th }}$ century, that the idea started to emerge that people who engage in "sodomy" are a separate type of person, with a specific identity and inclinations resulting from abnormal biological instincts which lead them to commit such acts: or 
"homosexuals". As Foucault $(1990,43)$ put it:"The sodomite had been a temporary aberration; the homosexual was now a species".

While some historians trace the beginnings of this change back to the late Middle Ages and point out that from the $17^{\text {th }}$ and $18^{\text {th }}$ centuries onwards a certain homosexual subculture, with specific meeting places, started to form in large European cities, it is certain that with the 19 th $^{\text {th }}$ century conceptualisation of the sodomite as a particular type of person, the modern homosexual was born. A Hungarian journalist born in Vienna, Karl-Maria Kertbeny, is generally credited with coining the term "homosexual", first in a letter to Karl Heinrich Ulrichs, an early German advocate for the rights of sexual minorities, in 1868, then publicly in an anonymous pamphlet of 1869 campaigning against Prussian sodomy legislation. Kertbeny contrasted the homosexual initially to the "monosexualist" (someone who masturbates), the "heterogenist" (someone who has sex with animals) and the "heterosexual" or "normalsexual" (a man who has a sexual preference for women). Regarding the latter category, Kertbeny held the view that the high sex drive of "heterosexuals" or "normalsexuals", which he claimed was stronger than that of homosexuals or bestialists, gave them an appetite for engaging in depraved excesses including incest, assaulting "male but especially female minors", and "behaving depravedly with corpses". Given the later shift in meaning to denote the biological naturalness and moral superiority of heterosexuality, the invention of the category of the heterosexual in the context of Kertbeny's promotion of gay rights is "one of sex history's grand ironies", as the historian Jonathan Ned Katz $(2007,53)$ has pointed out.

The term homosexuality was popularised in Germany by KrafftEbing and in the United Kingdom by Ellis. Charles Gilbert Chaddock, translator of Krafft-Ebing's Psychopathia Sexualis, is thus credited by the OED with having introduced the word "homosexuality" into the English language in 1892, a year after a medical publication had introduced the same term into French. "Lesbianism" first appeared in 1870, initially competing with the concepts of "tribadism" or "sapphism". The term homosexual also had early competitors. The German pioneering campaigner for sexual rights Karl Heinrich Ulrichs, for example, founded in I 862 the cult of "Uranism", a term borrowed from Plato's Symposium where "Uranian" or "heavenly" love of men for boys, attributed to the god Uranus, is praised. Against the backdrop of the romanticist 
rediscovery of Ancient Greece in Germany and Victorian England, other Uranian societies promoting male love and friendship sprang up in both countries, including in places like Oxford and Cambridge. Other terminological contenders were "homosexualist"; "pederast" (though referring to sex with boys, it also came to be used in reference to sex between men); "contrary sexual feeling"; "inverted sexual proclivity"; "sexual inversion";"intermediate sex";"third sex"; and "urnings" (again, from "Uranian love").

The concept of "sexual inversion" was particularly popular in the $19^{\text {th }}$ century. It expressed the widespread belief of the time that people with same-sex desires suffered from some kind of gender disorder and were really women in men's bodies, or vice versa (though the concept also covered a wider range of deviant gender behaviours such as men dressing up in women's clothes), or even possessing a third sex. Samesex desire was widely interpreted through the lens of gender, but disagreements raged over what the exact link between sexual identity and gender was. Whereas those defending the sexual inversion model argued that male homosexuals were "feminised", others held up the Greek paederastic model to argue that they were on the contrary especially masculine. The first movement for the rights of sexual minorities in the world emerged in Germany around the end of the $19^{\text {th }}$ century, following the criminalisation of homosexuality at a national scale, which had resulted from German unification. By 1902, divisions within the movement emerged over precisely this question, with Magnus Hirschfeld defending the third sex model whereas Benedict Friedländer argued that homosexuality was "the highest, most perfect evolutionary stage of gender differentiation", and that the male homosexual "inverted type" represented hypervirility, and possessed superior capacities for leadership and heroism than heterosexual men (Kosofski Sedgwick 1990).

In both competing models however, homosexual men and women were considered to be biologically separate types of persons, with specific personality traits, clothes, and bodies. They were thought to be particularly prevalent in large urban centres (which, in the context of the social disruptions resulting from accelerating urbanisation processes, were held to be particularly fertile breeding grounds for perversion, compared to the simple, "natural" life in the countryside). 
The biological model of sexuality saw homosexuals not as sinners or criminals, but as abnormal persons who were in need of a cure. Although some sexologists, including Ellis, saw homosexuality as inborn but not a disease, much of sexual science has been preoccupied with problematising and investigating these "marginal" sexualities, and thinking about how to "correct" the pathologies through therapy, as well as chemical and surgical interventions, including castration. Homosexuality was officially classified as a mental illness in the American Psychiatric Association's Diagnostic and Statistical Manual until 1973, and by the World Health Organisation until 1992. Similar psychiatric labels were abolished in the United Kingdom in 1994, in the Russian Federation in 1999, and by the Chinese Society of Psychiatry in 200I, after gay rights groups as well as dissenting psychiatrists argued that it was homophobia rather than homosexuality which was the problem.

\section{The cultural model of sexuality}

The biological paradigm remained dominant up to the 1980 s and is still an important theoretical influence on sex research today, especially given the current revival of evolutionary models of sexuality and genetic perspectives. However, the biological model of sexuality has come under attack from various quarters. The most decisive challenge to this model has resulted from the emergence of cultural perspectives across a range of disciplines in the social sciences and the humanities from the 1970s onwards. These new theoretical models reject the idea of sexuality as natural or biological, emphasising instead the cultural nature of sexual experience. Following Foucault's controversial but highly influential account of sexuality as a "historical apparatus" whose origins can be retraced to the $18^{\text {th }}$ century, drawing from his canonical History of Sexuality: An Introduction (1990), authors such as David Halperin in classics, Stephen Heath in literary criticism, and Jeffrey Weeks, Ken Plummer and numerous others in sociology have prominently argued for the need to understand sexuality as a historically and culturally situated domain of experience which is shaped by social relations of power.

Following this cultural model of sexuality, sexual identities are not merely the expression of natural instincts, but are social as well as 
political constructs. At the collective level, sexuality carries particular symbolic importance since it is through reproductive sexuality that the nation is biologically reproduced, which turns it into a concern of the state. As Michel Foucault $(2004,257)$ put it: "Sexuality has always been the site where the future of our species (and at the same time our truth as human subjects) are formed."2

The sociologist Nira Yuval-Davis (1997) has pointed out that collective preoccupations with the "purity of the race" tend to be crucially intertwined with the regulation of female sexuality. Politics around AIDS, for example, illustrate the complex intersections of sexuality with hierarchies around gender and "race", and its connections to notions of individual and collective "purity". More generally, concerns with higher levels of reproduction from "undesirable" categories of citizens such as Muslim immigrants have been openly articulated by politicians in countries such as France in the 1990s, echoing older Western worries about fertility levels in non-Western countries such as India or China. Female reproductive sexuality continues to constitute a particular policy concern of the state. For example, in 1970s America, an unspecified number of poor women were sterilised under the threat of withdrawal of welfare benefits, estimated to have impacted 100,000-150,000 women by the Federal Judge who put an end to the legality of such practices in a 1974 ruling. Numerous Mexican American women and an estimated $25 \%$ of American-Indian women had been sterilised without their consent or without their full knowledge by the mid-1970s. Doubts are frequently expressed as to the degree of current enforcement of the outlawing of sterilisation of welfare recipients; Republican politicians in the US renewed calls for forced sterilisation of "disorderly" categories such as crack mothers and other welfare recipients in the 1990s.

Issues such as AIDS, sex tourism, international trafficking of women and internet networks of paedophiles illustrate the global nature of politics of sexuality, as well as the resurgence of moral purity discourses and their political influence. Against the backdrop of the politics of sexuality as well as wider social and technological developments, sexuality has undergone profound changes over the past few decades. Modern sexual science has documented such everyday exper- 
iments. Somewhat ironically, the primary agents in the transformation of sexual truths and relations of power are those that the biological model (medicine and sexology) had constructed as marginal in relation to hegemonic male heterosexuality, such as women, homosexuals of both sexes, or transsexuals. In the process, social understandings of what sexuality means have opened up to a plurality of meanings in recent years. Whereas sexual liberation theorists such as Herbert Marcuse and Wilhelm Reich saw unrestrained sexual pleasure as crucial for the fulfilment of full human potential and happiness, competing understandings have portrayed sexuality as the site of risk, death, moral decay, commercial exploitation, male violence, political selfaffirmation, and destabilisation of identities.

Against this backdrop, the claim that heterosexuality, homosexuality, lesbianism and even sexuality itself were invented in the $19^{\text {th }}$ century does not only mean that the terms were invented in that period (although they were). More fundamentally, it means that the ways in which individuals - especially in the West - experience and make sense of their sexualities and identities in modernity are heavily shaped by the three core elements associated with the conceptual apparatus of sexuality, in particular the notion of "natural" sexual instinct, the assumed biological basis for gender differences, and the notion of sexual identity.

Female sexuality has been subjected to particular scientific and moral scrutiny throughout modernity. It has also constituted a central concern in feminist struggles. Female activists from mostly upper middleclass backgrounds played important roles in the numerous social movements promoting greater moral purity and "social hygiene" which emerged from both the political left and conservative and religious organisations across the Western world from the late $19^{\text {th }}$ century onwards. Campaigns against prostitution called for an end to the "white slavery", which forced innocent, impoverished young workingclass girls into sexual exploitation by unscrupulous middle-class men. The moralist view was that prostitution was a vice; it was also considered a major public health problem. Prostitutes were seen as the main vehicles of the contamination of men with venereal diseases such as gonorrhoea and syphilis, echoing traditional associations in Western culture between the female body and disease.

Venereal disease itself came to be culturally represented as female in the Modern Age:"Dame Syphilis" as the French called it. Syphilis had 
appeared in Europe from the late $15^{\text {th }}$ century, possibly carried by sailors returning from the Americas, and led to a great epidemic across the continent. Collective anxieties about syphilis portrayed it as coming from the "outside", in particular from foreigners, reflecting wider cultural meanings around sexual disease that tended to see the healthy, male bodies of the nation as polluted by diseased female and foreign bodies.

Driven by fears that venereal disease would make male bodies too weak for military purposes, many nation-states started to regulate prostitution in the $19^{\text {th }}$ century in order to prevent and limit the spread of sexual infections. No efforts were made to prevent customers from contaminating prostitutes, but the latter were targeted with compulsory medical inspection, and, if contamination was diagnosed, incarceration and forced hospital treatment. Folk beliefs circulated in the $19^{\text {th }}$ century that intercourse with a child virgin could cure venereal disease, and brothels catered to this particular sexual demand. More generally, child prostitution was widespread across Europe and elsewhere. In 1904, the first International Agreement for the Suppression of the White Slave Traffic was agreed upon, giving rise to a gradual process of legal prohibition of brothels across most Western countries.

\section{Male sexuality and power}

From a theoretical point of view, it is worth noting that feminist struggles against prostitution and pornography, in the $19^{\text {th }}$ century as well as in more recent decades, portrayed male sexuality routinely as intrinsically violent. The prominent second-wave feminist Andrea Dworkin (1987) famously extended the analysis to intercourse itself, arguing that the sexual domination which she saw as central to pornography constitutes a basic feature of the ways in which men and women experience intercourse in patriarchal society. Dworkin's views echoed statements made a few years earlier by the radical Leeds Feminist Revolutionary Group who declared in 1981: "Only in the system of oppression that is male supremacy does the oppressor actually invade and colonise the interior of the body of the oppressed. (...) Penetration is an act of great symbolic significance by which the oppressor enters the body of the oppressed". 
Though by no means a unified field, feminist theories of sexuality primarily problematised female sexuality and its repression, while treating male sexuality as implicitly unproblematic. Portrayals of male sexuality tended to echo biological models of sexuality in taking for granted its naturally aggressive, triumphant and, at times, violent nature. In contrast, poststructuralist, postcolonial and postmodern theories of gender emerged from the 1980s, which rejected perceived simplistic binary oppositions between men-the-oppressors and women- the-passive-victims as politically mobilising but conceptually unhelpful. Feminist critics such as Lynne Segal, joined by theorists of masculinity - a field which has greatly expanded since the 1990s argued that it would be a mistake to conclude that this is also the way in which individual men experience sexuality. As Segal $(1997,212)$ has pointed out, "for many men it is precisely through sex that they experience their greatest uncertainties, dependence and deference in relation to women - in stark contrast, quite often, with their experience of authority and independence in the public world".

The theoretical conflicts run deep here, because they do not only concern differences about political strategies regarding commercial sex, but also involve fundamentally different ways of thinking about sexuality and its links to relations of power between the genders. The connections between sexuality and power are all the more important because our relation to ourselves as sexual beings constitutes such a central component of modern identity, as Foucault emphasised. For Foucault $(1990,15)$, sexuality is "an especially dense transfer point" of power relations; a prime target of modern relations of power and fundamental to processes of societal disciplinarisation of "disorderly" populations in health and demographic policies, for example.A similar point is made by the social theorist Anthony Giddens, who argues:"Somehow... sexuality functions as a malleable feature of self, a prime connecting point between body, self-identity, and social norms "(1992, 15). The two authors disagree, however, on the political implications of the centrality of sexuality to modern self-identity (see also Mottier 1998). Whereas for Foucault, sexuality is a prime target of modern relations of power and fundamental to processes of societal disciplinarisation of "disorderly" populations, Giddens identifies the spread of the "pure" relationship over the past few decades as a positive phenomenon; by "pure" relationships he means to denote a type of relationship which, in a 
social context where women's economic dependency towards men has lessened and exit options such as divorce have become accessible on demand, exists for its own sake. Though more fragile than traditional marriage which was propped up more firmly by wider social institutions, the pure relationship involves transformations of intimacy which contribute towards a democratisation of the private as well as the public sphere. Concentrating on heterosexual relationships, Giddens, similar to the German sociologists Beck and Beck-Gernsheim, see women as the vanguard of more equal understandings of sexuality and intimacy. In their view, transformations of male sexuality are largely a result of female agency and of women's struggles to change their lives. As Beck and Beck-Gernsheim (1995, I53) put it, "men's liberation is a passive affair". Men, they add, "seem to engage in self-liberation as spectators".

Certainly, relations of power between men and women have shifted dramatically over the past few decades, as have normative models of femininity and masculinity. Whereas male sexuality has been frequently theorised as inherently violent, as we have seen, alternative accounts have emphasised the passivity and vulnerability of male (hetero)sexual experience against the backdrop of a wider "crisis of masculinity". Similarly, recent controversies over the potency drug Viagra could be read in different ways: the speed of its availability on the market could be seen as a sign of the triumph of male wishes or, alternatively, as further contributing to the myth (and psychological pressure) of unproblematic male sexual performance. In terms of intersections between gender and sexuality, analyses have currently come full circle, from the pathologisation of female sexuality and taken-for-grantedness of male heterosexuality as the norm within sexual science and medicine, to greater problematisation of male sexual experience, reminding us, in the words of the political theorist Terrell Carver (1996), that "gender is not a synonym for women".

Current theoretical conflicts around the links between sexuality and gender power also signal the need to further explore the intersections between sexuality, gender and "race". For example, as the African-American author bell hooks has argued, sexual violence such as rape has historically played a particularly important role for Black women, as a central element in the system of slavery, and continues to have an impact on contemporary sexualised portrayals and sexual fantasies about Black women. Glossing over such differences in the name 
of universal male oppression is neither analytically accurate, nor politically satisfactory, I believe. Consequently, it seems to me that there is an urgent need in development studies for an in-depth understanding of the ways in which sexual pleasures, dangers, and health risks, are shaped by complex relations of power around gender, "race", and social class (one could add age, mental illness, and physical disabilities). I would therefore like to conclude this chapter by calling for more differentiated analyses of male and female sexuality, which take into account their complex intersections with "race", social class, and other identity categories.

\section{References}

Beck, U. and E. Beck-Gernsheim. 1995. The normal chaos of love. Cambridge: Polity Press.

Carver,T. 1996. Gender is not a synonym for women. Boulder, CO: Lynne Rienner.

Carver, T. and V. Mottier (eds). 1998. Politics of sexuality. Identity, Gender, citizenship. London: Routledge.

Dworkin, A. 1997[1987]. Intercourse. New York: Simon \& Schuster.

Forel,A. 1908[1906]. The Sexual question. London:William Heinemann.

Foucault, M. 1990[1976]. The history of sexuality, Vol. I: An introduction. Harmondsworth: Penguin.

Foucault, M. 2004. Non au sexe roi. In Dits et écrits 1954-1988 par Michel Foucault. Vol. 3. (Eds.) D. Defert and F. Ewald. 256-69. Paris: Gallimard.

Geddes, P. and J. A.Thomson. 1914. Sex. London: Home Universal Library.

Giddens, A. 1992. The Transformation of intimacy: sexuality, love and eroticism in modern societies. Cambridge: Polity Press.

Halperin, D. M. 1990. One hundred years of homosexuality and other essays on Greek love. New York: Routledge.

Heath, S. 1982. The Sexual fix. Houndmills: MacMillan.

Katz, J. N. 2007. The Invention of heterosexuality. Chicago: University of Chicago Press.

King, H. 1998. Hippocrates's woman. Reading the female body in Ancient Greece. London: Routledge.

Kosofski Sedgwick, E. 1990. Epistemology of the closet. Berkeley: University of California Press.

Krafft-Ebing, R. Von. 1998 [1886]. Psychopathia Sexualis. New York: Arcade Publishing.

Laqueur, T. 1990. Making sex. Body and gender from the Greeks to Freud. Harvard: Harvard University Press.

Leeds Revolutionary Feminist Group, 198I. Love thy enemy? The debate between heterosexual feminism and political lesbianism. London: Onlywomenpress. 
Marcus, S. 1964. The other Victorians. A study of sexuality and pornography in mid-nineteenth-century England. New York: Basic Books.

Mottier, V. 1998. Sexuality and sexology: Michel Foucault. In Politics of sexuality. Identity, gender, citizenship. (Eds.) T. Carver and V. Mottier. II3-I23. London: Routledge.

Mottier,V. 2008. Sexuality: a very short introduction. Oxford: Oxford University Press. Péladan, J. 2006[1884]. Le vice suprême. Lyon: Éditions Palimpseste.

Segal, L. 1997. Slow motion, changing masculinities, changing men. London: Virago (revised edition).

Weeks, J. 1985. Sexuality and its discontents. Meanings, myths and modern sexualities. London: Routledge \& Kegan Paul.

Yuval-Davis, N. 1997. Gender and nation. London: Sage. 


\section{Through the looking-glass : sexual-economic exchange}

\section{Paola Tabet*}

My specific object of research is sexual-economic exchange, or in other words the relations between men and women involving some kind of compensation given by the man for the sexual services of a woman'.

To clarify from the onset, my object is not what people would generally consider when they read or hear this definition. I am not talking primarily about "prostitutes" or "whores". A first question to be asked in fact is:What is a whore? Is there any clear and universally accepted definition of who can be termed a whore? And here comes the first surprise: when we look across cultures and societies, when we consider, say, European history, we see there is no agreement as to what defines a whore. Indeed, there is no universally held definition. It is not defined for instance in terms of "the many and the money". A culture may have a perfectly legitimated ritual whereby a newly-wed bride must sleep with the young men in her husband's age group on her first night of marriage, without being considered a whore in her own society. But on the other hand, this case is chosen by Encyclopaedia Cattolica (1953) as an example of prostitution thus

Anthropologist, University of Calabria (Italy).

I For a fuller discussion of the points presented here, see Tabet (2004).

Tabet, P. 2012. Through the looking-glass: sexual-economic exchange. In Chic, chèque, choc. Transactions autour des corps et stratégies amoureuses contemporaines. 39-5I. Actes des colloques genre et développement. Berne: DDC-Commission suisse pour I'UNESCO; Genève: IHEID. 
including the traditional lending of a wife to a guest in Eskimo societies. We clearly have here a situation in which what is normal and legitimate in one society and in one culture, is considered wrong and illegitimate in another.

There are societies, on the other hand, where women are supposed to give sex in exchange for material benefits, where for instance a woman is set to marry several men so that her father may receive bride-wealth from each husband. A wife may also be allowed to sleep with her husband's partners as well as members of his family, but these same women would be in serious trouble should they become involved with a man outside their husband's or father's choice set: they would then be stigmatised as promiscuous, or whores. So neither the multiplicity of partners that we tend to consider as a necessary element for this definition, nor receiving money (i.e. the exchange of money or other objects or property for sexual services) defines in all cultures and in all times the whore or prostitute, nor necessarily sets her apart from other women. Ethnologists and historians have made this quite clear.

Maurice Bloch $(1989,166)$, commenting on the cultural differences in meanings attached to money for sex, stresses this point:

In Europe the linking of monetary exchange and sexual or familial exchange is seen as either typically immoral or as a source of humour and dissonance. By contrast, in Madagascar the need to keep the two areas separate is not present. The right thing for a man to do is to give his lover a present of money or goods after sexual intercourse. This applies not only to pre-marital or extra-marital sex, but also to marital relations, though on a less regular basis.

Consider then this case drawn from European history. Ruth Mazo Karras who has studied "common women" in Medieval England states: "The modern Western notion of a prostitute as a woman who takes money for sex is a creation of particular understandings of sexuality and money. It is not a category automatically meaningful in any other culture" $(1996,10)$. And indeed "late medieval English culture had no conceptual category reserved for women who engaged in sex for money" (I3I). In fact economic transactions are not a peculiar specific feature of prostitution: "A women was not considered a whore because of or on the basis of economic exchange as this exchange concerned all women" (emphasis added). 
What is more: "Medieval English culture assumed that all women ought to belong to some man. [...] Any woman who was not a wife, a daughter (directly under her father's control) or a servant [...] was suspect, and impugning her morality was one way of keeping her in line" (I35). She was considered to be "out of control", "out of place" and for this reason she could be considered a "whore". And the menace of the whore label or "whore stigma", that G. Pheterson (1996, 65) considers a gender stigma, was used in Medieval England as in so many other situations (Pheterson 1996; Tabet 1987) to keep her under control. The same holds for France before the French Revolution, where taking money for sex was not always the qualifying element even in juridical definitions of prostitution (Benabou 1987).

What in fact is at stake in the definitions of a woman as whore is not a specific concrete behaviour: situations that comprise sexual-economic exchange, as well as others that do not, may both be considered illegitimate and stigmatised. There is actually no universally held definition. The only universal element that encompasses the different definitions is something else: it is the transgression of the rules concerning the property of women's bodies, the rules establishing who has the right to control women and decide what use is to be made of women's bodies in that specific society (Tabet 1987; 2004). Transgressing these rules entails punishment. And one punishment for women is being stigmatised as a whore. And indeed: "The menace of the whore stigma acts as a whip holding female humanity in a state of pure subordination. Until that whip loses its sting the liberation of women will be in check" (Pheterson 1996, 89).

So we have to leave aside our common sense ideas about prostitution and turn to this different object of research: the conceptual field defined by all relations of exchange of sexuality between men and women, whether they are transgressive or not, in which on the man's side there is some form of payment in exchange for some form of sexual service from a woman². This field covers "illegitimate" situations (as with prostitution in most societies) as well as institutions that are

2 Though of great interest, I will not deal here with relations where the economic exchange in gifts or money etc. goes in the other direction, from the woman to the man, as in the example of Barbados "beach boys" and women from wealthier countries studied by Phillips (2002). Nor will I deal with sexualeconomic exchange in homosexual relations. 
central to a society like marriage (in whatever form it may take in different societies) - and here one element of the exchange may be not only a financial compensation but also legitimacy and name or social prestige.

What must be stressed is that there is a continuum of forms of sexual service given by women and not a dichotomy between marriage and the other relations that imply sexual-economic exchange. In any situation where the woman is giving sexual service and the man is paying, he is giving a compensation that can vary in size and kind: whether it involves money, food, clothes, housing, access to jobs or generally access to resources (for instance, access to farming land in societies where agriculture is the economic basis, and women's access to land depends on their marriage). For "sex is women's work" they say in Niger, "a woman's sex is her land"; "it is her capital", they say in many other places 3 . Italian prostitutes jokingly say: "We are sitting on our capital". And how much a man cares about the relation is assumed to be shown in the amount he gives, that is to say, how well he treats the woman. So in Ghana, for example, the amount of "chop money" or money for food that a woman receives shows how well a husband or lover supports her and is a frequent cause of domestic trouble (Abu 1983). Clearly, to understand the prevalence of sexual-economic exchange, we must keep in mind what the sexual division of labour means in all known pre-industrial societies (Tabet 1979; 1982). We have to consider the enormous difference between men's and women's access to resources, and also the well known fact that over $90 \%$ of the world's resources, capital, etc., are in men's hands, while women do far more than half of the working hours (but earn less than one per cent of the wages paid in the whole world). And remember too that, also in industrialized countries, salaries for men and women and access to jobs are still unequal.

There are several aspects of sexual-economic exchange I want to deal with here. It is important to keep in mind, as I said, that we do not have a dichotomy between marriage and prostitution but that they are placed in a continuum with variations at almost every level. I'll briefly enumerate some of these variations:

3 In Haiti, for another example:"Women's sex is explicitly perceived to have economic exchange value, to be her "assets ". Women [...] may refer to their genitals as tè $m$ (my land) or byen' $m$ (my assets)" (de Zalduondo and Bernard 1995). 
I. Relations differ in time length along a continuum going from lifelong marriage at one end, to forms of institutionalised "temporary marriage" ", to many kinds of relations varying in time length and form of negotiation (more or less explicit) such as the relations with "mistresses" or "kept women", to - at the other end of the continuum - the few-minute stint as with some forms of prostitution.

2. The continuum also concerns the women involved in the exchange. Instead of accepting as a given the currently held absolute separation or division of women into wives and whores, it is possible to show a continuum ranging from marriage to the modern forms of sex work. Women in fact may alternate in their lifetime between types of sexual-economic relations, going from marriage to having steady boyfriends, more or less steady clients, and "sugar daddies" or boyfriends who pay with gifts or fees. It is a situation well known and stressed by sociologists working in African cities (illustrated through recent research in Mali, presented in this conference by Françoise Grange Omokaro et Fenneke Reysoo, as well as in Morocco presented here by Mériam Cheikh). Renée Pittin $(1979 ; 1983)$ and others (Echard 1985) have studied this life pattern, which is particularly clear in the case of the "free women", "femmes libres" or "karuwai" (to use the Hausa name) of Niger and Nigeria, who alternate periods of marriage and periods of sexual service to one or more men upon whose "gifts" they depend. As Renée Pittin notes, giving sexual service in return for an economic compensation does not distinguish a "free woman" from a wife: in fact "any woman expects to benefit economically from her man be he husband or suitor or lover... Women do not bestow their bodies, their time, and their lives gratis; they expect some recompense" (Pittin 1979). I found this same pattern in my fieldwork in Niger. Moving between forms of sexual-economic exchange has been noted among working class women in $19^{\text {th }}$ century London in the ground-breaking work of Judy Walkowitz ${ }^{5}$ (1980). Peiss (1986) and Stansell (1987) describe analogous situations in New York.

4 As in Ethiopia, for instance, where the temporary wife has an agreed-upon fixed salary and can sue the man if she is not paid. The children born from this marriage are considered legitimate and recognised by the father.

5 In the case of Great Britain at the end of the 19th century, Walkowitz has clearly shown how working class women who gave paid sexual services out of 
3. There is a continuum also in the kinds of services women give: from a global service (as with marriage) implying anything from domestic labour (Delphy 1998; 200I), reproduction (Tabet 1985; 1998), care and relational service and sexual service, to situations where only sexual service is exchanged. But even overt sex work can be far from the idea of just a service within a fixed time period, at a fixed fee and where specific sexual services are explicitly negotiated. Here again we are faced with a great variety of situations. Some forms of prostitution may in fact include domestic labour, as well as some form of relational labour. White's study on prostitution in Nairobi between 1909 and 1950 (White 1990) gives a rich documentation of this and other forms: in one form of sex work, women - called malayas - did not give only sexual service, they cooked food for their clients, prepared their bath water and could even offer a place to sleep; they would also receive a client just for a chat and a cup of tea. But other malayas in more recent years (the 1970s) tend to refuse this kind of service:"I love it [sex] with a man I am attracted to, but I never let a man stay in my room until daylight. If they stay, they start wanting tea, and then food, and then before you know it, you are washing his clothes. I don't have time" (Nelson 1977, I54, emphasis added). And indeed, though malayas consider their work, even the very short sex relation called "quick service", as a sort of mini-marriage, one of them clearly spelled out its limits:"a malaya is a wife that doesn't clean for her husband" (Nelson 1977, 17).

4. Negotiation is an absolutely basic point in this continuum as here we are dealing not only with the possibility that women can decide on the type of compensation they receive, but also the type of work and work conditions: the possibility of fixing an amount of work time as well as the scope of tasks and payment in fact defines the status of a relation, whether it is a relation of personal dependence and subordination akin to relations of slavery or serfdom ${ }^{6}$, or a contractual relation. And here again we have a whole range of situations: from the frequent impossibility or at

marriage for some period of their lives, were ghettoised, separated from their class and forced to remain in prostitution for longer time periods by laws against venereal deceases. 
least difficulty for wives to negotiate and quantify their work or services, whether they be sexual, domestic or procreative, as with the relation of marriage (especially marriage for life), to situations where you have explicit negotiation. Negotiation can be done in a semi-covert way, using seduction as a means to obtain things, or in explicit ways by fixing a price (and time period) for a specific service, as with sex work assumed as such. Forms of compensation also vary, from gifts or up-keep left to the man's will, to fees contractually decided upon.

I am talking about a continuum but does it involve any breaking points? And where? Most importantly, what differences are crucial to women? How do women themselves make their decisions and choices? When and how can they and do they decide about their lives? As important as this point may be, I can only call your attention to it. Women's choices, women's forms of resistance, in Africa and elsewhere, can be noted when they leave their marriages, for instance, particularly in the case of forced marriages. Women might then migrate to cities where they seek out ways of surviving in order to gain some sense of personal and economic autonomy, and may live by giving sexual services beyond the bonds of marriage. Women's migrations, with the purpose of escaping unbearable subordination, forced sex and forced pregnancies, "too much work - as one 'free woman' in Niamey told me - and a husband that beats" for "you can't keep men from beating" (Morokvasic 1986), have been seen as an alternative form of class struggle.

Let us turn then to an essential question: what place does sexualeconomic exchange have in the social relations between men and women? My interest and my research on the exchange of sexuality began more than two decades ago (Tabet 1987), after reading Malinowski's well known book The sexual lives of savages in NorthWestern Melanesia (1929). Malinowski shows that the Trobrianders are very free in their sexual habits starting from when they are children. In

6 A relation of personal dependence, of private appropriation of women or what Colette Guillaumin calls "sexage" (Guillaumin 1992; 1995). Guillaumin gives a special importance to measures (or absence thereof) as a central element in defining the relation. 
all sexual relationships, women are "paid", that is to say they receive "gifts". This is something puzzling to Malinowski, something he can't explain, that he in fact considers as quite "illogical". "Considering the great freedom of women", says Malinowski, "and their equality with men in all matters, especially that of sex, and considering that the natives fully realize that women are as inclined to intercourse as men, one would expect the sexual relation to be regarded as an exchange of services in itself reciprocal". But no: "Custom, arbitrary and inconsequent, here as elsewhere, decrees that it is a service from women to men, and men have to pay". And indeed "the gift is an essential part of the transaction" to the point that "in the course of every love affair the man has constantly to give small presents to the woman". What's more, this "need of one-sided payment" is "self-evident" for the Trobrianders as they consider that "sexual intercourse, even where there is mutual attachment, is a service rendered by the female to the male. As such it has to be repaid in accordance with the rule of reciprocity, or give-andtake, which pervades tribal life". Based on this rule, any service received (as the building of a canoe for example or magic) has to be repaid, and the payment is called mapula, a word used to describe "equivalence" or "repayment". The gifts or payments (called buwa), given to women in all sexual relations vary from tiny presents given to girls by little boys, to more substantial presents given from time to time to lovers in longer relations, or to presents a husband gives his wife "for the permanent sexual accommodation" she offers him. And Malinowski insists: "This rule [giving a regular 'reward for sexual favours'] is by no means logical or self-evident”. (Malinowski 1929, 319-321).

The question Malinowski raises makes sense: why is women's role in sex considered a service if women and men are equal? If Malinowski's premise on equality is correct, then the payment is not "logical". But it is easy to show, using Malinowski's very data, that the relation is not equal in many aspects (starting with who has the right to choose the partner). I would say that Malinowski does not take his own ethnological data sufficiently into account; it is quite clear that the islanders know more about their gender relations and the power relations between the sexes than he does.

What seems to be a problem for Malinowski is not at all a problem for Marcel Mauss, nor for Claude Lévi-Strauss. Quite the contrary! 
Mauss (1950) considers that a very important contribution of Malinowski, a contribution that "throws a brilliant light on all sexual relations in all mankind", has been to "liken the mapula, the 'constant' payment a man gives to his wife, to a sort of salary for the sexual service given" (268), or as Mauss writes elsewhere to "a sort of salary-gift for the service given by the wife when she lends what the Coran still calls the field" (190). This is "a great discovery that sheds light on all the economic and juridical relations between the sexes in marriage" (190, emphasis added).

For Lévi-Strauss (1967), Malinowski’s “anomaly”, i.e, the payment for women's sexual acts (the buwa) can be explained by situating it in a larger social context. Placed in the context of the general theory on the exchange of women, Lévi-Strauss argues that what Malinowski considered to be an anomaly becomes self-evident: "The total relationship of exchange which constitutes marriage is not established between a man and a woman, but between two groups of men", and "the woman figures only as one of the objects of exchange, not as one of the partners". Considering this global relation ${ }^{7}$, the allegedly illogical situation raised by Malinowski - that for Trobrianders the sexual relation is a service from women to men, a service men have to pay - can be explained quite simply: the relation cannot be reciprocal as women are not partners but objects of exchange. There is one area where women can have a margin of authority, "a category that depends principally upon her good will: personal services, be they domestic or sexual" (Lévi-Strauss 1967: I34-135). So all is clear.There being no reciprocity, sex, as Lévi-Strauss himself states, is a service the woman gives (depending upon her good will!).

So here we have two renowned anthropologists who define unambiguously - just as an obvious fact - women's sexual acts as services for which clearly men pay. And, allow me to emphasize, they are talking about marriage, not about prostitution. Clearly, what so often tends to be hidden or obfuscated for those who are dominated is revealed as self-evident and quite obvious for those on the other side ${ }^{8}$.

7 See Rubin's critique (Rubin 1975).

8 For the different levels of knowledge dominants and dominated tend to have about the mechanisms of domination (specifically between men and women) see Mathieu (1985; 1991; 1999). 
But if sexual-economic exchange is the general pattern of men's and women's relations, what does this mean for women? And how is it linked to other aspects of male-female relations? And specifically what does sexual-economic exchange mean for the construction of women's (and men's) sexuality? How is women's sexuality conditioned, we could say built, into becoming a service? How do you make a woman? Because as Simone de Beauvoir says, "On ne naît pas femme" (or one is not born a woman). These questions are too complex to deal with in a short presentation. How such conditioning plays out in different societies and in different historical periods needs specific research, but I want to provide here one example from a life story that illustrates some of its possible elements, that we can first summarize.

First of all, let us consider the link between the sexual division of labour, the differential access of men and women to basic resources, and women's subordination. Add to that the pressure and cultural conditioning starting from childhood that forces girls and later women to submit to male domination, and specifically to their husband's requests. And third, how necessity and submission can be turned into gratification.

The story of Nisa, a! Kung, woman of the Kalahari desert in Namibia can be used as an example of how these elements play out (Shostak 1983). The!Kung are a population of hunters and gatherers', with a strict division of labour between the sexes: women do the gathering and men the hunting; use of hunting tools is forbidden to women, making women dependent on men for this most precious form of protein food, and relegating them to the difficult task of collecting roots and meagre vegetables from the desert, forming the staple food of the!Kung. During Nisa's childhood, her father tells her that a husband is like a father, that he kills animals and gives her meat to eat, that the wife depends on him. Like other!Kung girls, Nisa is forced to marry very young, before puberty, still a child and very much feeling like one. (Nisa's own daughter, years later, will die from having her neck broken: the husband had tried to rape her just after her first menstruation and had violently thrown her to the ground).

9 The present tense is used here to convey the time of Nisa's childhood, as some!Kung were still living at that time and during Shostak's field work in settlers farms as farm labourers. 
The whole family continuously tries to persuade Nisa to accept her husband. Her mother says: "Now, take this man as your husband, this strong man who will get food, for you and for me to eat. Is your father the only one who can find food? A husband kills things and gives them to you; a husband gets meat that is food for you to eat". Finally, Nisa leaves the husband she never accepted, but is forced to marry again and goes through several trial marriages. She tries to run away, hides in the bush, but is found and taken back. Though at first the!Kung view such actions with some tolerance, as the girl becomes older societal pressures become stronger, including threats of violence, to oblige her to conform. And the whole family goes on insisting:"A man is not something that kills you, he is someone that marries you, who becomes like your father or your older brother. He kills animals and gives you things to eat." Nisa is forced to have sex against her will. She makes herself a sort of protective device in the form of a leather belt, to avoid having sex, but her husband manages to rape her. And, she says, she finally "understands": "When Tashay wanted to lie with me I no longer refused... We lived and when he wanted me, I didn't refuse... I thought: 'Why had I been so concerned about my genitals? They aren't that important, after all. So why was I refusing them?'”. So Nisa submits to the sexual conditioning imposed on her. She accepts as a priority what her husband wants and she begins to love him.

And eventually she also manages to get something for herself. Nisa talks about enjoying sex and having lovers, and also how she enjoys the gifts she receives from them, whether food, beads or money. When a husband leaves for some time, Nisa says, a woman sees her lovers: "If one of her lovers lives in a village nearby and an animal is killed, he'll cut some meat and bring it to her... He'll sit with her, cooking it until the broth is rich and heavy. She will drink it and her heart will be happy. She'll think: 'Oh my husband has just left and here I am, drinking this wonderful broth'."

Gifts from lovers are sought after and are clearly a source of selfgratification and pride. A woman, Nisa tells the anthropologist, "should have lovers wherever she goes... Because each one gives her something. She gathers from one man one thing, from another something else, and from another, yet something else. It is as though her genitals were worth money - Pounds! Rands! Shillings! (Nisa laughs)”.

We have come full circle. 


\section{References}

Abu, K. 1983. The separateness of spouses: conjugal resources in an Ashanti town. In (Ed.) C. Oppong. Female and male in West Africa. London:Allen and Unwin.

Benabou, E. 1987. La prostitution et la police des mœurs au XVIII' siècle. Paris: Perrin.

Bloch, M. 1989. The symbolism of money in Imerina. In Money and the morality of exchange. J. Parry and M. Bloch. 165-190. Cambridge, New York: Cambridge University Press.

Delphy, C. 1998. L'Ennemi principal. Vol. I. Economie politique du patriarcat. Paris: Syllepse.

Delphy, C. 200I. L'Ennemi principal.Vol. 2. Penser le genre. Paris: Syllepse.

De Zalduondo, B. and J. M. Bernard. 1995. Meanings and consequences of sexualeconomic exchange: gender, poverty and sexual risk behavior in urban Haiti. In Conceiving sexuality: approaches to sex research in a postmodern world. (Eds.) R. G. Parker and J. H. Gagnon. I57-I80. New York and London: Routledge.

Echard, N. 1985. Même la viande est vendue avec le sang. De la sexualité des femmes, un exemple. In L'Arraisonnement des femmes. Essais en anthropologie des sexes. (Ed.) N. -C. Mathieu. 37-60. Paris : Editions E.H.E.S.S.

Guillaumin, C. 1992. Sexe, race et pratique du pouvoir. L'idée de nature. Paris: Côtéfemmes.

- 1995. Racism, sexism, power and ideology. London, New York: Routledge.

Karras, R. M. 1996. Common women. Prostitution and sexuality in medieval England. Oxford: Oxford University Press.

Lévi-Strauss, C. 1967. Les structures élémentaires de la parenté. Paris, La Haye: Mouton \& Co.

Malinowski, B. 1922. Argonauts of the Western Pacific. London: Routledge and Kegan Paul.

— 1929. The sexual life of savages in North-Western Melanesia. New York: Harcourt, Brace and World.

Mathieu, N.-C. (Dir.). 1985. L’Arraisonnement des femmes. Essais en anthropologie des sexes. Paris: Editions E.H.E.S.S.

— 1991. L'anatomie politique. Catégorisations et idéologies du sexe. Paris: Côtéfemmes.

— 1999. Bourdieu ou le pouvoir auto-hypnotique de la domination masculine. Les Temps Modernes. 604 (mai, juin, juillet): 286-324.

Mauss, M. 1950. Essai sur le don. Forme et raison de l'échange dans les sociétés archaïques. Paris: P.U.F.

Morokvasic, M. 1986. Émigration des femmes: suivre, fuir ou lutter. Nouvelles Questions féministes. 13:65-75.

Nelson, N. 1977. Dependence and independence: female household heads in Mathare Valley.A squatter community in Nairobi, Kenya. Ph.D diss., University of London. 
Peiss, K. 1986. Cheap amusements. Working women and leisure in turn-of-the-century New York. Philadelphia:Temple University Press.

Pheterson, G. 1996. The prostitution prism. Amsterdam: Amsterdam University Press.

Phillips, J.L. 2002. The beach boys of Barbados, post-colonial entrepreneurs. In Transnational prostitution: changing global patterns. (Eds.) S. Thorbek and B. Pattanaik. 42-56. London and New York: Zed Books.

Pittin, R. 1979. Marriage and alternative strategies: carrier patterns of Hausa women in Katsina City. Ph.D diss., University of London, S.O.A.S.

— 1983. Houses of women: a focus on alternative life-styles in Katsina City. In Female and male in West Africa. (Ed.) C. Oppong. 291-302. London: Georg Allen and Unwin.

Rubin, G. 1975. The traffic in women: notes on the "Political Economy of Sex". In Toward an anthropology of women. (Ed.) R.R. Reiter. I57-2 I0. New York: Monthly Review Press.

Shostak, M. 1983. Nisa: The life and words of a!Kung woman. New York: Vintage Books, Random House.

Stansell, C. 1987. City of women: sex and class in New York, I789-1860. Urbana and Chicago: University of Illinois Press.

Tabet, P. 1979. Les mains, les outils, les armes. L'Homme XIX (3-4): 5-6I.

—. 1985. Fertilité naturelle, reproduction forcée. In L'arraisonnement des femmes. Essais en anthropologie des sexes (Dir.) N.-C. Mathieu. 6I-I46. Paris: Editions E.H.E.S.S.

—. 1987. Du don au tarif. Les relations sexuelles impliquant un compensation. Les Temps Modernes. 490: I-53

—. 1998. La construction sociale de l'inégalité des sexes. Des outils et des corps. Paris: L'Harmattan (Bibliothèque du féminisme).

—. 2004. La Grande Arnaque. Sexualité des femmes et échange économico-sexuel. Paris: L'Harmattan (Bibliothèque du féminisme).

—. 2004. La Grande beffa. Sessualità delle donne e scambio sessuo-economico. Soveria Mannelli: Rubbettino.

Walkowitz, J. 1980. Prostitution and Victorian society. Women, class, and the state. Cambridge: Cambridge University Press.

White, L. 1990. The comforts of home. Prostitution in colonial Nairobi. Chicago and London: University of Chicago Press. 



\title{
Seductive consumption. The influence of pornography on marital sexual demands in Tajikistan
}

\author{
Colette Harris*
}

\section{Introduction}

\section{Sex and gender}

Human sexual behaviour is to a very large extent informed by gender norms that prescribe, and indeed proscribe, certain types of conduct. That this occurs as much in the privacy of the bedroom as in more public settings is shown by the enormous pressures towards appropriate performance that exist even among more permissive societies such as those of north western Europe, as the bombardment of email spam regarding penis size and erection capabilities suggests.

In Tajikistan, pressures to conform to a considerably narrower set of gender ideals have been seriously constraining even for the most emancipated. For those who feel they have little choice but to conform - a category into which the vast majority of my acquaintances fall - the options are few. Failure to perform correctly, whether in bed or out of bed, can result in serious social penalties that may far outweigh personal preferences (Harris 2004).

Anthropologist, University of East Anglia, Colette.Harris@uea.ac.uk

Harris, C. 2012. Seductive consumption. The influence of pornography on marital sexual demands in Tajikistan. In Chic, chèque, choc. Transactions autour des corps et stratégies amoureuses contemporaines. 53-70. Actes des colloques genre et développement. Berne: DDC-Commission suisse pour I'UNESCO; Genève: IHEID. 
While it appears that men enjoy more freedoms than women, in many ways this is illusory. They may have greater physical and sexual mobility but the pressures to conform to gender norms are no less intense, as this paper will demonstrate.

\section{The background}

Until 199I, Tajikistan was one of fifteen union republics of the USSR, a setting in which public discussion on sex had been banned for decades (Kon 1995). Sex is still not easily discussed in former Soviet Central Asia, despite the arrival of hard and soft forms of pornographic videos from Russia and blatant sexual displays in television programmes broadcasted even during prime-time viewing hours (Goldschmidt 1999).

When I first arrived in Tajikistan in 1994, members of a women's movement warned me off the subject of sex on the grounds that the subject matter was completely unimportant and only we, Western feminists, thought otherwise. Despite this attitude coming from educated women, large numbers of less educated Tajiks of both sexes seemed eager to discuss the sexual issues troubling them (see Harris 2004 ; 2005a; 2005b).

This paper is based on work I carried out in Tajikistan from 1994 until $200 \mathrm{I}$, first as a researcher and later as a development agent. In 1997, I founded an NGO to provide grassroots transformative education in rural communities. Eventually, our work expanded to include sex education and the training of sex-education teachers for schools, as well as sexological training for psycho-social counsellors and medical practitioners.

Placing this context in relation to the theme of this volume, it is hard to think of Tajikistan as having much to do with chic, although there are slight manifestations of it in central Dushanbe. Chèque has certainly become a very important issue in these post-socialist times and choc unfortunately even more so, although in perhaps a different sense from that intended by the editors of this volume. The end of the post-Soviet period in Tajikistan produced a significant shock, not only because it ended the still high levels of social and economic stability, but also because it ended a form of protection from the outside world. Once the barriers came down, all kinds of influences flooded into Tajikistan, along with the material infrastructure through which to 
relate to them, such as video-cassette recorders (VCR) for watching movies, particularly pornography, the subject of this paper.

My discussion on the influence of pornography on marital sexual relations in the republic starts with the story of Sitora and Haydar, and proceeds to a history of sex in the Soviet Union and Central Asia, in order to set the scene for a discussion on the effect of pornography on relationships in Tajikistan today.

\section{Sex in the Soviet Union}

\section{Sex in Soviet Tajikistan}

By the time we met in 1994, Sitora was elderly and living alone but seemed to welcome the chance to discuss her sex life.While reminiscing about her early-married years, she spontaneously brought up her marital relationship.

She told me that on her wedding night she had known nothing about sex despite having lived in the country and seen animals performing such acts. Before proceeding to deflower her, Haydar apologetically explained that it was an obligatory part of the wedding ritual. Sitora said the experience was most painful, and the following day she felt dreadful and could hardly walk. Gradually she got used to sex, although she still did not like it and found it unfortunate that Haydar wanted it so often. As time went on her opinion did not change; she only put up with sex because of her love for Haydar and the fact that her mother-in-law had told her that if she did not comply with his demands, he might go to other women.

They had been married some three years when Haydar overheard his Russian workmates discussing how to turn a woman on in bed. One of them was talking about what a man should do for his wife to enjoy sex. He said the woman had to climax first and only then should the man let himself go. Haydar confessed that he had never given any thought to his wife's pleasure. The Russians were amazed that she had allowed such behaviour. Haydar said they had not known a woman could enjoy sex so it had not occurred to his wife that she had been treated unfairly.

That afternoon, Haydar went home and attempted to try out what he had learned. Sitora became furious, accusing him of having a lover and of practising on his wife the tricks he had learned with his 
mistress. "Don't treat me like your whore!" she shouted. Haydar protested his innocence but Sitora wouldn't believe him. Every night he tried to give her pleasure in bed and every night she refused to allow it. Eventually, he couldn't stand it any longer and told her where he had learned these new actions, but she still didn't believe him.

Sitora was so upset, she went to get help from a Russian friend who explained that men discussed sex amongst themselves and that Russian men were much better informed than Tajiks. Realizing that Haydar had probably been telling the truth, Sitora went home and apologised for misjudging him. Only then did she allow him to show her what he had learned; once they got the hang of it, she thought it was great! After that, they never again had sex without him making sure that she was enjoying it as well and they began to have a wonderful time in bed, greatly improving their relationship'. This was a beautiful memory Sitora had of her marriage and one she had never before been able to share. She could not discuss such things even with her sisters or close women friends.

This may seem strange for anyone who has spent time in other Muslim countries where it is possible to speak relatively openly about these issues, at least with friends and acquaintances of the same sex. However, Sitora and Haydar lived in the confining setting of the former Soviet Union, a place with its own specific approach to sex.

\section{A sexual history of the Soviet Union}

In the early days after the October Revolution (1917), there was considerable sexual freedom in Russia. Among the first laws the Bolsheviks passed were ones making marriage a civil contract rather than a religious sacrament, thus facilitating the legalisation of divorce; abortions also became easier to obtain. Even beyond this, a movement began to condemn the sexual restrictions of the previous bourgeois lifestyle (Carleton 2005, 3). For instance, Alexandra Kollontai, the most powerful woman among the Bolshevik leaders, claimed that under socialism sex would be as simple as drinking a glass of water and this opened the doors for all kinds of extra-marital relationships (Kon 1995, 5 Iff).

The supposed aim of these Soviet policies was to allow women more say in their sexual relationships, but because no attempt was

I A longer version of this story can be found in Harris (2004). 
made to equalise gendered power relations, men very much retained the upper hand. As a result of the laxness of social as well as political control over sexuality, men found themselves in a position to impose themselves on women even more than previously. Since resources were now supposedly held in common, in some circles this was taken to include women, conceptualised as belonging to men rather than as partners with them. In some cities, women were declared public goods to be shared among all male inhabitants (Shtern 1979, 24). This led to the development of a concept of free sex as essential to the socialist movement, which in turn allowed men to justify forcing women to participate in all kinds of sex acts. A refusal could result in their being labelled bourgeois anti-socialist reactionaries, a term with significant negative consequences. It was particularly difficult for younger women such as students to resist pressures to give in to male demands; many had abortions or ended up with unwanted babies while others, abandoned upon pregnancy, committed suicide (Geiges and Suvorova 1989; Hohmann 1990; Kon 1995).

These new sexual practices raised government concerns for providing reliable means of birth control. As a result, researchers in the Soviet Union started to develop contraceptive technologies at a time when in North America it was a criminal offence even to advocate their use (Coliver 1995; Kon 1995, 178).

From the mid 1920s, however, after Stalin became Secretary General, a more conservative tack was taken on sex. Aaron Zalkind published books and articles for the use of the proletariat on the "sexual question", stating among other things that the sex act should take no longer than two minutes in order not to distract people's attention from building socialism, a statement repeated for years afterwards (Kon 1995, 57ff; Shtern 1979, 134). In the mid 1930s, with Stalin's persecutions in full swing, laws pertaining to marriage were considerably tightened. Divorce was made difficult, abortion outlawed, and all mention of birth control suppressed. From then until perestroika in the mid 1980s, the public discussion of sex was strongly discouraged.Almost the only writings about sex could be found in samizdat - illegal, home-produced publications circulated under the counter (Kon 1995). The only person I ever met who had actually read any of these was from Novysibirsk, the famous university town, where during his student days in the late 1960s and early 1970s, 
samizdat sex manuals had been available, consisting mainly of Western book translations.

Soviet parents were discouraged from giving their children information about sex and even the mention of it to a student could lead to a teacher's dismissal. A few foreign doctors working in the USSR published accounts of their experiences there. They speak of a very significant level of sexual problems resulting from almost total ignorance. Among issues they addressed were a lack of sexual satisfaction to the point where the majority of Russian women were said never to have experienced an orgasm, considerable brutality around the sex act, and extremely high abortion rates, with a lifetime rate of over twenty-five abortions per woman not uncommon (Grey 1991; Kon 1995; Shtern 1979, 139).

Even in the late 1980s, it was official policy of the Ministry of Health in Moscow that contraceptives were far more dangerous than abortions, and that non-medical professionals (i.e. women) were not to be trusted with them ${ }^{2}$. At the same time, stories abounded on extraordinary sexual practices, particularly in larger towns. For instance, it was said that people were having sex with total strangers in public places, including while riding the metro and buses in Moscow. The large numbers of multiple partners among some social groups was evidenced by correspondingly high rates of STDs, and sexual harassment was common (Kon 1995). I myself witnessed this last aspect both within the Academy of Science buildings in Moscow and on the metro. In addition, I was told that Party officials frequently forced young women into sexual relations; it was also said that most women in high positions in the Communist Party had slept their way there. However, this last allegation may well stem from a sexist underestimation of women's ability to attain promotion through their own efforts.

\section{A sexual history of Central Asia ${ }^{3}$}

While such reports were common in both Russia and Tajikistan, lifestyles differed significantly between the two republics. At the time

2 According to a letter from the chief gynaecologist of the USSR addressed to the chief gynaecologists of the union republics, shown to me by one of its recipients.

3 Where not otherwise attributed, materials in this section are taken from Harris (2004; 2006). 
of the October Revolution, in the sedentary plains regions of what are now Uzbekistan and Tajikistan, girls and women lived largely in seclusion. They could only leave their homes accompanied by a family member and wearing a long cloak over a thick horsehair veil, without even eye holes ${ }^{4}$.

At that time, the region was just coming out of a state of extreme isolation. Once thriving from the traffic of the Silk Road, between around 1500 and 1830 , the region had since been largely cut off from the outside world. The situation changed considerably in the late $19^{\text {th }}$ century after the region's conquest by the Tsarist Empire, which opened the door to travellers from Europe and the United States as well as to large numbers of Russians who had accompanied the army or were working on the railroads.

This openness to the outside world ended with the Revolution. After 1917, Central Asia was once more largely cut off from contact beyond its southern borders. In the mid 1920s, the region was divided into republics; the Republic of Tajikistan in its present form came into being in 1929.

Although males and females were not allowed to mix, in pre-revolutionary Central Asia some form of sex education seems to have been provided, for males at least. A Russian officer stationed in the region in the early $20^{\text {th }}$ century remarked that "The problem of sex is thoroughly explained to boys only eight years old, who are also taught the rules of married life, warned of possible diseases and instructed in preventive and curative measures in explanations as detailed as any to be found in specialized and scientific works on the subject in the West" (Pahlen 1964, 42). I have no idea whether this was also provided to girls, or if the information given to males included anything about female sexuality or women's sexual pleasure.

The sexual revolution that took place in Russia never manifested itself in Central Asia, which only came under full Bolshevik control in the mid 1920s. While the Russian rulers tried hard to persuade the Central Asians to modify their gender identities and bring them closer to those of the Slavs, largely by forcing them to abandon veiling, seclusion and other related customs, they did not succeed in significantly

4 Drawings of women wearing such cloaks and veils (faranja and chachvan) can be found in Harris $(2006,25)$. 
moderating the underlying gender norms. One way these were manifested was in strict control over female mobility, especially of unmarried girls, something that continues to this day.

The suppression of all talk on sexual issues was extended to the Soviet Union as a whole and in Tajikistan at least was accompanied by a fear of even mentioning sex, especially in front of girls, in case this would encourage experimentation. This was largely because the worst that could happen to a man was for his daughter to be unable to demonstrate her virginity on her wedding night, a form of shame so great that in earlier times men could only regain their place in their community through their daughter's death and, in later times, by clear proof of her disgrace through her repudiation and removal from effective family membership.

In such a climate, it is not surprising that parents became completely paranoid about their daughters. The messages they gave them about what would happen should their hymen somehow become ruptured before their wedding night so frightened those with whom I have discussed the issue that they fetishised what they had between their legs to the point of freezing all feeling in that area, for most. That thin membrane became the most important part of their bodies since it was the font of their fathers' and brothers' honour (and by extension that of the entire family). Irrespective of cost, it had to be preserved until the wedding night. As a result, fear of tearing the hymen dominated mothers' attitudes towards daughters from birth; girls were restrained from the slightest movement that might possibly damage the hymen, such as participating in sports, jumping, cycling, and so on. It is hardly surprising then that brides were rarely ready to explore their sexuality. Most women with whom I discussed the subject said that all they knew in advance about the marriage bed was that the experience would be painful and that they would bleed. Some had not even heard of sex and related the bleeding to menstruation.

Thus, it was not uncommon for contemporary Tajik women's experience of their wedding night to be even worse than that of Sitora, with a consequent loathing of anything to do with sex.Among the majority of those with whom I discussed the matter, those who said to have later experienced arousal claimed that this only happened after years of marriage, usually upon reaching their thirties. How much this delay was a function of earlier repression and how much a function of their hus- 
bands' lack of attention to their sexual needs, I do not know but both no doubt played a role. Few men seemed to make any particular attempt to arouse or satisfy their wives. This was true even for some who claimed to want their wives to respond sexually (Harris 2005b).

\section{Sex and gender in post-Soviet Tajikistan}

When I first arrived in Tajikistan in 1994, sex was still a taboo subject. I never heard of anyone being informed about it except immediately before marriage but even this was rare. During the late 1990s, I worked with many hundreds of teenagers in the villages of southern Tajikistan and they all claimed never to have received any information on sex from an adult. In fact, most of the adults I knew barely understood anything about sex themselves. Parents would tell me they couldn't explain anything to their children because they had no information to give them.

While a refusal to provide sex education is understandable in regard to daughters, owing to fears of their possible loss of virginity, one would expect it to be different for sons, but this does not appear to be the case. One man told me the only mention of sex he received from an adult was when his grandmother said to him on his wedding night "Go in there and show you are a man". He said that luckily he was experienced so he knew what to do but when men were not, or if they had problems functioning, no help was at hand. Teenage boys we worked with in a number of villages told us their uncles (in Tajikistan it is uncles and aunts rather than parents who traditionally advise young people about sex) had advised them deliberately to hurt their brides on their wedding night in order to ensure that they would be frightened by them and would thus always obey them, but supplied no further details. A young man who had not been able to consummate his marriage after several months consulted one of our NGO staff. He knew he was supposed to do something, but did not know what; nor did his wife. He had been too embarrassed to ask a family member but felt that our staff members were so approachable that he felt emboldened to speak. In other words, most boys are expected to know what to do with little if any information or help.

While girls must bleed on their wedding night or face disgrace or worse, boys must be capable of penetrating their brides in order to 
make them bleed. One who cannot do so has equally failed in his obligation towards his parents, although this is rarely talked about since it is even more shameful than a girl losing her virginity. In some families a sheet is still placed underneath the bride for her to bleed on, but very commonly it is the groom who blows the whistle if his bride does not bleed. If he does not even manage to penetrate her, he obviously won't know her status, so he may just keep quiet like the young man who consulted our staff member. Conversely, he may try to find a way to put the blame for his impotence on his bride.

One young man who had participated in our NGO's sex education sessions which among other things taught men to respect their brides and give them pleasure, told us after his wedding that his bride had demanded he just get on and do what he had to immediately. She did not seem to welcome the chance to build some kind of emotional relationship first because she had been told that real men just went ahead with their business and she was determined not to allow her husband to fall short of this ideal. When another young man had serious problems with premature ejaculation, his wife saw him as having failed in his performance of masculinity and therefore despised him.

Thus, women may also be rigid in their expectations, even when this would seem to be to their disadvantage. I have met quite a number of Tajik women who, like these two, find it more important for their husband to be admired for his manliness than to have a better relationship with a softer, gentler man who may cause them to be mocked by friends and relatives for his failure to conform. The fact that in these particular cases the events were taking place within the privacy of the marital bed did not provide sufficient excuse for the inappropriate performance of gender, according to these women (Harris 2004).

\section{Sex and knowledge}

Thus, the pre-revolutionary discussion of sexual issues seemed largely to have vanished during Soviet times. In the course of our NGO work, we came across instances of men with so little idea of female anatomy that, not knowing where the vagina was located, they had attempted rather violently to make extra holes in their brides, who had subsequently to be rushed to the hospital pouring with blood. 
The need for information and support on such issues was clearly so great that I ended up training a group of medical professionals to provide sexological counselling for both men and women. We were able to work with women in the Women's Centre we established in Qurghonteppa town in 2000, with funding from the Swiss Agency for Development and Cooperation. However, no donor displayed the slightest interest in funding a centre to support men's needs. This seemed short-sighted since men's problems inevitably impact women but it did not seem to fit the development ethos of the time.

\section{Pornography rears its head}

Glasnost marked the start of a new sexual revolution in Russia. The pressures on enterprises to be financially viable acted as a stimulus for both the publishing and video industry to produce pornography. For the first time since the 1920s, it was permitted to speak openly about sex. After the fall of the Soviet Union, this intensified; many Western pornographic movies were dubbed into Russian and by the mid 1990s, had become easily available (Goldschmidt 1999).

Our NGO worked in the Qurghonteppa region of Khatlon province, mainly with the Gharmis, a religiously conservative group that had supported the Islamic opposition during the civil war of 199297. Tajikistan had been the poorest of the Soviet republics and its economy had been hard hit by the break-up of the union. The civil war was the final blow to employment prospects for the majority, especially in Qurghonteppa, where it had been fought most fiercely. By the late 1990s, large numbers of adult men were working as labour migrants in the Russian Federation. Upon their return, they brought with them new commodities, at that time unknown in Tajikistan. It was in that manner that the first video-cassette recorders came to Qurghonteppa, almost inevitably accompanied by pornographic movies.

Their religious beliefs did not seem to stop Gharmi men from flocking to watch these movies. Those who had never set foot outside Tajikistan seemed especially bowled over by them and eager to try out the new practices shown. In the early days when only one or two men had VCRs, they would invite all their friends round to watch. I remember in one village the shocked tones in which I was informed by a woman that one such viewing had occurred the previous evening. 
Apparently that particular movie had put an emphasis on anal sex because later that night many viewers had attempted this with their wives. The next morning there was almost a riot as young wife after young wife told her mother-in-law she would leave her husband if he ever again tried to force on her such unnatural and repulsive acts.

Another movie showed women on top. After its airing, one of my friends told me the men in her village had become lazy. They wanted their wives to do all the work. The women didn't see why they should. It was their husbands' job to perform sex.

Besides desires to experiment with unfamiliar positions, pornography gave men other kinds of new expectations. One of these was the issue of female pleasure. Nothing in the movies (at least in those I have seen) showed a realistic picture of how to pleasure women. Indeed, the clitoris was largely presented as a male turn-on rather than a source of female delight. True, the actresses writhed and moaned, but in such a way that suggested this was largely for male titillation rather than their own pleasure. The least experienced of the Gharmi men saw it differently. They wished their wives would behave in bed like the porno actresses.

Pornography had not existed in the Soviet Union, at least not openly, and before the late 1980s hardly anyone had even seen a pornographic magazine. To many men, these movies simply reflected the lives of ordinary people in other countries. Indeed, I have seen this elsewhere. When I was in Indonesia in the mid 1990s, people seemed to think that "B" movies from the United States represented "normal behaviour" and that in the streets of the USA, women in various stages of undress would regularly make themselves available to any man who so desired.

The men in our villages seemed to have much the same idea. Many of them did not seem to realise that the videos were staged rather than representations of real life. Thus, they felt cheated when their wives behaved so differently from the women in the movies. At the same time they knew underneath it all that this was not appropriate behaviour for a Tajik wife. In other words, the men were confused by their contradictory desires. They were torn between a longing to participate in the kinds of scenes they were viewing in the movies and the disgrace of having a wife who might react in the same way as the women in the movies. 


\section{The female body}

Another issue that raised concerns among the men was the images of the female body they saw in the movies. They were amazed by the differences between the bodily presentations of these women and those with whom they shared their beds.

Since this was a rural area, their wives worked not only in the home but also in the fields and with livestock. At night, they were often smelly and too tired even to wash, especially when, as was often the case, this first entailed fetching water and the added effort of finding clean clothes to change into. Moreover, they often lacked the money even to buy soap with which to wash properly.

Many women's bodies were misshapen from multiple pregnancies, poor diet, and hard labour. Furthermore, the local traditional dress is intentionally aimed at loosely covering all body parts precisely to prevent male titillation. Some of the younger men went so far as to bring back sexy garments from Russia and ask their wives to wear them in the privacy of their bedrooms to try to get them to look more like the movie actresses. However, the women often could not face dressing up in them. When the men complained, the women simply claimed exhaustion.

Several men's groups raised this issue in the NGO's educational sessions. In order to have them think through some of the implications, NGO staff would ask them to carry out the "24-hour activity" exercise dear to development practitioners where men compare their workloads to that of their women. This often resulted in the former deciding to take on some of their wives' tasks, as far as this could be done without contravening the parameters of appropriate masculinity, in the hope that this would grant them greater sexual access.

While this could reduce their wives' exhaustion levels, it could not change their shapes. The men complained so much about this that some of the women came to me in despair asking for help to make their bodies more beautiful. Among other things, they asked to be trained in gymnastics. However, these approaches did not fit with their lifestyles. Their bulky clothes, lack of support bras, and poor footwear made it difficult for them to do most physical exercises. They also found it difficult to find the time or the privacy to exercise and very soon gave up. 


\section{Male pleasure}

Some women also wanted to learn how to please their husbands sexually. Those whose husbands had second wives in Russia in particular told us that the men had accused them of being boring and they wanted to know how to change. Could we please help them do whatever necessary to keep their husbands happy, especially in bed?

This put us in a quandary. What exactly did these women want of us? The idea that we were being expected to teach our Gharmi women to behave like the women in the porno movies was mind-boggling! How much did they understand of what it was their husbands were demanding of them? Were we to have sessions where we showed the movies and helped the women emulate the actresses? Obviously, this was unlikely to be what the women really wanted. They would very likely have been disgusted by the pornography, and no doubt by us for showing it to them. The very idea of encouraging the women to sacrifice themselves still further to please their men and in this particular way was a very poor fit with our aims of helping the women gain greater self-esteem.

Another and obviously preferable option was to help the women enjoy sex by supporting them to explore their feelings towards their husbands and in their erogenous zones. However, for most of these women who seemed never to have experienced sexual arousal let alone fulfilment, this was a tall order. Moreover, it would require lengthy and patient cooperation from their husbands, few of whom would be likely to go along with this.

Elsewhere I have written about Zebo, who came to me for help when her husband was on the point of divorcing her because he was so fed up with her lack of response during sex. It took months to get her to the point of experiencing arousal and still longer for her to become capable of receiving sexual satisfaction through intercourse. It was worth it for her since in the end this not only saved her marriage but also brought her emotionally close to her husband for the first time (Harris 2005b).

The majority of our rural men, however, would be unlikely to cooperate in such a venture. While they would complain to our male staff that they did not enjoy their wives "laying there like logs" in bed, they were none too sure they really did want them to enjoy sex. It was unclear whether they really wished their wives would act like the 
women in the movies or whether they just would have liked to be in bed with someone different and took it out on their wives that they were stuck in the village with them. Whatever the case, they seemed to pay little attention to their wives' feelings.

Our staff members tried to explain that it was unrealistic and unfair to expect real women to behave like film actresses or indeed like the prostitutes many men claimed to have visited in Russia. Those men who had long-term partners in Russia insisted they enjoyed sex much more with them than with their Tajik wives. When asked whether they did anything different in bed, the men reluctantly admitted that the Russian women had showed them how to please them and that they had learned to enjoy sex in that way. Our staff then suggested they might be able to solve the problem by trying to please their Tajik wives in the same way. However, most of these men categorically refused.

They insisted that if their wives started to enjoy sex they would probably want it all the time. However, the men were forced to spend long periods away from home. It was only the fact that their wives did not like sex that allowed the men to believe they were most probably faithful during their long absences. This allowed them to feel like real men in proper control. The slightest suspicion within the village that their wives were cuckolding them would lead to disaster.

It was different in Russia, the men explained. There, masculinity was not defined in the same way. Nobody would laugh at them if their partners were seen talking with other men, but should that happen in Tajikistan, it would destroy them. Even their peers would regard such incidents completely differently depending on where they occurred. Moreover, in Russia it was the women who had the upper hand, since they had more money and in many cases the men were living in the women's homes. For another thing, everyone knew that Russians were far more lax than Tajiks, and that it was quite common for Russian men not to control their wives. It was therefore acceptable for Tajik men to emulate them in regards to Russian women but only in Russia, not back home in Tajikistan. In other words, these men had learned to perform two quite different varieties of masculinity, both strongly tied to sexuality, but they were careful to keep each to its appropriate setting.

This made it impossible to resolve the situation to anyone's satisfaction. It was quite clear that as long as the men put their masculinity 
before all other considerations including both their own pleasure and their marital relationships, there could be no happy solution. The men therefore continued to feel bored and the women to feel inferior because their husbands seemed to want it both ways - they wanted their wives to behave like well brought up Gharmi women and like porno actresses at the same time, to satisfy them sexually while supporting their performance of masculinity in and out of bed.

Some of the worst situations occurred at the time of marriage. Men who had never had sex before or who had never had it with a "good" Tajik woman would have completely unrealistic expectations of their brides, which the women could neither understand nor cope with. Women with no knowledge of sex were being expected to act like porno actresses and to be turned on by whatever their husbands did to them, irrespective of how unpleasant or painful this might be. This sometimes produced very strong reactions. Some women ran away on their wedding nights. Others would never willingly allow their husbands to touch them again. Some men even sent their brides back to their parents in disgrace for repeatedly refusing sex.

I should state here that most of these couples had never set eyes on one another before their wedding day. Although Sitora and Haydar managed to marry for love many decades ago, this remains unusual among Gharmis, for whom it is still normal for two complete strangers to have to go to bed together without having the chance even to get acquainted. They may dislike each other at sight, be in love with someone else, or be totally unprepared for marriage and, even if attracted to one another, will have had no opportunity to build a rapport to help them through the difficult moments. The bride may know nothing about sex and/or be terrified about what is going to happen. Traditionally she is supposed to be totally passive and the groom is supposed to be in charge. A woman who reacts too sexually would be considered experienced and penalised for it even if she had demonstrated her virginity by bleeding.

Thus there are acute contradictions between women's expected behaviour before marriage, their reactions on their wedding night and the subsequent pressures on them to behave sexually in bed. These are compounded by the fact that their husbands either know nothing about female sexual arousal or do not wish to arouse their wives. They just want to have a good time in bed without considering their 
feelings. This virtually amounts to men treating their wives like prostitutes. Women's desires, their experiences of pleasure or of pain become irrelevant. While clearly not every man behaves or thinks like this, all too many seem to do so, judging by the number of horror stories told to the members of our NGO. If the men were heroin addicts, something increasingly common in Tajikistan, the problems were greatly compounded. The appearance of pornography added an extra few layers of male expectations and consequent pressures on wives.

\section{Conclusion}

The insistence of those in the Tajik women's movement that sex was unimportant was exposed as false both by my ethnographic research, for instance, my work on the lives of Sitora and Haydar, and by the Gharmi women and men we met through our NGO work. Indeed, both showed sex to be as central to marital relations in Tajikistan as it is elsewhere, an improvement in the one usually resulting in an equivalent improvement in the other. Perhaps a remnant from the Soviet period, the women's movement member attitude, therefore, seems detrimental to themselves as well as to other women.

The lack of meaningful sex education in Tajikistan, in part resulting from the Soviet heritage, together with the total silence around sex, was compounded by the arrival of pornographic movies, which provided false and misleading information on female sexuality to men with no other means of information and learning. Even those men who had some understanding of female sexuality were generally unwilling to try to satisfy their Tajik wives sexually for fear that this would prove an obstacle to their maintaining appropriate norms of masculinity. In fact, the insistence on conformity to gender norms turned out to be the greatest barrier to sexual and emotional satisfaction for both men and women, with or without the influence of pornography.

\section{References}

Carleton, G. 2005. Sexual revolution in Bolshevik Russia. Pittsburgh, PA: University of Pittsburgh Press.

Coliver, S. 1995. The right to know: human rights and access to reproductive health information. Philadelphia: University of Pennsylvania Press. 
Geiges, A., and T. Suvorova. 1989. Liebe steht nicht auf dem Plan: Sexualität in der Sowjetunion heute. Frankfurt am Main:Wolfgang Krüger Verlag.

Goldman, W. Z. 1993. Women, the state and revolution: Soviet family policy and social life 1917-1936. Cambridge: Cambridge University Press.

Goldschmidt, P. W. 1999. Pornography in Russia. In Consuming Russia: Popular culture, sex, and society since Gorbachev. (Ed.) A. M. Barker. 318-336. Durham N.C.: Duke University Press.

Gray, F. d. P. 1991. Soviet women walking the tightrope. London:Virago Press.

Harris, C. 2006. Muslim youth: tensions and transitions in Tajikistan. Boulder, CO: Westview Press.

—. 2005b. Tackling sexual distress: two case studies from the Central Asian Republic of Tajikistan. In Rethinking masculinities, violence and AIDS. (Eds) D. Gibson and A. Hardon. 175-200. Amsterdam : Het Spinhuis.

2005a. Desire versus horniness: sexual relations in the collectivist society of Tajikistan. Social Analysis. 49(3): 78-95.

—. 2004. Control and subversion: gender relations in Tajikistan. London and Sterling, VA/Ann Arbor, MI: Pluto Press and Michigan University Press.

Hohmann, J. S. (Ed). 1990. Sexualforschung und -politik in der Sowjetunion seit 1917. Frankfurt/M., Bern, New York, Paris.

Kon, I. 1995. The sexual revolution in Russia, from the age of the Czars to today. New York and London:The Free Press.

Pahlen, Count K.K. 1964. Mission to Turkestan. London: Oxford University Press.

Shtern, M. (with A. Stern) 1979. Sex in the USSR. (Edited and translated from the French by Mark Howson and Cary Ryan). New York:Times Books. 


\title{
Féminités et masculinités en mouvement: échanges économico-sexuels à Bamako
}

\author{
Fenneke Reysoo*1
}

\section{Introduction}

L'un des gains les plus importants de la Conférence internationale sur la population et le développement (CIPD, Le Caire 1994) a été la prise de conscience par la communauté internationale de l'étroite articulation entre la reproduction humaine et les constructions culturelles de la sexualité. Ce changement paradigmatique a contribué à la prolifération de recherches sur les pratiques sexuelles des hommes et des femmes dans des contextes culturels très divers. La CIPD a également été la conférence qui a permis de mettre en avant la perspective de genre sur l'agenda du développement. Le nombre élevé de grossesses précoces, la prévalence des maladies sexuellement transmissibles, y compris le VIH/SIDA, parmi les jeunes filles constituaient le nouveau cadre pour problématiser et comprendre les rapports de force inégaux entre (jeunes) hommes et (jeunes) femmes en matière de sexualité et de santé de la reproduction.

* Anthropologue, Institut de hautes études internationales et du développement, fenneke.reysoo@graduateinstitute.ch

I Je tiens à remercier ici Maïmouna Ndoye et Françoise Grange Omokaro pour leurs commentaires constructifs sur une version antérieure de cet article.

Reysoo, F. 2012. Féminités et masculinités en mouvement: échanges économicosexuels à Bamako. In Chic, chèque, choc. Transactions autour des corps et stratégies amoureuses contemporaines. $7 \mathrm{I}-9 \mathrm{I}$. Actes des colloques genre et développement. Berne: DDC-Commission suisse pour I'UNESCO; Genève: IHEID. 
La recherche que nous avons menée en 2005 à Bamako (Mali) ${ }^{2}$ s'inscrit dans cet effort des organisations internationales (FNUAP, OMS et coopérations bilatérales) pour renforcer le statut des (jeunes) femmes afin de créer un environnement où elles peuvent vivre une sexualité sans risques, sans coercition ni violences. Notre collaboration avec le programme de la santé de la reproduction de l'OMS s'est inscrite dès le départ dans la perspective de «genre et droits en santé de la reproduction». Nous étions théoriquement préparées à analyser la position subordonnée des (jeunes) femmes dans les rapports sexuels afin de formuler des recommandations pour leur empowerment. Quelle ne fut pas alors notre surprise en arrivant sur le terrain à Bamako d'être confrontées à un "phénomène» social - qui ne cadrait pas avec ces représentations dominantes de jeunes femmes subordonnées et victimes. Le terrain venait littéralement à notre rencontre dans toute sa splendeur. Dans mon carnet de note, lors d'un voyage préparatoire, j’avais noté:

Partout à Bamako, j'observe des bars chinois ou des Eden Parcs, euphémismes pour désigner des lieux de passe. Un collègue me dit que c'est un "phénomène» dilué, mais omniprésent, un autre me confirme que ce sont des lieux de pratiques douteuses. Une autre connaissance ajoute: « Les familles n'ont plus d'emprise sur le comportement des filles». La sexualité «commerciale» avant le mariage semble devenue une nécessité. C'est normal, me dit-on, les filles doivent ramener les condiments à la maison. (Reysoo, 2004, journal de terrain)

Plusieurs éléments contenus dans cette petite narration se sont avérés importants dans notre recherche qui a consisté à comprendre ce «phénomène» dans lequel les jeunes femmes semblent être des protagonistes proactives et très visibles. D'un côté, ce "phénomène» se réfère à un discours sur une sexualité débridée de jeunes femmes non mariées. Ces pratiques semblent être omniprésentes et moralement

2 Les données présentées sont issues d'un terrain d'enquête conduit de juillet à octobre 2005, en collaboration avec Françoise Grange Omokaro, dans le cadre d'un projet de recherche sur Genre et Droits en Santé de la Reproduction mené en partenariat avec l'Organisation mondiale de la santé (OMS) et financé par le Réseau universitaire international de Genève (RUIG). 
décriées. De l'autre côté, cette sexualité monnayée est liée à une situation de pauvreté et à une division sexuelle du travail au sein des ménages. En effet, les parents ne pourvoient plus seuls aux besoins des ménages et les filles ont le devoir de ramener des condiments à la maison. Par conséquent, la pauvreté induirait et justifierait ces pratiques. En même temps, le rejet moral de cette sexualité à la fois monnayée et prénuptiale est mis en lien avec la perte de contrôle des parents sur leurs filles. Intriguées par ces images de la réalité sociale en rupture avec la morale et les normes d'une époque antérieure, nous avons décidé d'approfondir ce "phénomène» et les transformations des identités féminines et masculines qui les sous-tendent.

\section{Echanges économico-sexuels : exploration conceptuelle}

FG: Les proportions que vous annoncez sont énormes si vous dites que sur 100 filles il $y$ en a 40 ou 50 qui se prostituent.

AS: Ce n'est pas énorme. D'ailleurs la proportion, je vais vous poser une question à laquelle on n'a pas vraiment répondu à mon avis. Vous savez la prostitution des adolescentes est beaucoup plus élevée. On pourrait même inclure les jeunes entre 15 et 17 ans. Elles n'ont pas encore l'âge majeur, elles sont mineures. À cet âge-là, Bamako est déjà investi de ces transactions. (AS, homme de 40 ans)

Le "phénomène», dont on nous a parlé et qui est largement décrit dans la presse locale, est généralement désigné par le terme de prostitution. Néanmoins, les jeunes filles qui s'engagent dans ces rapports sexuels avec échange d'argent ou de cadeaux ne se définissent pas comme prostituées elles-mêmes. L'écart entre les représentations et le vécu nous a poussées à réfléchir sur le champ sémantique qu'englobe le terme de prostitution à Bamako. C'est ainsi que l'œuvre de Paola Tabet et son concept d'échange économico-sexuel nous a semblé utile. Le terme de transactions économico-sexuelles qu'elle introduit se définit comme: "relations between men and women involving some kind of compensation given by the man for the sexual services of a woman » (Paola Tabet, dans cet ouvrage). Défini ainsi, ce concept nous a ouvert de nouvelles perspectives pour penser le «phénomène». Tabet propose de parler d'un continuum en tenant compte du statut des 
partenaires impliqués (notamment selon leur cycle de vie, mariés ou non), de la durée de la rencontre (occasionnelle ou stable), des transactions matérielles (argent, cadeaux, etc.) ou symboliques (prestige, statut social). À un extrême du continuum, se situe le rapport sexuel matrimonial et, à l'autre extrême, le rapport sexuel commercial contractuel. Selon Tabet, le concept de prostitution est inapproprié, car il divise les femmes de façon binaire entre celles qui sont décentes et celles dont le comportement est indécent. L'assignation du terme de prostituée à certaines femmes les stigmatise et les exclut socialement. L'assignation du stigmate de prostituée se trouve de ce fait au cœur des enjeux de pouvoir autour de l'identité féminine, d'autant plus qu'il n'y a pas de définition univoque de la prostitution ou de la prostituée. En effet, le même acte sexuel peut être considéré comme normal dans un contexte et comme relevant de la prostitution dans un autre (Tabet 200 I).

Se basant sur un vaste corpus de monographies ethnographiques, Tabet découvre une constante: lors d'un acte sexuel entre un homme et une femme, il y a toujours une forme de compensation offerte par l'homme à la femme. Même dans une société aussi égalitaire que celle des lles Trobriand étudiée par Bronislaw Malinowski (1922) où les mœurs sexuelles sont très libres et où les filles, tout autant que les garçons, peuvent initier un rapport sexuel, les garçons offrent quelque chose à la fille. Malinowski décrit ce don comme relevant de la tradition et ne questionne pas l'uni-directionnalité de cette compensation. Pour Tabet, le fait qu'il y ait cette compensation transforme l'acte sexuel en un fait social. Selon elle, il n'existe nulle part une relation sexuelle dans un système clos où la sexualité est échangée contre la sexualité. Partout, la sexualité de la femme serait rétribuée et de ce fait transformée en service rendu.

Pour mieux comprendre cette logique, elle fait un détour par la théorie sur le don élaborée par Marcel Mauss (1923). Mauss propose de considérer le don comme une logique de renforcement du tissu social. Au moment où quelqu'un offre quelque chose à quelqu'un d'autre, celui-ci ne se trouve pas seulement dans la position de devoir recevoir, mais également dans celle de devoir rendre. C'est le devoir de réciprocité qui tisse le lien social. La compensation payée aux femmes par les hommes assure ainsi à ces derniers l'accès à la descendance. Considéré ainsi, le contre-don des femmes est la progéniture et non pas leur sexualité. 
La capacité des femmes à donner la vie a certes structuré les rapports sociaux et notamment ce que Gayle Rubin (1975) a appelé le système sexe-genre en se référant aux théories de l'échange de femmes élaborées par Claude Lévi-Strauss (1949). Partant du tabou universel de l'inceste, Lévi-Strauss avance que l'exogamie est le principe premier de toute organisation sociale. La démonstration faite par Lévi-Strauss est éminemment androcentrée: si l'homme ne peut se marier ni avec sa mère, ni avec sa sœur, il est bien obligé de prendre épouse en dehors de son lignage. II échange alors sa sœur contre la sœur d'un homme d'un autre lignage. Dans la théorie de Lévi-Strauss, les femmes sont ainsi les objets échangés et les hommes les protagonistes actifs de l'échange. L'accès aux femmes exogènes garantit ainsi la reproduction du groupe ${ }^{3}$.

En passant en revue les théories de Malinowski, Mauss et LéviStrauss, Tabet s'étonne qu'aucun des trois n'ait problématisé la hiérarchisation de genre inhérente aux logiques observées. Le fait que l'homme paie pour le service sexuel de la femme était considéré comme une évidence; le transfert en sens inverse n'ayant pas été observé. La conclusion qu'en tire Tabet est que la sexualité des femmes est partout considérée comme un service pour lequel un homme paie, ou du moins pour lequel il engage une compensation sous forme de don (d'argent, de promotion sociale, de prestige) (Tabet 200I).

Lorsque nous avons entamé notre travail de terrain à Bamako, les échanges économico-sexuels étaient au centre des informations que nous recueillions au sujet des pratiques sexuelles des jeunes femmes. Pourtant, au lieu d'être considérées comme des pratiques «évidentes», elles étaient entourées de récriminations morales. II nous fallait donc approfondir ce "phénomène» afin d'analyser ce qu'il pouvait nous apporter dans la compréhension des rapports de genre parmi la jeunesse à Bamako et les problèmes liés à la santé reproductive en ce début de $\left.X X\right|^{\text {e }}$ siècle. Dans cet article, je présenterai tout d'abord quelques caractéristiques socio-économiques et culturelles de la vie des jeunes à Bamako à l'heure actuelle. Dans un deuxième temps, je relierai les pratiques observées au concept de transactions économico-

3 Je n'entre pas ici dans le débat mené par de nombreuses chercheures féministes sur le biais androcentré et la non-problématisation de l'absence d'agency des femmes. 
sexuelles en décrivant la nature de ces échanges et leur lien avec l'émergence d'identités masculines et féminines d'une jeunesse mondialisée (voir aussi Grange Omokaro 2009).

\section{Le Mali et sa capitale Bamako}

Pour comprendre le "phénomène» des échanges économico-sexuels, nous commençons par présenter quelques éléments du contexte socio-économique et culturel dans lequel vivent les jeunes qui ont participé à notre étude. En 2007, le Mali est un pays démocratique multipartite dont les recettes publiques consistent pour $70 \%$ en aide au développement. Le revenu net par habitant est parmi les plus bas au monde (380 US dollars en 2005 selon la banque de données du World Development Indicators de la Banque mondiale). Le gouvernement est confronté à d'immenses enjeux de développement; les jeunes notamment se trouvent face aux défis d'une nation pauvre qui fait partie d'un système mondial interconnecté par le commerce, l'information et la communication.

La perception des conditions de vie des jeunes à travers le regard de différents interlocuteurs, âgés et jeunes, permet de saisir les transformations en cours et leur appréciation. C'est tout d'abord l'historien Bakary Kamian (80 ans) qui nous a donné un aperçu historique du Mali. Selon lui ${ }^{4}$, depuis l'indépendance en 1960, le pays a connu une urbanisation soutenue. La population nationale, extrêmement jeune, a quadruplé depuis lors ce qui fait que huit Maliens sur dix sont nés après l'indépendance. Les jeunes de moins de vingt ans représentent plus de la moitié de la population actuelle (donc environ sept millions de personnes). Dans les années 1950-1960, les villes étaient à majorité masculine. Le départ des jeunes de leurs villages faisait partie de leur initiation d'homme. On leur disait, «maintenant tu es un homme, va t'en très loin, reviens riche ou va mourir très loin » (entretien avec Kamian).

Avec le passage du parti unique (Modibo Keïta) à un système multi-partite (en 1991), la jeunesse est devenue un enjeu politique important (voir aussi Biaya 200 I pour le Sénégal). Comparé au passé, la jeunesse a changé. «Nous avons souhaité la libération politique du régime colonial, nous aspirions à pouvoir faire ce que nous voulions, à

4 Nous présentons l'essentiel de son esquisse historique en le paraphrasant. 
donner l'éducation que nous voulions à nos enfants» (entretien avec Kamian). Malgré une scolarisation massive, une augmentation de l'espérance de vie, une amélioration des infrastructures sanitaires, il y a eu une perte des repères culturels traditionnels. En milieu urbain, les structures traditionnelles de surveillance et de solidarité ont rapidement éclaté. Et la société s'est ouverte sur le monde. «L'audiovisuel importé, ou bien qui nous est parachuté, qui nous est surimposé par les airs, par les ondes électromagnétiques, ces télévisions, ces mass médias ont complètement bouleversé nos façons de voir les choses. Ce que nous voyons en Europe, les images de l'Europe, de l'Occident, toutes ces images-là ont transformé complètement les mentalités, les manières d'être, les manières de penser, les manières de se comporter de nos jours» (entretien avec Kamian).

Ces changements matériels et culturels sont intervenus en un laps de temps très court. Les premières élections démocratiques ont eu lieu en I99I, et, avec elles, de nouvelles institutions et lieux d'autorité ont émergé. Un chef de quartier, âgé de plus de 80 ans, esquisse une dégradation du lien social sur un ton nostalgique. «Avec l'avènement de la démocratie en 1991, les gens jouissent de libertés incontrôlées. On assiste à une perte d'emprise des parents sur leurs enfants. C'est, entre autres, la conséquence des activités des associations des droits humains, des droits de l'enfant et des droits des femmes. Tout d'un coup on ne pouvait plus châtier les enfants à l'école ». Notre interlocuteur regrette en fait que l'autorité traditionnelle des chefs de familles, des pères et des maris, s'érode par la mise en place d'un cadre de droits humains et d'égalité. L'érosion de cette autorité traditionnelle s'applique également au corps enseignant, car selon lui : "Les scolarisés recevaient une bonne éducation civique et morale, jusqu'à la réforme scolaire de 1992. Depuis lors, les professeurs n'ont plus le droit de châtier les enfants, les enfants se croient tout permis». Dans sa conception, la démocratisation sape en quelque sorte le respect des traditions ancestrales. II est intéressant de noter que ce chef de quartier âgé perçoit la mondialisation comme porte d'entrée de nouvelles mœurs: "La mondialisation veut tout simplement dire "calquer" l'Occident. Mais la mondialisation est pour ceux qui sont riches. Les Maliens n'arrivent même pas à manger (il faut 500 francs CFA/jour pour faire manger une famille). La prostitution des filles doit être vue dans ce contexte-là. On dit que $60 \%$ des filles se prostituent. La vie au 
Mali est un combat. Les garçons et hommes riches peuvent tout se permettre, aussi se payer des filles tant qu'ils veulent».

La dégradation des mœurs et la démission des parents sont des thèmes récurrents. Une autre interlocutrice (45 ans) nous dit: «Les enfants d'hier écoutaient ce que leur disaient les parents, il y avait moins de problèmes. Traditionnellement, avant de se marier les jeunes (hommes) devaient avoir un emploi ». L'époque actuelle demande d'adhérer au projet de modernité et de mondialisation. «De nos jours, il faut envoyer les enfants à l'école, sinon ils ne trouveront pas de boulot. Mais sous l'emprise de l'école, l'autorité des parents sur les enfants s'érode» nous affirme la dame précitée. Le paradoxe du développement est que de plus en plus de jeunes sont allés à l'école et sont détenteurs de diplômes, mais la disponibilité d'emplois sur le marché du travail ne suit pas les demandes.

Aussi bien l'historien Kamian que ce chef de quartier font le bilan d'un bouleversement sociétal profond. La jeune génération des Maliens, née après l'indépendance, évolue dans un contexte démocratique basé sur des valeurs d'égalité et de liberté. La vieille génération se trouve devant le constat de l'érosion des formes traditionnelles d'autorité et de contrôle social. Par ailleurs, la jeune génération, et surtout les garçons, doivent choisir des voies professionnelles dans un contexte de rareté d'opportunités. Et tandis qu'il leur est difficile de générer des revenus, ils sont exposés aux images venues d'ailleurs qui font miroiter les merveilles d'une société de consommation et de ce fait induisent de nouvelles aspirations. Pour résumer, on peut dire qu'à l'heure actuelle, les hommes et femmes, jeunes et âgés, sont amenés à réaliser leurs projets de vie dans une société complexe, très diversifiée et ouverte sur le monde.

\section{Le «phénomène » de la sexualité prolifique à Bamako.}

Comme nous venons de le voir, il y a un discours dominant à Bamako sur les changements de mœurs et la liberté débridée en ce qui concerne la sexualité des jeunes. Le "phénomène» est appréhendé de diverses manières. Certains interlocuteurs le pensent de façon quantitative: « $60 \%$ des filles se prostituent». D'autres s'expriment sur un registre moral et le rejettent. La récrimination morale concerne avant 
tout le comportement des jeunes femmes: «Elles n'en font qu'à leur tête ». La dégradation morale est, comme nous venons de le voir, également mise sur le compte des parents: «lls n'ont plus d'emprise sur leurs enfants ». Quelques uns, bien minoritaires, émettent un jugement désapprobateur sur les hommes d'un certain âge et riches qui détourneraient les filles de plus en plus jeunes. «C'est de la pédophilie purement et simplement qui ne dit pas son nom. C'est exactement ça. Ça ne dit pas son nom. Un vieux qui marie une fille de 16 ans, c'est de la pédophilie pure et simple» (AS, homme de 40 ans). Exprimées ainsi, les appréciations sont plutôt négatives et il est évident que le "phénomène » en dérange plus d'un.

Cependant, certains interlocuteurs témoignent d'un jugement plus mitigé. Ils justifient ces pratiques, ou pour le moins ils l'expliquent, par la pauvreté. Les jeunes femmes sont poussées à générer des revenus par la vente de leur corps dans un contexte de pauvreté, d'autant plus que la crise économique affecte plus durement les femmes que les hommes.

Regardons de près les différents registres qui sont mobilisés pour apprécier, tolérer ou rejeter le "phénomène» des transactions économico-sexuelles. Un premier registre peut être qualifié de moral et religieux. Par le passé, une sanction surnaturelle frappait les comportements transgressifs: "Avant il était interdit d'avoir des rapports sexuels hors mariage, mais aujourd'hui c'est la liberté. Les gens se livrent à la débauche. Les gens ne disent plus: "Ah si je fais l'amour à quelqu'un d'autre que mon mari, un tel fétiche me tuera". Aujourd'hui, il n'y a plus de menace de fétiche, du divin, on dit que Dieu est trop loin des hommes. Alors les gens s'en foutent» (entretien avec Kamian).

La crainte de la sanction surnaturelle semble avoir fait place à l'appât de l'argent. «Par le passé, les jeunes respectaient tout le monde, ils étaient dignes. Ils n'étaient pas orgueilleux comme aujourd'hui. À l'époque, les jeunes ne pensaient pas trop à l'argent. Les enfants étaient obligés d'obéir à leurs parents. De nos jours, dans les grandes villes, les parents ne contrôlent plus leurs enfants» (entretien avec Kamian). La complexité d'une société dont le modèle sociétal autrefois basé sur l'autorité des aînés devient individualiste et consommateur apparaît dans ces témoignages. À cela s'ajoute la pauvreté: «La pauvreté pousse les enfants à se débrouiller dans la rue, il n'y a plus toujours de quoi manger à la maison. Les garçons à partir de 15 ans 
peuvent aller chercher un travail d'ouvrier. Mais les filles de cet âge-là doivent travailler dans la famille avec leurs mamans. Si tu les pousses à faire de la vente dans la rue, elles vont se prostituer là-bas. La pauvreté fait que les filles n'ont pas assez de moyens, elles veulent quand même être bien habillées. Elles trouvent des copains plus riches qu'elles. Chacun a laissé la religion, ses coutumes quoi» (KC, guérisseur). La pauvreté se conjugue ici non seulement avec le manque d'argent pour assurer l'alimentation d'une famille, mais également avec l'impossibilité de consommer les biens plus luxueux qui permettent d'être à la mode (Reysoo 2009).

Cela nous mène vers un deuxième registre qui permet de comprendre l'émergence du «phénomène». Ce registre est également d'ordre moral, bien que séculier. «La débauche s'est beaucoup répandue. Les jeunes gens, garçons et filles, veulent satisfaire leur instinct sexuel. Le fait qu'il y ait des pilules, le fait qu'il y ait des contraceptifs, qu'il y ait le condom Protector, tout cela est venu alors aggraver parce que l'on se dit: "On peut faire l'amour sans risque, alors on y va". Avant on ne pouvait avoir de rapports sexuels hors mariage, mais aujourd'hui c'est la liberté» (entretien avec Kamian). L'éternel dilemme de savoir si la disponibilité des informations sur la sexualité et la mise à disposition de moyens contraceptifs incitent les jeunes à s'engager dans les rapports sexuels ou s'il s'agit d'un véritable besoin pour protéger les jeunes sexuellement actifs est soulevé ici.

Une guérisseuse dit: "Les centres de santé reproductive poussent les enfants à avoir des rapports sexuels avant le mariage, et pour cette raison je désapprouve cette institution ». Et un autre guérisseur nous dit: "Les jeunes filles font n'importe quoi. Et elles viennent ensuite pour se faire avorter. II y a aussi beaucoup de jeunes filles qui ont des enfants avant le mariage. C'est un phénomène nouveau. À l'époque, si tu faisais ça, tu serais obligée de quitter le village. Mais aujourd'hui, il y a des familles pauvres. Les enfants font des bêtises, parce qu'il leur manque des choses ॥. II témoigne ainsi d'un changement de mœurs et de conditions économiques.

Traditionnellement, la honte et la mise en accusation publique avaient pour fonction de dissuader les gens de transgresser les normes. Mais sous l'effet de la pauvreté, c'est-à-dire par manque d'argent, les perceptions se transforment et les normes semblent se déplacer. Pour réaliser leurs projets de vie, jeunes hommes et jeunes 
femmes ont besoin d'argent. Et cet argent n'est pas accessible lorsque les parents sont trop pauvres et lorsque les emplois sont rares. Comment font les jeunes pour être branchés? Dans ce qui suit, nous analyserons les enjeux identitaires des jeunes garçons et jeunes filles.

\section{La culture des jeunes}

Le fait de vouloir être branché fait partie de la culture des jeunes. À Bamako, aussi, on assiste à l'émergence d'une culture de jeunes et de la célébration d'une étape de vie sans trop de responsabilités. Cette étape de vie coïncide généralement avec la période de formation ou des études. De plus, de nos jours, les jeunes Bamakois n'échappent pas à certaines influences d'une culture de jeunes mondialisée. Ils s'expriment par des modes musicales et vestimentaires et des quêtes identitaires. L'univers hip-hop et rap malien et ses symboles d'appartenance nous en donnent un bel exemple. Cet univers nous est dévoilé par le présentateur d'un programme de hip-hop à la télévision malienne ${ }^{5}$. Selon lui, le hip-hop est une culture, constituée de chant (rap), de danse (break dance), de graffitis. Les hip-hop ont également une culture vestimentaire: des pantalons larges en bas du nombril, de grosses chemises, des casquettes mises à l'envers. Ce style se caractérise par son aspect «bling bling». Dans le jargon rap cela veut dire tout ce qui brille, les bijoux, les diamants, les bracelets, les montres, les boucles d'oreille. Ce mode vestimentaire ne cadre pas toujours avec la culture malienne: la boucle d'oreille pour les garçons par exemple.

Les hip-hop ont également un langage particulier: «kiffer» veut dire aimer. La culture hip-hop pour les garçons c'est aussi une façon d'attirer les filles, cela permet de faire la différence entre «mec branché » et «mec à côté de la plaque». Pour participer à la culture hiphop, il faut pouvoir se donner les moyens. Le prix d'un pantalon peut s'élever jusqu'à 30000 ou 35000 francs CFA et le pouvoir d'achat du Malien est faible. D'après Braddox, pour un père (sic) ce n'est pas évident de donner 30000 francs CFA à son fils pour un seul jeans: «Les garçons font l'impossible pour avoir ça. Pour les fils à papa c'est vraiment aisé, mais pour les autres... Certains font du business pour

5 Les passages suivants sont un résumé de l'entretien avec ce présentateur, qui s'appelle Braddox. 
pouvoir y accéder. II y en a qui travaillent en dehors des heures d'études pour s'offrir ces choses. Pour être branché, il te faut des souliers Adidas ou Reebok, sinon tu es vraiment out.» À Bamako, un seul magasin vend des vêtements hip-hop originaux, mais les points de vente de contrefaçon sont nombreux. La distinction est de rigueur: «Les jeunes qui portent du toc ou de la friperie sont repérés tout de suite».

Pour pouvoir obtenir ces vêtements et gadgets à la mode, les jeunes hommes s'y prennent différemment des jeunes femmes. Braddox nous explique: «Tandis que les mecs font leur petit business, la stratégie des filles, c'est les hommes justement. Une fille, quand elle sort avec son petit ami, c'est ce dernier qui est censé lui offrir tout ce qu'elle veut. Donc les filles qui n'ont pas assez de moyens, et dont les parents ne sont pas aisés, préfèrent se rabattre sur leur petit ami». Les jeunes femmes mettent ainsi à leur profit la logique inhérente des transactions économico-sexuelles décrite par Tabet. Toutefois, le profit qu'elles peuvent en tirer se conjugue de différentes manières. En effet, Braddox esquisse le tableau suivant:

Mais, en général, les filles ne sortent pas avec les jeunes de leur âge. C'est toujours avec des hommes un peu plus mûrs, qui ont des ressources financières un peu plus conséquentes. Elles savent qu'en sortant avec des jeunes de leur âge, elles n'auront pas forcément le privilège de recevoir des cadeaux. Les hommes plus riches sont dans la majorité des cas des commerçants. Les commerçants se font beaucoup d'argent, beaucoup de bénéfices. Vous le verrez dans une grosse voiture, vous le verrez distribuer des liasses d'argent à gauche et à droite. Ils ont des moyens de payer une chambre à l'hôtel pour être tranquille. C'est un «phénomène» qui se trouve souvent ici. Les filles préfèrent sortir avec ces hommes-là afin de se faire beaucoup plus de cadeaux, beaucoup plus de fringues. En fait, ces filles font un double jeu. Elles ont à côté leur petit ami officiel, leur "attitré» on va dire. Elles l'aiment beaucoup, on va dire. Mais pour les dépenses et autres choses, elles cherchent un monsieur mûr qui n'est pas de leur âge, le monsieur vieux (cekoroba) quoi. 
Notre recherche nous a confrontées à ce paradoxe. Dans ce contexte de pauvreté et de glorification de la consommation, l'argent joue un rôle proéminent aujourd'hui. Les hommes riches vivent dans une certaine aisance, ils conduisent de grosses Mercedes ou BMW. Ils participent à des joutes d'honneur ostentatoires. Dans cette dynamique, les jeunes femmes qu'ils courtisent font partie intégrante de leur tableau de chasse. Leur virilité est culturellement construite autour de ces conquêtes amoureuses.

En revanche, les jeunes femmes font ce double jeu pour accéder aux accessoires de la culture des jeunes que ni elles-mêmes, ni leurs parents ne sont capables d'acheter. L'argent et les cadeaux qui sont transférés des hommes mûrs et riches vers les filles sont redistribués parmi les petits amis officiels. Dans ce jeu complexe, les jeunes hommes avec peu de moyens doivent rivaliser avec les hommes nantis: «Les jeunes mecs se rendent bien compte qu'ici à Bamako, en Afrique, si tu n'as pas d'argent, tu n'as pas de meuf. Si tu n'as pas d'argent, si tu ne peux pas lui offrir un dîner au restau, tu n'as pas de copine. Si tu ne peux pas lui offrir une jolie robe, tu n'as pas de copine. La majorité des filles sont obnubilées par le matériel» (entretien avec Braddox). C'est justement cette injustice sociale que les rappeurs dénoncent dans leurs chants. C'est grâce à une de ces chansons du répertoire rap que nous avons trouvé l'intitulé du colloque «Chic, chèque, choc». C'est une belle métaphore pour désigner le «phénomène»:

Si t'es pas chic choc alors t'es chèque

y a pas mec qui soit chic choc et chèque

les meufs ne se cassent pas la tête, elles font leur calcul

pour le pécule, elles ne reculent pas mais spéculent

Chanson Sexpéculation de Kar Kaas Sonn (originaire du Tchad)

Les stratégies amoureuses des jeunes femmes s'inscrivent donc dans un double mécanisme social. D'une part, elles tiennent à être belles et attirantes, et, d'autre part, pour être «branchée» elles sortent avec un petit ami. Afin de pouvoir se mesurer sur le plan de l'attractivité, elles dépensent beaucoup de temps et d'argent dans le vestimentaire, les cosmétiques, les tresses et les accessoires. II en résulte que la plupart des jeunes hommes perçoivent les jeunes femmes de leur génération comme matérialistes. Mais comment être à la mode 
quand «certaines familles ne peuvent pas répondre aux demandes matérielles des filles?» nous dit une étudiante en droit âgée de 20 ans. Sans hésitation, elle donne la réponse elle-même: «Si leurs parents ne peuvent pas les satisfaire financièrement, elles seront obligées de pratiquer une autre méthode, quoi ».

\section{Continuité et discontinuité dans les échanges}

La narration de Braddox témoigne du fait que le «bling bling» du hiphop est en concordance avec une prédilection pour l'ostentation dans la société malienne. II nous explique: «Nous avons cette réputation-là, les Africains, nous aspirons à un style de vie ostentatoire, même en dehors du rap, dans la société plus générale. Une fois que la richesse est là, nous aimons la montrer à travers les grosses bagnoles, à travers les grosses baraques, les grosses villas». Selon lui, ce jeu ostentatoire est en étroite relation avec les traditions: "Tout le monde veut paraître aisé, tout le monde veut paraître beau. On se regarde les uns, les autres dans notre société, les voisins, la famille».

Le transfert de cadeaux des hommes vers les femmes fait partie intégrante de cette tradition: «En effet, les hommes faisaient beaucoup de cadeaux, les hommes se tuaient en fait pour rendre leurs épouses très heureuses. Mais la différence avec l'époque antérieure est que les femmes, avant, ne se livraient pas à ce double jeu. Elles étaient fidèles à un seul homme. Le changement c'est qu'aujourd'hui, les filles prennent d'un peu partout» (entretien avec Braddox). En effet, les jeunes femmes savent que les hommes ne sont pas fidèles. Certaines nous ont ri au nez quand nous parlions de fidélité: «Personne n'est fidèle». $\mathrm{Ni}$ les garçons qui fonctionnent selon un repère de polygamie, ni les filles qui mettent en scène les stratégies de partenaires multiples que nous venons de décrire, ne parlent de la fidélité. L'argent est encore une fois un déterminant significatif: «Les garçons, quand ils ont de l'argent, ils peuvent avoir jusqu'à quatre ou cinq filles. Ils peuvent s'offrir de belles voitures. Les filles aiment bien ça » (lycéenne, I 8 ans) - voir également Biaya (200I) et Nyamnjoh (2005) pour le Sénégal.

Aux yeux de Braddox la situation a énormément changé et est devenue dure pour les jeunes hommes. Il attribue les difficultés à la conjoncture actuelle. «Si tous les jeunes avaient la possibilité de travailler et de gagner convenablement leur vie, peut-être qu'il y aurait une 
équité entre les garçons et les filles sur le plan relationnel. Autrement dit, les filles ne seraient pas obligées de soutirer de l'argent aux hommes riches». Mais les stratégies mises au jour par les filles, ce double jeu, peuvent-elles être qualifiées de prostitution? Notre interlocuteur s'adonne à sa propre rupture épistémologique: «À la limite, c'est se prostituer carrément. Mais ce n'est pas vraiment ça, parce que le terme prostitution renvoie à une activité professionnelle. Bon ce que font les jeunes filles, si vous voulez, c'est une autre forme de prostitution. Parce que quand tu ne sors pas avec un seul monsieur, avec un seul mec, s'il y en a deux, trois, quatre, cinq, c'est une autre forme de prostitution. Je pèse mes mots, car toutes les filles ne sont pas comme ça ».

Il y aurait aussi une forme de prostitution à l'insu des filles. «Il y a des filles qui se prostituent sans le savoir. Les vieux les utilisent. Les vieux qui ont réussi, qui sont de grands patrons achètent des cellulaires pour ces filles-là. Ils vont dans des hôtels, ils les appellent. Les filles veulent posséder ces choses-là ». Le dilemme d'appréciation réapparaît. D'une part, on ne désapprouve pas le comportement des filles car la précarité dans laquelle vivent de nombreuses familles fait qu'elles ne peuvent pas offrir aux jeunes une vie (matérielle) à la hauteur de leurs besoins gadgétaires et identitaires. Mais, d'autre part, la polyandrie est une pratique inconnue dans la société malienne et constitue une véritable rupture avec le modèle polygyne. Le grand chamboulement se situe dans le fait que les filles aussi s'engagent dans des relations avec des partenaires multiples.

Le revers de la médaille de la posture ostentatoire des hommes semble être la faillite des jeunes. En termes identitaires, les jeunes hommes ne peuvent pas réaliser ce que l'on attend traditionnellement de l'homme: se procurer un emploi et se marier pour devenir pourvoyeur d'une famille. Certains ont en tête d'aller à l'aventure, partir au loin pour revenir riches. D'autres commencent un business qui se trouve souvent à la limite du licite selon les informations recueillies. Ils savent que sans argent ils ne peuvent pas se permettre de sortir avec une fille. Car selon la coutume, l'homme paie tout lorsqu'il sort avec une fille; la fille s'attend donc à être entretenue. Quand un jeune homme n'a pas (suffisamment) d'argent, il risque de ne pas pouvoir retenir sa copine. II est donc difficile de devenir un «mec branché ». Pour attirer les filles, ils peuvent se lancer dans l'excellence de la danse, par exemple, ou dans l'achat de vêtements à la mode (la figure 
du «chic»). Pour certains, ce rôle assigné de «chic» ou la responsabilité masculine de pourvoyeur les motive à aller travailler. "C'est un moteur quoi. C'est un stimulant parce que si la copine dit carrément "si tu ne travailles pas, on casse quoi et moi je vais chercher ailleurs". Cette situation motive le garçon à aller chercher de l'argent pour subvenir aux besoins de sa fille $»$ (entretien avec Braddox). ${ }^{6}$

\section{Le statut des échanges économico-sexuels au Mali}

De façon générale, et plus particulièrement au Mali, le mariage est un processus transactionnel complexe. Dans certains contextes, les familles concernées payent le prix de la fiancée. Le prix de la fiancée est un transfert - généralement en bétail - des parents de l'époux vers les parents de la future mariée en compensation de la perte de la main-d'œuvre de la fille qui quitte le groupe. Le prix de la fiancée s'observe dans les sociétés pastorales (Peuls, Sonraïs, Sarakolés). Sous une forme plus connue, le paiement de la dot peut consister en un paiement en argent ou en bijoux de l'époux à sa future femme. Dans l'islam, la dot est la propriété inaliénable de l'épouse et sert de soupape de sécurité en cas de divorce. II y a également le trousseau. Le trousseau est la partie matérielle - mobilier, literie - que l'épouse apporte au sein du nouveau foyer. II n'est pas rare de rencontrer une combinaison de ces formes de paiement lors du mariage. D'autant plus qu'au Mali, la négociation de l'union entre les deux familles concernées

6 Pour des raisons de limite d'espace, nous ne pourrons parler ici d'autres figures sociales qui participent au «phénomène», comme par exemple les «bonnes» venues de la brousse pour travailler dans les ménages à Bamako et pour qui une relation amoureuse de type transactionnel est indubitablement un accès «facile» à l'argent. Puis d'autres catégories de femmes sont également représentées au niveau discursif comme étant actives dans des rapports sexuels à «but commercial»: les immigrées étrangères (Guinéennes, Nigérianes, Ghanéennes), les filles «sans famille» - sous-entendu issues de familles divorcées. De plus, il y a les «deuxièmes bureaux», c'est-à-dire des femmes riches qui s'engagent avec des hommes moins fortunés, dont les figures emblématiques sont les Mama Benz, riches commerçantes dans divers pays d'Afrique de l'Ouest. Que dire également de la communauté des «expats» ou des touristes qui sont sources d'argent et dont la seule présence induit de nouvelles dynamiques économico-sexuelles. Ces quelques exemples témoignent de l'étendue du phénomène des transactions économico-sexuelles. 
respecte différentes étapes (pour une description détaillée voir Brand 200I, 67-I02).

L'historien Kamian nous apprend que, dans la société traditionnelle, les filles et les garçons étaient donnés en mariage dès leur naissance dans le cadre d'arrangements familiaux plus larges qui contribuaient à la reproduction sociale du groupe. II attire notre attention sur l'absence du statut de célibataire: «Du fait que l'on était promis en mariage dès sa naissance, il n'y avait pas de célibataires dans nos sociétés traditionnelles ». Cette promesse de mariage dès la petite enfance avait un effet dissuasif en termes de libertinage: «Le fait de draguer la femme de quelqu'un d'autre était extrêmement mal vu et on s'exposait au risque de recevoir un sort de type impuissance sexuelle (dana)» (idem). Dans d'autres groupes sociaux, «quelqu'un qui était coupable» se voyait devenir l'objet d'une mise en accusation publique. Si une telle aventure finissait par une grossesse, la fille était expulsée du village.

De nos jours, avec le changement de la structure démographique et avec l'urbanisation et l'émergence des mariages par amour, la catégorie sociale de célibataire est apparue. Il s'agit de personnes non mariées, généralement jeunes, et sexuellement actives. La durée de cette étape de vie est variable et dépend des possibilités qu'ont les jeunes, surtout les jeunes hommes, de créer les conditions nécessaires pour entrer dans le mariage (fin d'une formation, obtention d'un emploi, achat d'une maison). Du point de vue de la santé reproductive, cette catégorie émergente nécessite une attention spéciale. Cependant, les services ne sont pas toujours préparés à apporter des conseils et des soins à des jeunes dont le comportement leur semble moralement condamnable. Notre recherche s'inscrit dans un projet plus large qui vise à (faire) comprendre la logique sous-jacente de ces comportements. Avant de condamner ces comportements pour des raisons normatives, il est important de savoir qu'ils s'inscrivent à la fois dans une durée historique et qu'ils relèvent d'une culture de jeunesse émergente.

\section{Discussion}

Dans différentes sociétés, la sexualité des femmes est représentée comme leur «capital», leur «terre» ou leur «trésor», etc. (Tabet 
200I). La sexualité étant considérée de cette façon, l'engagement des femmes dans des rapports sexuels constitue indéniablement un moyen direct ou indirect pour accéder aux ressources. C'est ainsi que, dans les sociétés préindustrielles, le mariage procurait aux femmes l'accès à la terre, de même que dans les sociétés industrielles le mariage permettait aux épouses d'accéder à un revenu. Dans les sociétés agraires africaines, la division sexuelle du travail, considérée comme complémentaire, permettait aux femmes de générer des revenus propres par la vente de produits cultivés sur les parcelles dont elles avaient l'usufruit. L'avènement des modes de production capitalistes est allé de pair avec l'émergence de la figure du mari pourvoyeur de revenus pour la famille et dont l'épouse dépendait économiquement. Cette configuration familiale est devenue le modèle de référence stéréotype tout au long de la colonisation et pendant l'ère du développement ${ }^{7}$. Les hommes étaient considérés comme seuls pourvoyeurs au sein des familles, et les femmes comme des dépendantes économiques.

Dans cette même logique, les hommes gagnaient en virilité en donnant des cadeaux à leurs épouses sous forme de vêtements, de chaussures, de voitures, de maisons ou d'autres gadgets (téléphone portable, moto,...). À l'opposé de cette virilité ostentatoire, s'est construite la féminité beauté. Les femmes aiment recevoir des cadeaux et gagnent en statut social par l'affichage d'attributs «luxe-beauté». La vieille génération énonce avec fierté et modestie qu'auparavant, si le mari avait les moyens, il pouvait donner des cadeaux à son épouse, mais que s'il n'avait pas les moyens, l'épouse comprenait et acceptait.

Le fait de conceptualiser tout acte sexuel en une relation transactionnelle nous pousse à "troubler $\rangle^{8}$ la distinction entre une relation sexuelle conjugale normale et prostitutionnelle, entre une femme dite décente et une femme dénommée «pute», et entre la sexualité comme ressource reproductive et/ou productive. Contrairement à ce qui se pratiquait par le passé au Mali, les jeunes filles ont actuellement

7 C'est ce modèle de la femme économiquement inactive qui a structuré les interventions du développement dans le secteur agricole en Afrique. C'est ce que Ester Boserup (1970) avait appelé le processus de housewifization des femmes africaines.

8 Par analogie avec le titre de l'ouvrage de Judith Butler (1999) Gender trouble: feminism and the subversion of identity (publié en français en 2006 sous le titre Trouble dans le genre. Le féminisme et la subversion de l'identité). 
plus de libertés de choisir leur(s) partenaire(s). «Les filles vont avec, je ne dirais pas n'importe qui, mais en tout cas, il y a plus de choix, tandis que dans le passé, dans la majorité des sociétés soudanaises, c'étaient les parents qui choisissaient pour les filles, pour les enfants. Tout ça c'est fini. II y a la liberté de choix », nous dit sur un ton nostalgique l'historien Kamian. Et il ajoute: «Aujourd'hui, l'amant des jeunes filles est devenu un peu son souteneur ».

Le jeu est complexe. D'un côté, les jeunes filles profitent de ces transactions pour être à la mode. De l'autre côté, elles savent très bien qu'il n'est pas bienséant de demander de l'argent. «Je ne demande pas à un homme de me donner quelque chose. C'est à lui d'avoir la conscience de me donner, ce n'est pas à moi de lui demander»» (lycéenne, 18 ans). L'échange d'argent dans une relation fausse le rapport de force: «Quand même, si tu prends l'argent de quelqu'un tu es obligée de te soumettre à ce qu'il veut» (étudiante en droit, 20 ans). En fin de compte, le "phénomène» est la résultante d'un processus de mise en scène actuelle de masculinités et de féminités multiples.

Le "phénomène» permet de voir cet aspect ambivalent du comportement de la génération actuelle de jeunes femmes. Leurs corps et leur sexualité sont devenus un instrument efficace pour construire une nouvelle identité féminine. Cette identité se construit au sein d'une culture de jeunes mondialisée imbriquée dans la tradition ostentatoire africaine:

II n'est pas difficile d'avoir trois à quatre hommes, et parmi eux, il peut $y$ avoir un homme que tu aimes vraiment. Les autres ce sont des hommes que tu aimes pour ce qu'ils ont, mais pas pour le vrai amour. Ça fait partie de la démarche des filles qui sont matérialistes. Elles ont plus de trois ou quatre hommes. Il y a des hommes qui leur donnent de l'argent, et d'autres qu'elle aime vraiment. (lycéenne 18 ans)

Le désir de satisfaire les aspirations matérielles, ainsi que le désir d'affection, semblent être sous-entendus dans les projets de beaucoup de jeunes femmes. De nombreuses filles sont conscientes de leur jeunesse et de leurs aspirations identitaires de jeunes Maliennes. Leur accession au statut de sujet de leur histoire et de maîtresse de leur corps est en train de bouleverser profondément le système de genre. 


\section{Conclusion}

Peut-être ça arrange beaucoup de gens aussi, c'est pour cela que l'on n'en parle pas. Ceux qui sont en charge de réprimer font ça, encouragent ça. (AS, homme 40 ans)

La prolifération du «phénomène» ne peut s'arrêter tant qu'il y aura des gagnants, aussi bien du côté des hommes jouissant de l'argent-pouvoir", que du côté des jeunes femmes qui deviennent sujettes de leur histoire, et indirectement du côté des jeunes «mecs branchés» qui profitent de la redistribution des richesses via leurs petites copines. La nostalgie et le désarroi s'observent parmi les personnes qui ont été socialisées dans un univers moral traditionnel, parmi les parents qui n'arrivent plus à assouvir les besoins de leurs enfants qui sont exposés aux modèles de consommation présentés par les images venues d'ailleurs et en dernier lieu parmi les opérationnels du développement de la santé reproductive qui propagent le message de l'abstinence, de la fidélité et du préservatif. Le «phénomène » n'est dès lors plus seulement explicable par la pauvreté, mais également - et peut-être plus spécifiquement - par l'abondance des richesses dans un «système monde » à plusieurs vitesses qui profite à certains hommes et - ce qui n'est pas à négliger - à l'émancipation des femmes.

\section{Références bibliographiques}

Biaya, T. K. 200I. Les plaisirs de la ville: masculinité, sexualité et féminité à Dakar (I997-2000). African Studies Review. 44(2) : 7I-85.

Boserup, E. 1970. Woman's role in economic development. London: George Allen \& Unwin Ltd.

Boye. A.K, K. Hill, S. Isaacs, D. Gordis. 199I. Marriage law and practice in the Sahel. Studies in Family Planning, 22(6): 343-349.

Brand, S. 200I. Mediating means and fate. a socio-political analysis of fertility and demographic change in Bamako, Mali. Leiden: Brill, African Social Studies Series, Vol.I

9 La distribution du revenu au Mali nous montre que $56 \%$ du revenu national est généré par les $20 \%$ les plus riches, tandis que les $20 \%$ les plus pauvres ne génèrent que 4,6\% (http://www.nationmaster.com/country/ml-mali/eco-economy) . II $\mathrm{y}$ a donc une catégorie de Maliens très riches qui participent à ce système de redistribution des richesses par les logiques ostentatoires et identitaires. 
Butler, J. 1999. Gender Trouble: Feminism and the Subversion of Identity. New York; London: Routledge

Butler, J. 2006. Trouble dans le genre. Le féminisme et la subversion de l'identité. Paris: Éditions La Découverte.

Grange Omokaro, F. 2009. Féminités et masculinités bamakoises en temps de globalisation. Autrepart. 49: 189-204

Hertrich, V. 2007. Nuptialité et rapports de genre en Afrique. Tendances de l'entrée en union, 1950-1999. In Genre et sociétés en Afrique. Implications pour le développement. (Dir.) T. Locoh. 28I-308. Paris: INED, Les Cahiers de I'INED 160.

Lévi-Strauss, C. 1949. Les structures élémentaires de la parenté. Paris: PUF

Malinowski, B. 1922. Argonauts of the Western Pacific: an account of native enterprise and adventure in the archipelagoes of Melanesian New Guinea. London : G. Routledge; New York: E.P. Dutton

Mauss, M. 1923. Essai sur le don. Forme et raison de l'échange dans les sociétés archaïques. Année sociologique, 1923-1924.

Nyamnjoh, F. B. 2005. Fishing in troubled waters: disquettes and thiofs in Dakar. Africa. 75(3): 295-324

Reysoo, F. 2009. De vermarkting van vrouwenlichamen in Bamako, Mali. Tijdschrift voor Vrouwenstudies. 12(4) : 65-70.

Rubin, G. 1975. The traffic in women: notes on the 'political economy' of sex. In Toward an Anthropology of Women. (Ed.) R. R. Reiter. 157-2 I 0. New York: Monthly Review Press.

Tabet, P. 1987. Du don au tarif: les relations sexuelles impliquant une compensation. Les Temps Modernes. 42(490) : I-53.

- 200I. La grande arnaque: l'expropriation de la sexualité des femmes. Actuel Marx. $\mathrm{N}^{\circ} 30$ : I3I-I52 (numéro spécial sur Les rapports sociaux de sexe).

—. 2004. La grande arnaque: sexualité des femmes et échange économico-sexuel. Paris: L'Harmattan.

UNFPA (United Nations Population Fund). 1994. Programme d'action adopté à la Conférence internationale sur la population et le développement, Le Caire, Septembre 1994. 



\title{
L'amour, le sexe et l'argent au Maroc: une sexualité dans tous ses états
}

\author{
Mériam Cheikh*
}

\section{Introduction}

Au Maroc, les hommes et les femmes manifestent aujourd'hui des amours variées et souvent monnayées. Toutes ces relations sont stigmatisées et réduites à la sphère prostitutionnelle en raison de la circulation monétaire à laquelle elles donnent lieu. Pourtant, elles sont bien plus complexes que la relation sexuelle marchande telle que nous la connaissons en Europe. En effet, à part dans le cas du travail sexuel, nous avons parfois affaire à des relations amoureuses où la transaction économique facilite et renforce la liaison. Loin de nous situer dans des relations uniquement marchandes, nous nous trouvons au cœur de liens aux intérêts complexes où s'enchevêtrent argent, sexe et amour. Ces différentes manières de faire font partie de ce que l'ethnologue Paola Tabet (2004) qualifie d'échange "économico-sexuel ». Le premier élément de cette expression se caractérise par les conditions de ces prestations de services négociées et limitées dans le temps. Le second se rapproche d'un type de conjugalité plus classique à cause du flou qui le caractérise et de l'amalgame entre

Anthropologue, Université libre de Bruxelles, Meriam.Cheikh@ulb.ac.be

Cheikh, M. 2012. L'amour, le sexe et l'argent au Maroc: une sexualité dans tous ses états. In Chic, chèque, choc. Transactions autour des corps et stratégies amoureuses contemporaines. 92-105. Actes des colloques genre et développement. Berne: DDC-Commission suisse pour l'UNESCO; Genève: IHEID. 
l'amour ou l'affection, le sexe et le plaisir et l'argent ou les dons qui s'y jouent. Comme nous allons le voir, il n'est pas évident de délimiter clairement chacune de ces pratiques qui peuvent déborder de leurs frontières et se chevaucher.

Au Maroc, ces «transactions amoureuses» ont lieu dans des contextes essentiellement urbains où l'âge du premier mariage est en net recul pour les deux sexes: $3 \mathrm{I}$ ans pour les hommes et 27 ans pour les femmes en 1999 (Direction de la statistique 2005), et où l'on observe un processus d'individualisation professionnel: les femmes travaillent davantage, restent plus longtemps célibataires et partagent un appartement avec d'autres femmes quand elles migrent ou désirent marquer une rupture avec leur famille. Cette pratique de la colocation constitue un lieu de redéfinition des modalités de féminité et de masculinité en ville car elle crée un espace qui renforce l'autonomie et véhicule des valeurs différentes de celles du système familial traditionnel. Elle permet aux femmes de choisir leurs partenaires et de gérer conjoints successifs ou partenaires multiples. Par conséquent, de nouvelles perceptions du couple se mettent en place, dépassant le seul cadre de l'institution matrimoniale. Cette situation s'observe particulièrement dans les classes populaires urbaines. Loin de définir ou de légitimer d'autres normes conjugales, elle stimule la transformation des identités sexuelles qui demeurent tout de même fragiles en raison d'enjeux de réputation.

Dans cet article, je me propose d'expliquer ces dynamiques en marche, de présenter cette sexualité hors normes et de décrire de manière succincte les différentes facettes de ces échanges «économico-sexuels» qui se situent à la frontière du travail du sexe et des «transactions amoureuses». Je me suis appuyée, pour cela, sur les premiers résultats d'une recherche menée à Casablanca dans le quartier de Hayy Hassani.

\section{Quelle sexualité aujourd'hui au Maroc?}

Alors que la pratique sexuelle existe bel et bien en dehors du mariage et qu'elle n'est pas anecdotique dans les milieux populaires sur lesquels je travaille - pas plus qu'elle n'est d'ailleurs inexistante dans les autres milieux -, cette sexualité hors institution est définie comme marginale. En effet, on remarque qu'en dépit de l'importance prise par 
ce phénomène, la morale sociale ne l'intègre toujours pas dans ses discours et cela bien qu'elle connaisse aussi des transformations. On assiste ainsi à un décalage entre les discours et les pratiques. Dès lors qu'elle ne peut plus être cachée, la sexualité pratiquée en dehors des normes est vilipendée et un seul des protagonistes - en l'occurrence la femme - est stigmatisé. On en veut pour preuve la situation des mères célibataires qui se trouvent complètement marginalisées lorsque survient une grossesse hors mariage. Ainsi, Aïcha (28 ans lors de notre première rencontre en mars 2006), jeune mère originaire d'une famille paysanne de Beni Mellal, a été rejetée par ses frères quand ceux-ci ont appris la nouvelle de sa grossesse. Elle m'a confié que ses sœurs lui avaient expliqué qu'elles avaient toutes eu des relations avant le mariage, mais qu'elles ne comprenaient pas comment elle avait pu tomber enceinte.

Par ailleurs, cette sexualité hors institution est considérée comme moderne parce qu'elle s'opposerait ou se substituerait aux valeurs traditionnelles et conservatrices. En réalité, le rapport qu'elle entretient avec le conservatisme est plus complexe et ces deux ensembles normatifs se concurrencent aussi bien qu'ils s'enchevêtrent. L'évolution de la sexualité, au Maroc, doit donc moins être analysée en termes de lutte entre deux modes culturels, l'un moderne et l'autre traditionnel, qu'en terme d'évolution des pratiques sous l'effet de facteurs culturels et socio-économiques. Ces éléments, qui engendrent de nouvelles situations telles que le célibat prolongé, banalisent ces expériences sexuelles pré-maritales et hors normes.

Ainsi, même si le mariage demeure l'idéal social à atteindre pour prétendre à la respectabilité, mais aussi pour cadrer avec un imaginaire collectif véhiculé quotidiennement par une multitude d'images et de sons, il n'en reste pas moins que les femmes et les hommes s'expriment sexuellement. Cependant, cette banalisation est sournoise et les raisons de cet état de non-dit, de flou, dans lequel demeure la sexualité doivent aussi être recherchées du côté de l'État qui réprime aléatoirement par la loi ces pratiques'. Comme le soulève Abdessamad Dialmy, en même temps qu'il criminalise ces pratiques, il les légitime à travers

L'article 490 dit: «Sont punies d'emprisonnement d'un mois à un an toutes personnes de sexes différents qui, n'étant pas unies par les liens du mariage, ont entre elles des relations sexuelles ». 
ses services de santé: prévention SIDA², contraception et préservatifs distribués aux non mariés. L'espace sanitaire devient un refuge pour cet État qui prohibe et cautionne en même temps. Les mécanismes de cette "politique informelle» (Dialmy 2005) de la sexualité sont similaires à ceux de son acceptation sociale, également informelle. Les deux sphères se caractérisent par la culture du non-dit. La signification du délit de débauche (fasad) demeure aléatoire. Aussi, les discours d'ajustement se multiplient. Une même personne peut condamner, tout en l'exerçant, une sexualité non institutionnelle.

\section{Amour, sexe et argent}

C'est dans le cadre de cette sexualité non institutionnelle que de nombreux échanges sexuels entre hommes et femmes donnent lieu à une rétribution de la part de l'homme. Aussi, même lorsque aucune activité sexuelle n'est pratiquée, remarque-t-on - et cela indépendamment de l'origine sociale - qu'il incombe au partenaire masculin de payer, d'inviter sa copine, de lui offrir des cadeaux, sachant que l'absence de ces dons - comme d'ailleurs leur convoitise explicite - est mal considérée. À ce propos, une jeune fille, qui s'exprime sur le forum des jeunesses socialistes, explique:

(...) Je vois un mec qui a une voiture qui se fringue bien... il me plaît! Je vous rappelle qu'au Maroc, un mec bien est celui qui assure à une femme (maison), (voiture) et plus quelques affinités. $\mathrm{Ce}$ mec me plaît parce que je pense, parce que ma famille, la société m'ont appris depuis toujours, que c'est ça le type bien. J'essaie de le charmer, de sortir avec lui. Suis-je pour autant une prostituée? Ce mec, vu qu'il peut se permettre des choses, des petits tours dans des endroits sympas, il me plaît encore plus parce que je vis de nouvelles choses avec lui, même si elles sont

2 En 2006 comme les années précédentes, l'Association de lutte contre le SIDA (ALCS), en partenariat avec le Secrétariat d'État à la jeunesse, a reconduit sa prévention auprès des jeunes des colonies de vacances bénéficiaires du programme «Vacances pour tous». Signalons également la prévention sur le SIDA menée en 2007 par l'ALCS et qui a permis la diffusion sur toutes les ondes d'une parole libre sur la sexualité des jeunes, le préservatif, l'homosexualité et la prostitution. 
matérielles. Suis-je pour autant une prostituée? La prostitution s'arrête à des femmes ou hommes monnayant quelques actes sexuels pendant une période limitée. Alors, il faudrait peut-être arrêter de traiter toutes les femmes de $\mathrm{p}^{* * * *} !^{3}$

Ce témoignage - tout en soulignant le décalage qui existe entre l'idée que l'on a de la socialisation des jeunes filles avec l'autre sexe, c'est-àdire le fait de sortir avec un homme possédant des ressources conséquentes, et la critique de ce comportement - met précisément le doigt sur l'amalgame entre prostitution et relations intimes/affectives monétarisées.

À travers cet extrait, on s'aperçoit que la relation amoureuse représente ici à la fois un moyen de consommer et de se divertir et une façon de s'entraider dans les milieux pauvres. En effet, la transaction amoureuse s'observe le plus souvent dans les populations de personnes prolétaires émigrées, originaires des campagnes avoisinant les grandes villes. Analphabètes ou ayant reçu une éducation primaire, ces femmes font le ménage dans des cafés ou dans des maisons, travaillent dans les usines de textile, dans le domaine de la restauration ou du sexe et vivent loin de leurs parents dans des chambres qu'elles partagent à plusieurs. Elles côtoient donc, en toute liberté, des hommes qui vivent, eux aussi, en colocation dans les mêmes quartiers ou à proximité. Cette promiscuité favorise les rapports entre les sexes autant qu'elle les rend visibles, et cela dans des milieux qui connaissent souvent un «regain » de conservatisme religieux identitaire. Les couples se font et se défont au gré des amours partagés et des affinités. Les monogamies sérielles et le concubinage s'instaurent, reproduisant ainsi le schéma des relations maritales.

\section{Du pragmatisme dans l'être en couple}

Le cas de Khadija est symptomatique de ces relations. Mère célibataire de 25 ans au moment de l'entretien en mars 2006, Khadija quitte très jeune sa campagne natale au sud de Casablanca à l'initiative de ses parents qui la placent comme femme de ménage dans une famille. Depuis son adolescence, elle travaille comme domestique chez une

3 Intervention sur «Réputation des Marocaines», forum Altavista, 21 octobre 2004: http://forums.avmaroc.com/archive/o_t_t_1063_start_0_index.html 
femme qui l'envoie illégalement chez sa fille aux Pays-Bas pour qu'elle s'occupe de l'entretien de la maison et des enfants. Après un bref séjour dans ce pays qu'elle ne supporte pas et une tentative de fugue, elle retourne à la campagne puis revient à Casablanca où elle s'installe chez sa tante qui habite dans le quartier populaire de Hayy Hassani ${ }^{4}$. Très vite, elle enchaîne les petits boulots dans le ménage. En raison de ses fréquentations masculines peu appréciées, sa tante, qui veut préserver sa réputation aux yeux de la famille de son mari, la met en garde. Khadija quitte alors le foyer pour s'installer en colocation à I-ouilfa, un quartier similaire et proche de celui où habite sa tante. Elle abandonne sa relation précédente et rencontre, par l'intermédiaire d'une amie, Mustapha qui habite également Hayy Hassani et qui y travaille en tant que vendeur de vaisselle de rue. L'idée de sortir avec Khadija, bien qu'elle soit aussi la compagne de son ami, enthousiasme Mustapha: ils seront, en effet, désormais quatre à sortir et à partager de bons moments. Au fil de leur relation, Khadija partage ses journées et ses nuits entre la chambre qu'elle loue avec des filles et celle de son petit copain qui vit seul. Avant de tomber enceinte, elle fréquente durant un an et demi celui qu'elle qualifie d'ikhwani, c'est-à-dire de «bigot». Elle restera avec lui jusqu'à son accouchement. Mustapha n'est pas le premier homme avec qui elle a eu des rapports sexuels. Khadija m'explique avoir de très bons souvenirs de Mustapha et ne pas se sentir lésée car il ne lui a jamais promis le mariage. En revanche, paradoxalement, son compagnon s'est opposé à l'avortement pour des raisons religieuses. Leur relation se passe bien: ils s'aiment, ils sortent, vont s'asseoir dans des cafés où il lui offre des limonades et du jus de fruit. Il l'aide à régler son loyer, lui achète des vêtements, lui offre de la vaisselle, en bref, lui fournit ce dont elle a besoin et ce qu'elle désire. Alors qu'elle travaille à proximité du logement de Mustapha, elle finit par passer la majeure partie de son temps libre dans sa chambre dont elle possède les clefs. Au moment où j'interviewe Khadija, Mustapha hésite à venir lui rendre visite et à voir son fils. II refuse cependant catégoriquement son projet de quitter le quartier.

4 Ce quartier est, par ailleurs, connu pour l'audience qu'y ont le Parti de la justice et du développement (PJD) et les associations islamistes. 
(...) II m'aidait, il me payait le loyer. C'est son bon côté. Je lui disais: «Il me faut, je veux acheter ça, ci», il me disait «N'achète rien, je vais te donner». Bon, il m'a donné de la vaisselle, les vêtements, il me les achetait lui. (...) Mais j'avais honte. Je ne voulais pas lui dire: «Il me faut ça ou ci». Si je voulais acheter des choses, je lui disais: «Voilà, je veux acheter», pour qu'il comprenne luimême et que je n'aie pas à le lui dire directement.

Dans cette relation, l'amour se mêle au sexe mais aussi à l'argent. Cette dimension est importante pour Khadija qui a du mal à s'en sortir. Sans le formuler clairement lorsqu'elle me décrit les conditions dans lesquelles elle a rencontré Mustapha, elle explique qu'elle accompagnait son amie tandis que celle-ci se rendait chez son copain qui lui payait son loyer. Khadija s'inscrit donc dans une pratique courante de l'échange monétaire chez ces jeunes couples pauvres. Toutefois, elle ne se considère pas comme une prostituée. Au contraire, elle tient à marquer la différence entre elle et certaines de ses colocataires qui «sortent». Le verbe "sortir», en arabe I-khrij, est un euphémisme pour désigner l'activité prostitutionnelle au Maroc. Sa relation avec Mustapha n'a rien à voir avec la vente de sexe que pratiquent de nombreuses filles qu'elle connaît et qu'elle qualifie de «malchanceuses » ou de «filles pas bien». Elle n'emploie jamais le terme de prostituée, inexistant en marocain, ni celui de «pute» qui est, lui, couramment utilisé. Ce qui la différencie de ces femmes réside moins dans l'argent reçu de la part d'un homme que dans la multiplicité des partenaires, la simultanéité des relations et la transparence de l'échange. Le fait de réclamer ostensiblement de l'argent à différents partenaires donne une image négative de la femme, estime Khadija. Quand elle a besoin ou envie de consommer, elle se contente de le suggérer à son compagnon. Il semblerait qu'il soit nécessaire de maintenir un non-dit pour que la relation continue d'être considérée comme «normale». À ce propos, lors d'un entretien, une professionnelle m'expliquait qu'elle ne demandait jamais à être payée avant parce que l'homme avait l'impression que la relation «n'avait plus de sens».

C'est ce qu'évoque également Nadia, mère célibataire dont l'enfant a été volé à la naissance et qui a pratiqué le travail du sexe, entre embauche et licenciement à l'usine. Aujourd'hui, elle a abandonné ses relations multiples pour ne rester qu'avec un seul homme qui paie son 
loyer et ses courses et lui a promis le mariage en échange de sa fidélité. Elle explique préférer cette situation au fait de passer d'un homme à l'autre et de s'exposer ainsi aux maladies en tout genre et à l'instabilité. Toutefois, elle avoue avoir envie de reprendre un emploi pour compléter ses revenus qu'elle trouve insuffisants, mais son copain refuse de la voir travailler dans des cafés. Nadia reste donc avec lui en attendant de voir si leur relation aboutira à un mariage. Toutefois, elle garde la tête froide et déclare détester les hommes et leurs mensonges. Ce n'est pas l'appât du gain qui la retient auprès de cet homme puisqu'elle pourrait reprendre ses activités, mais l'entraide financière et la promesse d'une vie dans les normes. Bien qu'elle soit désenchantée, cette normalité conjugale la séduit encore. Nadia est tout de même consciente que sa situation en ville - en l'occurrence celle d'une femme seule qui vit en colocation avec d'autres femmes - la fragilise. En effet, les femmes ont souvent affirmé que leurs petits copains avaient du mal à leur faire confiance en raison de leur condition locative qui les éloigne de la vigilance des proches et ne sauvegarde pas leur réputation.

L'«imagerie conjugale» (Vidal 1977) traditionnelle persiste donc aussi bien chez ces hommes que chez ces femmes qui s'efforcent de jongler entre la nécessité de gérer financièrement leur vie en détournant une partie de l'argent des hommes et celle de protéger leur estime d'elles-mêmes en tentant, autant qu'elles le peuvent, de se rapprocher des exigences normatives édictées par la société. Dès lors, la prise de distance de ces prescriptions devient transitoire et s'inscrit dans une parenthèse qu'il convient de refermer en trouvant un mari ou un amant unique, le cas échéant. C'est notamment le cas d'Asmaa, 24 ans, originaire de Casablanca, qui vit depuis plusieurs années des transactions amoureuses, à la fois par choix et par plaisir. Ses frères ayant émigré en Italie, elle vit seule avec ses parents et travaille dans un supermarché. L'argent que lui donnent ses amants lui permet de s'habiller, de se coiffer, de se maquiller et de sortir en attendant que son fiancé l'épouse et qu'elle puisse construire un foyer «normal». Bien évidemment, cette recherche du paradis conjugal appartient au registre de l'idéal puisque les identités féminines et masculines évoluent et ne correspondent plus aux discours. En effet, dans ce contexte de précarité, les mariages n'ont pas lieu et les logiques conjugales hors normes continuent de se transformer. 


\section{De l'amante financée à la travailleuse du sexe}

Les cas de Ghizlaine et Samiha apportent une autre perspective sur ces amours et aventures monétarisés. Ghizlaine, 26 ans, est née à Casablanca et est originaire de Marrakech. Elle vit à l-ouilfa et alterne heures de ménage dans un café, emploi à l'usine et travail du sexe. Elle jongle ainsi entre différents types de partenaires et de pratiques. Elle peut avoir des clients qu'elle ne revoit pas et qui la paient pour une passe - ce n'est cependant pas ce qu'elle préfère - ou alors entretenir une relation avec plusieurs partenaires ${ }^{5}$ - dont son amoureux - qui lui fournissent régulièrement argent, vêtements, nourriture et l'invitent dans des lieux de divertissement. Dans son portable, elle dispose d'un répertoire qu'elle renouvelle en retournant de temps à autre dans les cafés et dans les pubs du centre ville de Casablanca. Ghizlaine sort tous les jours pour faire des rencontres, gagner de l'argent en travaillant ou en nouant des relations intimes et sexuelles, mais aussi pour se divertir, retrouver des copines, échapper à l'étroitesse du foyer familial qu'elle a réintégré avec son fils depuis son divorce. À côté de ces plaisirs matériels, Ghizlaine évoque le plaisir sexuel qu'elle a avec ses réguliers dont elle apprécie la compagnie. Ce plaisir se renforce d'ailleurs au fil des dons et des attentions de ses «amants payants». Son cas incommode: il dérange certaines catégories d'entendement car il révèle combien il est difficile d'établir des catégories de pratiques distinctes les unes des autres.

Le Gabonais il me choie bien et il m'aime. Tu vois si quelqu'un te dit qu'il t'aime, il te dit «I love you», «mon bébé», etc., toi aussi tu vas lui dire que tu l'aimes. Si tu lui dis, il va bien te choyer, bien s'occuper de toi. (...) II s'occupe bien de moi et je prends bien mon pied. II m'achète des vêtements à 350 dhs, 400 dhs. Chaque semaine, il m'achète des vêtements. Avec lui je prends mon pied. Avec mon copain aussi, le mec du taxi aussi.

Samiha a $3 \mathrm{I}$ ans. Elle est originaire de Casablanca et vit à l-ouilfa. Elle a été mariée pendant treize ans à un militaire dont elle a divorcé en 2002. Elle a ensuite commencé à travailler dans une usine de textile. Alors que son salaire de $3 \mathrm{dhs} /$ heure ne lui suffisait pas pour nourrir ses quatre enfants, payer son loyer et couvrir ses frais de transport,

5 De l'ordre de trois au moment de l'entretien. 
elle a décidé d'arrêter en 2003 et de commencer à «sortir». Elle est une des rares femmes que j'ai rencontrées qui se qualifie de "pute» (qahba) et qui affirme clairement les raisons de ses relations avec les hommes, c'est-à-dire uniquement échanger du sexe contre de l'argent. Elle refuse d'entendre parler d'amour et prétexte que les seules véritables relations sont celles qui se nouent auprès d'hommes «puissants» et «capables». Lorsqu'elle décrit son activité, elle insiste sur la négociation du temps et sur l'idée de service limité. Ainsi, contrairement à Khadija, à Nadia et, dans une certaine mesure, à Ghizlaine, Samiha ne se trouve pas dans des arrangements économico-amoureux flous mais dans une logique clairement définie, celle du travail du sexe.

C'est moi qui ai renoncé à la pension des enfants car je ne veux pas qu'il me donne quoi que ce soit. C'est un drogué, un alcoolique et je préférais renoncer qu'avoir encore affaire à lui. En 2003, je me suis lancée dans les sorties («atitha dakka l-bab», j’ai donné un bon coup à la porte). J'ai rencontré des filles qui habitent à côté de chez moi, c'est mes voisines qui m'ont dit de sortir. Je ne sors que la nuit vers $2 \mathrm{Ih}-22 \mathrm{~h}$. Je m'occupe de mes enfants, je les fais dormir et je sors ensuite. Je vais dans le centre-ville. Je ne vais que dans les bars. C'est 100 dhs la passe et 200 dhs la nuit. Je peux en faire plusieurs dans la nuit ou alors je peux passer la nuit avec un seul, ça dépend. Certains de ma famille savent ce que je fais mais je m'en fous, c'est pas eux qui me nourrissent et qui nourrissent mes enfants alors, ils n'ont rien à dire. J'ai pas de petit copain et je suis bien toute seule, je n'ai pas d'amour sauf l'amour pour l'argent (hub al-mal). Les gens pensent que je suis une pute mais je m'en fous. Lorsque je marche, je ne les vois pas.

Du travail sexuel à la relation amoureuse financée en passant par l-khrij ou «sortie», les différentes femmes présentées précédemment sont impliquées soit dans un seul type de rapport soit dans plusieurs, de manière simultanée ou successive. À part avec Samiha, on remarque qu'il est difficile de classer les activités de ces femmes dans la catégorie du travail du sexe. Khadija et Nadia entretiennent des relations exclusives alors que Ghizlaine et Asmae, en dehors de leur relation amoureuse, ont des échanges qui oscillent entre le travail du sexe et les aventures financées de plus longue durée. 


\section{Définition des pratiques et des activités}

Si mes interlocutrices ont eu recours au mot "prostituée» dans les rares entretiens que j'ai menés en français, celles avec qui je discutais en arabe n'ont jamais utilisé aucun terme analogue lorsque je leur demandais d'évoquer leur activité sexo-marchande. En dialecte marocain, l'expression "prostituée» n'existe pas et le terme «baghî» qui y correspond appartient à la langue classique et n’a pas été intégré. En revanche, le mot injurieux «qahba» ("pute»), qui condamne moralement et stigmatise une personne, est employé. La qahba peut s'appliquer indistinctement à toutes les femmes. Celles qui sont concernées l'utilisent parfois dans des contextes amicaux. Pour définir l'activité en tant que telle, le dialecte a recours au verbe tat-fsad, c'est-à-dire «elle se corrompt». Plus rarement, on peut entendre aussi l'occurrence 'âmilat al-jins («travailleuse du sexe»). Empruntée aux mouvements associatifs européens, cette expression est employée uniquement par l'ALCS. Lors des séances de sensibilisation aux maladies vénériennes, son usage faisait souvent rire les membres de l'assistance qui considéraient qu'elle ne s'accordait pas avec l'idée qu'elles-mêmes se faisaient de leurs activités, qu'elles rangeaient dans la catégorie du «tout» plutôt que dans celle du travail. Face à une telle carence terminologique, ce bricolage définitionnel n'est pas étonnant.

\section{L-khrij ou « sortie »:}

\section{divertissement, débrouillardise ou travail}

Nous avons constaté que les femmes qui s'inscrivent dans la prostitution ou qui accumulent les relations monétarisées simultanément (Asmae, Ghizlaine et Samiha) qualifient leurs activités de khrij ou «sortie». Elles ont recours à ce terme qui, en plus de désigner ce type de transaction, évoque le fait d'aller au café, boire de l'alcool ou faire des passes. Le reste de la société utilise également cette expression - ou plutôt l'occurrence très stigmatisante "elle sort dans la rue» - pour signifier la déviance de cet acte. Dire d'une fille ou d'une femme qu'elle «sort dans la rue» renvoie toujours à une pratique de la sexualité hors norme. En effet, l'idée de khrij s'apparente au divertissement dans des espaces mixtes, ce qui, dans le discours social, projette une image négative de la femme en question. Des équivalents plus suggestifs à tan-khrij 
(«je sors») existent: on retrouve tan brek ou tan glass (littéralement «je m'assois») qui renvoient à la présence des femmes dans des cafés spécifiquement masculins. Si le fait de travailler dans ce genre d'endroit, même en tant que femme de ménage, est stigmatisant, s'y asseoir sans but précis relève de la simple déviance et désigne la pratique de la prostitution. Ce phénomène soulève la question de la présence des femmes dans l'espace public au Maroc, un endroit que l'on a trop souvent associé aux hommes dans les pays dits arabo-musulmans, reléguant les femmes dans le privé. Or, celles-ci évoluent dans l'espace public depuis bien longtemps et c'est justement leur agencement dans cet espace qui doit interpeller.

L-khrij («sortie») n'est pas considéré comme un travail. À propos de ses colocataires, Khadija marque la différence entre le fait de sortir et de travailler. Par ailleurs, même lorsque j'interrogeais des professionnelles sur leur travail, elles énuméraient les différents emplois qu'elles occupaient ou avaient occupés - service domestique, restauration, travail en usine de textile... - mais ne mentionnaient jamais la vente du sexe. À défaut de définir le service sexuel en termes de «travail», les femmes préfèrent parler de «débrouillardise». Au moment d'aborder la question des gains, elles emploient le terme arabe: tandabar, tan-dipani, ce qui signifie «je me débrouille». Ces mots sont également utilisés par des personnes qui ne sont pas impliquées dans ces activités et qui ne veulent pas stigmatiser celles qui les pratiquent. En effet, aucun jugement de valeur n'est porté sur ces femmes, qui sont, dès lors, considérées comme des victimes de leurs conditions sociales et de la démission de l'État face aux problèmes de carence scolaire, de chômage et d'absence d'insertion professionnelle. Ainsi, de tan-khrej à tan dabar on passe de la stigmatisation à la victimisation ou, au contraire, à la reconnaissance d'une autonomisation si ces termes sont utilisés par les protagonistes.

\section{Conclusion}

Même si ces différentes pratiques sont considérées comme déviantes, parce que stigmatisées par la société, par ceux et celles qui les adoptent, elles favorisent l'émergence de modes de constructions individuels et - dans les cas de la colocation où une jeunesse s'active pour elle-même - de fabrication des identités féminines qui décompressent 
les statuts traditionnels. Grâce à l'expérience de la colocation et de la vie pour soi, on apprend "avec d'autres» extérieurs au cadre familial. L'accès aux espaces extrafamiliaux permet aux subjectivités de se manifester différemment. Bien évidemment, la colocation des femmes est encore mal acceptée sur le plan social, contrairement à celle des hommes. Cette pratique est suspecte même si elle est justifiée par des raisons professionnelles - pour aider sa famille ou s'assurer un avenir en étudiant. Dès lors qu'on partage un appartement, on ne fait plus partie des «bnat diourhoum», c'est-à-dire des filles de maison vertueuses. On a "bougé» et, partant, les identités sexuelles se transforment. Cette jeunesse fait l'expérience de nouvelles manières de vivre la ville, celle de la sexualité urbaine entre autres.

\section{Références bibliographiques}

Dialmy, A. 2005. Société civile et laïcisation du droit familial et sexuel au Maroc, http://www.cids.auf.org/jour3/dialmy.rtf

Direction de la statistique. 2005. Enquête nationale sur les niveaux de vie des ménages 1998/1999, premiers résultats publiés in Rapport de synthèse de l'enquête nationale sur les valeurs, (Rap.) $\mathrm{H}$. Rachik. In 50 ans de développement humain et perspective 2025, http://www.rdh50.ma/fr/gt02.asp

Tabet, P. 2004. La Grande arnaque. Sexualité des femmes et échange économico-sexuel. Paris: L'Harmattan.

Vidal, C. 1977. Guerre des sexes à Abidjan. Masculin, féminin, CFA. Cahiers d'Études Africaines. XVII (65) : I24-I25. 



\title{
Transactions autour des corps et insertion en Suisse. Des Camerounaises qui « se débrouillent » à Lausanne
}

\author{
Joëlle Schwarz*
}

\section{Introduction}

Du fait de la pluralité de formes, de modalités et de temporalités des migrations, il est difficile de définir celles-ci précisément. Ce travail traite des stratégies migratoires mises en place par des femmes dans un mouvement Sud-Nord. Plus précisément, le contexte est celui de Camerounaises qui quittent leur pays, leur famille, leurs enfants pour «tenter leur chance» en Europe, là où d'autres avant elles ont «réussi». Certaines viennent en Suisse pour chercher du travail et un revenu qui servira à améliorer le niveau de vie de leur famille restée au pays. D'autres fuient des contraintes familiales ou sociales. Quelles que soient leurs motivations de départ et la façon dont elles ont franchi les frontières, elles se retrouvent confrontées à la nécessité de s'insérer en Suisse, une réalité qu'elles semblent avoir peu anticipée. Comme nous le verrons, l'éventail des possibilités qui s'offrent à une

* Social development specialist, Institut tropical et de santé publique suisse, joelle.schwarz@unibas.ch

Schwarz, P. 2012. Transactions autour des corps et insertion en Suisse. Des Camerounaises qui «se débrouillent» à Lausanne. In Chic, chèque, choc. Transactions autour des corps et stratégies amoureuses contemporaines. 107-119. Actes des colloques genre et développement. Berne: DDC-Commission suisse pour l'UNESCO; Genève: IHEID. 
femme africaine peu ou dé-qualifiée en situation de séjour irrégulière est restreint. Une partie d'entre elles réussissent à s'intégrer au moyen de transactions autour des corps que les Camerounais qualifient de «débrouilles»'.

\section{Présentation de la recherche}

Cet article s'appuie sur une recherche menée en automne 2006 dans le cadre d'un mémoire de DEA ${ }^{2}$ à l'Institut universitaire d'études du développement ${ }^{3}$. Ce travail de terrain portait sur les trajectoires migratoires de femmes camerounaises vers la Suisse et s'est intéressé à la façon dont celles-ci se «débrouillent» dans la société helvétique, ces stratégies d'insertion comprenant notamment une période de prostitution.

\section{Méthodologie}

Lors de cette recherche, trois entretiens qualitatifs approfondis ont été conduits qui ont permis de reconstruire les histoires de vie de ces femmes, c'est-à-dire les récits qui relatent non seulement l'épisode migratoire en tant que tel, mais également son contexte préalable (préparation, attentes du départ) et l'arrivée de la personne en Suisse. Cette recherche repose sur un nombre restreint d'entretiens et la prétention n'est pas de dépeindre la réalité de l'ensemble des Camerounaises qui se «débrouillent» en Suisse. Ce groupe n'est d'ailleurs pas représentatif de la population féminine originaire de ce pays. Malgré tout, ce travail a fonction d'illustration (Bertaux 1997). En effet, les récits de Nina, d'Éliane et de Marie présentent trois trajectoires migratoires possibles dans un contexte donné. Si ces informatrices ont suivi le même parcours géographique, les raisons qui les ont conduites à s'expatrier diffèrent, tout comme les discours qu'elles tiennent sur leur situation. Toutefois, toutes trois ont développé des stratégies qui font intervenir des transactions autour de leur corps.

1 Dans le jargon camerounais du milieu, «se débrouiller» signifie exercer une activité qui n'est pas forcément honorable et licite, mais qui permet de s'en sortir. L'une de mes informatrices explique que ce terme désigne avant tout la prostitution pour les femmes et le banditisme pour les hommes. Voir aussi Lado $(2005,24)$.

2 Diplôme d'études approfondies.

3 L'Institut universitaire d'études du développement est devenu l'Institut de hautes études internationales et du développement (IHEID) en 2008. 
Certains thèmes communs aux trois trajectoires ont ainsi pu être dégagés et ont été approfondis avec l'appui de la littérature existante.

\section{Définitions et précisions}

Ces «transactions autour des corps» peuvent être analysées à travers le prisme de l'échange économico-sexuel tel que le décrit Paola Tabet. Ce concept permet d'inscrire la prostitution et, dans certains cas, le mariage dans une acception plus large des relations sexuelles entre homme et femme impliquant une transaction économique. Tabet explique que «de la part des femmes, il y a fourniture d'un service ou prestation, variable en nature et en durée, mais comprenant l'usage sexuel; de la part des hommes, il y a remise d'une compensation ou rétribution d'importance et de nature variables, mais de toute façon liée à la possibilité d'usage sexuel de la femme, à son accessibilité sexuelle» (1987, 2-3). Selon l'auteure toujours, cet échange économicosexuel est intrinsèquement lié à la division internationale du travail:

La différence d'accès à la propriété en faveur des hommes, et ce au-delà des différences de classe, ainsi que (là où existe le travail salarié, dans les sociétés industrialisées ou en voie de développement) les salaires inégaux et l'inégal accès au travail, en particulier à des emplois plus qualifiés et mieux rémunérés, constituent autant d'éléments matériels bien connus qui continuent à forger la dépendance des femmes aux hommes, y compris sur le plan individuel, et, partant, à instituer l'échange économico-sexuel comme forme générale de rapport entre les sexes» $(2004,8)$.

Nous verrons que nos informatrices ont eu recours à plusieurs formes d'échange économico-sexuel pour assurer leur insertion en Suisse, notamment aux rapports sexuels tarifés et au mariage.

\section{Contexte de la migration et de l'insertion en Suisse}

\section{Migration des femmes camerounaises vers l'Europe}

Avant de présenter les récits de vie des trois informatrices de ce travail, il convient d'exposer plus généralement le contexte dans lequel s'opère la migration. Les flux migratoires sont fréquemment présentés en termes de facteurs pull et push. Les indicateurs push décrivent les 
raisons qui poussent les personnes à quitter leur pays ou région d'origine, les pull ceux qui attirent les migrants et les incitent à s'expatrier. Bien que cette approche néoclassique tende à appréhender avant tout les motivations économiques dans la migration, nous l'élargissons aux motivations également sociales et symboliques des migrants, qui comprennent notamment l'attraction de l'Europe, fondée sur le mythe de l'Eldorado, et la place économique traditionnelle des femmes dans la société camerounaise.

Selon Ludovic Lado, anthropologue camerounais, l'Occident est considéré comme un Eldorado des temps modernes, la terre de toutes les chances, des diplômes, de l'emploi formel et de l'argent (2005). Ce mythe est perpétué par les personnes qui émigrent car, une fois qu'elle sont arrivées à destination, elles envoient régulièrement de l'argent afin de répondre aux règles de la solidarité familiale, voire communautaire, et de maintenir leur statut dans une perspective de retour. Les migrants sont ainsi porteurs d'une image de «réussite». Ce récit originel est également alimenté par les émissions de télévision diffusées par l'Occident. Le désir de quitter une situation qui n'offre aucune perspective et qui est, de surcroît, aux antipodes de l'imaginaire véhiculé par les médias et par les récits des émigrés est un facteur explicatif important de la migration Sud-Nord.

Si l'on considère maintenant la place des femmes dans la sphère économique, on observe que la plupart d'entre elles se concentrent dans le secteur informel. Les choix éducatifs et professionnels sont marqués par le genre et, de façon générale, les femmes occupent une position minoritaire dans l'économie formelle, perçue comme typiquement masculine (Ferme 200I, 193). Dans certains contextes, cette division sexuelle du travail peut avoir des conséquences favorables pour les femmes, notamment lors des périodes de récession économique puisque, du fait de leur expérience et de leurs compétences dans le secteur informel, elles $y$ ont acquis une situation de quasi-monopole. Dès lors, elles sont plus à même de répondre aux crises. Cette faculté à se "débrouiller» et à trouver des revenus est aussi un avantage lors de la migration, particulièrement lorsque celle-ci a lieu sans permis de séjour et que l'insertion s'effectue par le biais de l'économie informelle. Relevons encore que la migration des Camerounaises a été facilitée par l'abrogation, en 1990, de la loi qui imposait la signature du mari sur la demande de visa d'émigration des femmes. 


\section{Contexte migratoire et insertion en Suisse}

La Suisse se trouvant dans une position géographiquement centrale en Europe, sa politique migratoire est très proche de celle des pays voisins. Comme eux, elle tend à restreindre les mouvements des personnes non désirables ou considérées comme économiquement non rentables. Depuis quelques années, la Suisse adopte une logique sécuritaire et cherche à contrôler les flux migratoires et les dangers qu'ils représentent (Caloz-Tschopp 1995). À moins qu'ils ne soient hautement qualifiés et que leur travail représente explicitement une plus value pour l'économie, les migrants économiques ne sont pas les bienvenus sur le sol helvétique.

\section{Présentation des récits de vie}

Les trois informatrices ont des trajectoires migratoires différentes, bien que leurs lieux de départ et d'arrivée soient les mêmes. Voici résumés, en quelques lignes, leur profil et leur histoire.

$\mathrm{Nina}^{4}$ a 28 ans. Elle a grandi à Yaoundé. Elle est l'aînée d'une famille aisée et étendue, son père étant polygame. Elle a étudié à l'Université de Yaoundé où elle a obtenu une licence universitaire en français moderne. En 200I, elle quitte le Cameroun afin d'échapper au harcèlement de la deuxième femme de son père. Elle rejoint une amie à Paris qui ne peut l'héberger. Nina partage alors le logement d'un Camerounais rencontré dans l'avion qui la conduisait à Paris. Durant plusieurs mois, elle vit dans cet appartement qui accueille de plus en plus de monde. Une fois ses réserves financières épuisées, elle s'adresse à son amie qui lui donne de l'argent. Cette dernière lui explique par la suite qu'elle gagne sa vie en exerçant la prostitution. À court d'alternatives et de perspectives, Nina choisit de la suivre dans cette voie et se prostitue à son tour, pendant deux ans à Paris puis à Lausanne. Au cours de cette période, Nina envoie parfois jusqu'à 3000 euros par mois au Cameroun ainsi que des cadeaux pour sa mère, son père et même sa belle-mère qui était pourtant la cause principale de son départ. À Lausanne, elle travaille dans un puff ${ }^{5}$ dont le loyer s'élève à 500 CHF par semaine. Elle se rend dans différentes villes de Suisse, en

4 Tous les noms d'informatrices empruntés dans ce texte sont fictifs.

5 Un puff est terme allemand qui désigne les maisons closes. 
fonction des manifestations. Sa famille s'habitue à ces envois d'argent, et désormais, lorsqu'un événement social a lieu (baptême, mariage, etc.), ses parents lui demandent de le financer. Son mariage en 2004 avec l'un de ses clients lui permet de sortir de la prostitution et d'obtenir un permis de séjour et donc de travail. Mais son époux ne veut pas la laisser trouver un emploi et devient son proxénète. La rencontre de Nina a lieu dans un foyer pour femmes victimes de violences conjugales où elle entreprend des démarches pour se séparer de son conjoint et pour trouver un emploi ainsi qu'un appartement. Elle cumule les postes précaires et le peu d'argent qu'elle gagne ne lui permet pas d'envoyer les mêmes montants qu'auparavant au Cameroun. Sa famille interprète cette diminution comme une marque d'égoïsme et d'abandon de sa part, ce qui représente un réel problème pour Nina puisqu'elle perd son «statut» dans son pays d'origine et voit ainsi son espoir de retour s'amenuiser. Cependant, elle ne peut absolument pas avouer à ses parents la source de ses revenus précédents.

Éliane, 39 ans, vient également de Yaoundé. Elle a quatre enfants et ne s'est jamais mariée. Au Cameroun, elle jongle entre travail formel au ministère et petit commerce informel. Elle décide de venir en Suisse car elle a entendu dire que la vie y est facile et elle a des ambitions commerciales. En 2003, elle donne $5000 \mathrm{CHF}$ à un passeur et rejoint son cousin à Bâle, marié à une Suissesse. Elle y reste quelques semaines. Lorsque son cousin lui explique comment les Camerounaises qu'il connaît "se débrouillent», elle refuse cette pratique et opte pour la voie de l'asile. Elle «se renseigne» et décide de construire son dossier en misant sur la persécution individuelle, inventant une histoire de toutes pièces. Pendant la procédure, elle rencontre son mari, un Suisse plus âgé qu'elle, avec lequel elle s'installe à Lausanne. Elle annule alors sa demande d'asile et effectue des petits boulots pour pouvoir envoyer de l'argent à sa mère qui s'occupe de ses enfants. L'un d'entre eux est malade et les trois autres sont en internat. Son époux l'accuse de se prostituer et l'expulse de l'appartement en 2006. Actuellement, elle loge dans une petite pension et cherche un travail. Bien qu'Éliane ait accepté cet entretien et qu'elle connaisse le sujet de cette recherche, elle refuse de parler de prostitution pendant l'entretien, arguant qu'elle a toujours réussi à se débrouiller autrement.

Marie a 50 ans. Née à Yaoundé, elle s'est mariée et est allée vivre à la campagne dans la famille de son mari. Le ménage, alors composé 
de trois enfants, du couple et des beaux-parents, vit des revenus du père menuisier et des ventes des produits maraîchers cultivés par Marie. En 1999, à la suite du décès de son mari, elle accompagne en Suisse sa sœur qui rejoint son futur époux rencontré sur Internet. Une fois arrivée, elle décide de rester car elle estime qu'elle sera ainsi plus à même de subvenir aux besoins de sa famille. Elle explique qu'au début, des hommes l'arrêtent dans la rue et lui demandent quel est son tarif pour une passe. Ces requêtes commencent par la surprendre mais l'idée fait son chemin et devient concevable. Cette activité lui permet d'obtenir de l'argent facilement, explique-t-elle. Elle se prostitue dans plusieurs villes de Suisse, dans des puffs. Elle rencontre son mari en 2002 et quitte le monde de la prostitution. Actuellement, elle fait des ménages et travaille en parallèle pour une association de soutien aux prostituées à Lausanne où elle assure une permanence la nuit. Elle envoie régulièrement de l'argent, mais surtout des paquets (vêtements, matériel scolaire, etc.) à sa belle-mère qui s'occupe des enfants et des cultures maraîchères. Ses deux filles jumelles sont encore mineures, mais son petit salaire ne lui permet pas de les faire venir, «ça n'irait pas», estime-t-elle. De surcroît, son mari bénéficie de l'Assurance invalidité et est alcoolique. Elle explique qu'elle reste en Suisse par «devoir conjugal».

\section{Contextualisation des voies d'insertion}

Comme exposé précédemment, l'insertion en Suisse diffère suivant la provenance et les qualifications de la personne. Dans le cas de femmes camerounaises, les possibilités d'insertion sont plutôt minces et se résument principalement au travail informel (la prostitution), à l'asile et au mariage, celui-ci donnant accès au travail formel. Ces trois voies comprennent des transactions autour des corps et, peuvent, l'asile mis à part, être appréhendées à travers le prisme de l'échange économicosexuel.

\section{Le travail}

L'insertion légale en Suisse, par le travail, ne peut se faire qu'à certaines conditions. Tout d'abord, la demande de permis de séjour et de travail doit être adressée par l'employeur aux services de migration avant que la personne n'entre sur le territoire suisse. De surcroît, l'attribution des 
permis B ou $L$ est limitée par des quotas alloués aux cantons et ceux-ci sont réservés en priorité aux personnes provenant de l'espace européen, qualifiées et travaillant à plein temps. Bien que Nina ait une licence universitaire, lorsqu'elle arrive en France puis en Suisse, elle n'essaie pas de faire reconnaître son diplôme, pas plus que son conseiller à l'office régional de placement qui ne lui propose que des emplois dans le domaine des services. Cette situation est synonyme, pour elle, de déqualification. Puisque les trois informatrices n'ont pas de permis de séjour valables, ne viennent pas d'une région privilégiée et n'ont pas de hautes qualifications scolaires, Nina mise à part, leurs chances d'obtenir un permis de travail sont quasiment nulles. Aucune d'entre elles ne tente d'ailleurs d'emprunter cette voie.

Du fait de leur statut de sans-papiers, Nina, Éliane et Marie sont confinées au secteur informel. En Suisse, ces emplois sont généralement répartis en fonction des nationalités. Comme le relève le sociologue Marcello Valli dans une étude sur le travail illégal à Lausanne (2003), les immigrés peuvent schématiquement être regroupés par nationalité et par type de travail effectué. Cet auteur observe qu'une majorité de femmes sud-américaines sont actives dans la sphère domestique et des soins, que les femmes camerounaises et brésiliennes se concentrent davantage dans la prostitution de rue alors que les Asiatiques sont nombreuses dans le domaine de la restauration. Par ailleurs, le travail informel est fréquemment synonyme de précarité étant donné qu'il se caractérise par son absence de droits et de protection. Éliane a cherché des heures de ménage, mais sans succès. Nina explique ne pas avoir trouvé d'autres solutions que la prostitution. Quant à Marie, elle s'est vite aperçue que cette activité était le meilleur moyen de gagner de l'argent «facilement».

La prostitution est d'autant plus facilement envisagée qu'elle est accessible. En effet, il existe un réseau en Suisse, créé à la fois pour et par des Camerounaises. Les puffs sont gérés par des Camerounaises plus âgées qui hébergent avant tout des compatriotes. Ce réseau est étendu puisque les femmes se déplacent de puff en puff suivant les foires, les tournois de football ou les forums. A Lausanne, il existe un quartier délimité où les femmes de ce pays exercent la prostitution et un bar où elles peuvent être rencontrées. Cette activité permet aux informatrices d'obtenir des sommes d'argent assez importantes qu'elles envoient au Cameroun. Cependant, cette situation les main- 
tient dans l'irrégularité et la menace d'être arrêtée et renvoyée est permanente. Dans le cas de Nina et de Marie, la mise à profit du corps est à la fois un moyen de survie et une façon de réussir en Europe. L'échange économico-sexuel est envisagé comme une solution provisoire mais néanmoins avantageuse puisqu'elle permet de répondre aux besoins de la famille. Marie envoie de l'argent à ses beaux-parents et ses enfants. Quant à Nina, elle aide sa mère, délaissée par son père polygame au profit d'une nouvelle épouse.

\section{L'asile}

De manière générale, la voie de l'asile est difficile à emprunter pour les Camerounais car leur pays est considéré comme sûr par l'Office fédéral des migrations. Les persécutions individuelles ne sont pas acceptées comme motif d'asile, à moins que le renvoi du requérant n'occasionne une détresse personnelle grave, auquel cas celui-ci peut bénéficier d'une admission provisoire. Éliane a cependant privilégié cette voie à celle de la prostitution. Au cours de la seconde entrevue avec Éliane, celle-ci explique comment elle a élaboré sa stratégie. Lors des entretiens menés dans le cadre de l'enquête pour la demande d'asile, elle racontait une histoire inventée de toutes pièces. Son récit prenait la forme d'une mise en scène de son corps puisqu'elle expliquait avoir été mariée de force à un homme âgé avec lequel elle était contrainte d'avoir des relations sexuelles. Un jour, il décède des suites d'un empoisonnement. Elle est accusée et mise en prison où elle doit exécuter des travaux forcés. Alors qu'elle travaille dans un champ, un gardien la sépare du groupe et la viole. Elle parvient à s'évader et trouve un passeur qui la conduit en Suisse où elle dépose une demande d'asile. Éliane a ainsi construit son dossier autour de son intégrité physique et de sa santé mentale

\section{Le mariage}

Le mariage permet à un immigré sans permis de séjour de s'insérer légalement et durablement en Suisse. Les portes du travail formel lui sont alors ouvertes. Cette recherche a montré que si l'alliance n'a pas été la première option choisie par Nina, Éliane et Marie, elle s'est vite imposée comme la solution pour une insertion stable et durable. Notons par ailleurs que les interfaces permettant aux hommes occidentaux et aux femmes du Sud de se rencontrer sont nombreuses: 
sites Internet, journaux, listes de téléphones et/ou courriers sont des moyens pour le mail order bride ou contract bride ${ }^{6}$. Un site camerounais consulté comprend de nombreux témoignages de femmes qui ont quitté leur pays pour rejoindre leur "chéri blanc» et qui ont été désillusionnées lors de leur arrivée en Europe (en Suisse fréquemment). Certaines se sont retrouvées dans un réseau de prostitution. La plupart d'entre elles écrivent pour sensibiliser les éventuelles candidates à ce type d'émigration ${ }^{7}$.

Les trois informatrices se sont mariées à des Suisses ou à une personne disposant d'un permis de séjour, dans le cas de Nina. Éliane et Marie décrivent le mariage comme un échange de bons procédés où elles endossent le rôle d'épouses aimantes. Les mots d'Éliane sont éloquents à cet égard:

Quand je visitais là, je me disais toujours que si je peux trouver un homme qui peut me prendre comme épouse, vraiment cet homme sera l'homme le plus heureux de sa vie, parce que moi je ne veux pas l'embêter pour lui dire «ah, moi je vais (...)» pour aller faire la pute, c'est pas dans mes habitudes.

Aux yeux de Marie, la vie passée de son mari divorcé ne l'intéresse pas. Elle présente leur union comme celle de deux personnes qui ont besoin l'une de l'autre, à un moment donné, pour différentes raisons et qui s'entraident. Bien qu'elle dise clairement que son mariage est un arrangement satisfaisant les deux parties, elle n'imagine pas pour autant rompre cette alliance pour rentrer auprès de sa famille. Éliane et Marie jouent leur rôle d'épouse et toutes deux justifient de la même façon le fait de ne pas faire venir leurs enfants en Suisse: «Cela n'irait pas», estiment-elles. Éliane ne veut pas que ses enfants la voient dans sa situation. En effet, son mari vient de l'expulser de l'appartement. Marie explique que son mari et elle habitent dans un studio qui est trop exigu. Quant à Nina, elle s'est mariée à un de ses clients. Elle se méfiait cependant de lui et exigea qu'ils vivent ensemble durant six mois avant qu'elle n'accepte de s'unir à lui. Elle craignait que leur rela-

6 II est intéressant de constater que le site africain www.afrik.com est automatiquement redirigé sur le site suisse www.swissfriends.ch.

7 www.cameroon-info.net 
tion ne soit faussée par le contexte de leur rencontre. Peu après leur mariage, lorsqu'elle a voulu chercher du travail, son mari a refusé et lui a demandé de reprendre ses activités de prostitution. C'est à ce moment que les violences conjugales ont commencé. Nina s'était déjà rendue auparavant dans un foyer pour femmes victimes de violences conjugales. Mais après avoir été avertie que son permis de séjour exigeait qu'elle «vive auprès du conjoint», faute de quoi elle risquait de devoir quitter le pays, elle était retournée vivre auprès de lui.

\section{Le retour}

En cas d'échec des autres stratégies d'insertion, les immigrés ont toujours la possibilité de retourner au pays. Pour nos informatrices, cette solution n'en est pas une car cette démarche est signe d'échec et provoquerait leur désaffiliation sociale:

Nina: Et puis, retourner au Cameroun, quand tu n'as pas de papiers, que tu n'as encore rien, c'est synonyme de défaite. C'està-dire qu'on va tellement se moquer de toi, que tu peux te... Des gens qu'on rapatrie au Cameroun, ils vont se cacher.

Dans le cas de Marie et d'Éliane, le retour n'est pas seulement synonyme de défaite, mais il est tout simplement impossible à cause du manque de perspectives économiques et professionnelles au Cameroun. Le revenu des ventes maraîchères de Marie est insuffisant pour faire vivre sa famille. Quant à Éliane, la situation économique actuelle ne lui permettrait plus de faire du commerce comme avant. Ainsi, bien qu'elles évoquent avec tristesse et nostalgie les temps passés dans leur pays d'origine, toutes deux choisissent de rester en Suisse car c'est là qu'elles sont le plus utiles à leur famille. Pour Nina, il n'est pas question de rentrer avant d'avoir fait construire une maison.

\section{Conclusion}

Cette recherche a été focalisée sur les trajectoires de migration de femmes camerounaises et sur la façon dont elles se sont «débrouillées» pour s'insérer en Suisse. Leur désenchantement est grand car la réussite recherchée est difficile à atteindre. L'intégration de ces trois femmes a ainsi nécessité l'intervention de transactions 
autour des corps qui, comme les migrations, prennent des formes, des modalités, des temporalités, des sens et des niveaux d'analyse différents. Ces transactions dans leur diversité s'échelonnent sur le continuum des échanges économico-sexuels. Les récits de vie permettent d'illustrer trois types de compromis où le corps est troqué contre un service. Nina et Marie échangent leur corps contre de l'argent qui leur permet de vivre et dont elles envoient une partie au Cameroun. Le corps est ici objet sexuel. Éliane met en scène le sien pour obtenir un permis de réfugiée. L'organisme devient, dès lors, objet d'abus. Finalement, toutes trois jouent le rôle d'épouse contre une régularisation de leur statut. C'est la dimension du corps objet domestique qui intervient ici. Or, ce statut d'épouse est limité au contexte suisse et n'inclut pas celui de mère, puisque ni Éliane ni Marie ne font venir leurs enfants du Cameroun.

De manière générale, le ou la migrant-e doit «se débrouiller» s'il veut réussir, ce succès s'incarnant dans l'envoi ponctuel d'argent ou de biens à la famille au pays. Cette transmission financière a deux fonctions interdépendantes. La première est d'ordre économique car cet argent permet d'améliorer son niveau de vie. Mais sa vertu est aussi sociale. En effet, leurs parents voient leur prestige et leur reconnaissance augmenter grâce à ces envois. Par conséquent, l'échec a une double incidence sur la famille du ou de la migrant-e qui met en œuvre tous les moyens de «débrouille» pour assurer sa réussite.

Pour terminer, rappelons que les possibilités pour une immigrée sans permis de séjour et de travail en Suisse de gagner un revenu sont peu nombreuses. La politique migratoire qui ne cesse de se durcir restreint encore sa marge de manœuvre. L'Eldorado européen n'en reste pourtant pas moins attractif. Les femmes camerounaises qui réussissent à migrer mettent en place des stratégies de «débrouille». Toutes sont bonnes à penser puisque, comme l'explique Nina, mieux vaut se trouver dans la misère à l'étranger et faire croire à une réussite que se retrouver dans le dénuement au pays et montrer que l'on a échoué.

\section{Références bibliographiques}

Bertaux, D. 1996. Les récits de vie. Paris: Nathan Université.

Caloz-Tschopp, M. C. 1995. La Suisse, terre de refoulement(s). In Le pouvoir suisse.

(Dir.) F. Masnata et C. Rubattel. 4I4-427.Vevey: L'Aire Historique. 
Ferme, M. C. 200I. A social biography of gender in Cameroonian society and politics. African Studies Review. 44(2): 187-194.

Lado, L. 2005. L'imagination africaine de l'Occident. Études. 4031 : 2.

Tabet, P. 1987. Du don au tarif. Les relations sexuelles impliquant une compensation. Les Temps modernes. $\mathrm{N}^{\circ} 490$.

—. 2004. La grande arnaque. Sexualité des femmes et échange économico-sexuel. Paris: L'Harmattan.

Valli, M. 2003. Les migrants sans permis de séjour à Lausanne. Rapport rédigé à la demande de la Municipalité de Lausanne, Lausanne. 



\title{
Love, money and construction of masculinity among young people in Dessie town
}

\author{
Getnet Tadele*
}

If I walk with my head down like a stranger in the town I know so well in broad daylight... it is because of you! If I lose the meaning of life and hate my creation as a human... it is because of you! If my life has become a race in a dark cave and I myself have become only better than the dead to be below all the living... it is because of you! If I have turned my eye away from all the life that is around so as to see more clearly the field of love that I have sown over the hillsides/mountains faraway in my imagination... it is all because of you! I taught you the very alphabets of love holding your hands and pointing them at each of them "L... O...V... E". But in return, you taught me the whole sentence of hatred and betrayal with all its bitterness! My heart won't stop loving you whether you like it or not/ whether you care a damn. I tried so hard to win your love for it was the only wealth I sought to have, and what other sort of wealth did I have? None! As you know. But what more would mint of money do for me if I had your love, for indeed if I had your love, I would consider myself the richest per-

Sociologist, Addis Ababa University, gtadele@sosa.aau.edu.et

Tadele, G. 20 I2. Love, money and construction of masculinity among young people in Dessie town. In Chic, chèque, choc. Transactions autour des corps et stratégies amoureuses contemporaines. $12 \mathrm{I}-152$. Actes des colloques genre et développement. Berne: DDC-Commission suisse pour l'UNESCO; Genève: IHEID. 
son in the world. But all this has come to nothing. You denied me all that I strived to gather and it all ended in dismay/despair. But why now? Why does it have to be now? Was this the time for it? You know Sewnet, sometimes I wonder about this. What drew you so near me then, what deficit, what need brought you so near? And what abundance, what luxury takes you away now? What did you see in me then to have come so close, and what did you discover in me that sent you away in a fright. Or was it a virtue that you saw in another and not a fault in me that took you away?... Yigzaw is just the son of one unfortunate civil servant who looks to the government for a livelihood and is not a rich guy. And if it wasn't for this unfortunate "luck", he knows quite well what he would have done. But yet he knows how to love even if he couldn't be loved so well in return (have I said wrong?). But whom could he love to be loved in return? Maybe he should find someone "miserably poor" like himself, desperate to be loved and to return it and not to someone as rich as you are. But what you need to know here is that poverty is not a divine curse sent from the very hands of God. I am like the rest of humanity, created with two hands and can work with them and make a fortune like... And riches isn't the bridge that joins people in love as you seem to think. Though you have turned it the wrong way, care gives love all the wealth that money cannot and though I do not pretend to know better than you, I say you have it all the more by the wrong end of the stick. Please hold still that wandering heart of yours for just a moment, stop that selfish thinking in your mind and listen to me... What is love? For me love is thoughtfulness, care, and kindness... And in love is found clarity and trust, simplicity and sincerity. But sometimes I think that when love wants to be "modern" (zemnay), it becomes helplessly addicted to money and turns into an ugly monster of a creation. Why do the "modern" equate love with gain?

As for me, I think God has given me not only the burden of your love but also strength to carry it. And if my love is "primitive" it can't keep pace with its "modern" counterpart. But the "modern" put their hearts in their pockets together with their money and until I can learn to be one such fellow, I shall content myself in a self-exile that takes me away from you. But I think I shall return 
one day as my exile is for a partner in life, and because living without such a partner would be like clapping with one hand, I shall return for that partner one day! Sewnet I know not the day, but one day when I have become man enough I will return. That is if death doesn't overtake me in my race to become human. Then I will come straight to you even before going to my family and I beg you to receive me with outstretched arms. I feel such sorrow for not having found you any better. You hated me when you could have loved me, and when you could have drawn nearer. You fled further away. For this I feel sorrow, but could I hate you? How can I... My heart, though it cries from the bitter pain you inflicted on me, cannot find courage enough to hate you. And my prayer is this... may it please God to let us meet again when I am a "man" and you are more kindly disposed. And even if I cease to exist and turn to dust, I will continue to love you! I promise. He who loves you sincerely (signed) Yigzaw (3 Oct. 200I at 3a.m.)

(Love) letters like the one above serve as one means for young lovers to share feelings, discuss conflict, or clarify the causes of break-up. Yigzaw and Sewnet used to attend the same school. He said that one day there was a musical show in an open ground in their school. While enjoying the musical show, he suddenly saw Sewnet - "black girl with beautiful eyes" - sitting with her face almost covered with her clothes to give herself some shade from the sun. Their eyes met as he was staring at her and he had to turn away and cast his eyes down. She soon slipped from his memory and his attention turned to the music on the stage. But their eyes met again when he turned towards her, which startled him. He says he did not know what had overcome him as he followed her to her class after the show was over. He saw that she was in Section D, and he was then in Section $\mathrm{H}$. They were not very far apart. And after school, he followed her all the way to her home and only went back to his brother's home after he had seen her enter into her compound. He said that he was besotted by her, even without speaking to her, and it took him more than a year to get in touch with her with the help of schoolteachers and friends. He strongly desired to possess her, and worked hard towards that goal with the support of teachers and friends. Finally he made it. Their relationship lasted for about eight months, and the letter was written after they broke up. 
The letter is redolent with the excitement, sweetness, and strength of romantic love, along with the pain, anger, suffering, bitterness, and sadness that occurs when there is a breach with the beloved. Yigzaw was desperately expressing a desire to be wanted, liked, and needed, as well as his agony of passionate love. He struggled to figure out what he had done wrong or what had gone wrong and attempted to find answers for himself. It appears that things had fallen apart after he had made an enormous emotional investment. In the depths of despair, he had even attempted to commit suicide by drinking poison and had been hospitalised for several days. During my stay in the field, Yigzaw was depressed most of the time and there were times when he was overcome with irritation, walking the streets like one possessed.

A number of interpretive challenges present themselves when we try to dissect the letter, but the central theme appears to revolve around the relationship between money and love. Competing rhetoric of modernity, love, and money intersect in the letter. Yigzaw stressed that he would win Sewnet back when he had become a "man" that is, once he is earning money and has become rich. Masculinity or manhood is defined in terms of the possession of wealth. Yigzaw strongly believed that his girlfriend, who was from an affluent family, had rejected him for being poor. He used the term "modern" a couple of times as a metaphor for the morally loose (Western) and moneyminded (consumerist). His letter suggests the need to look at how the ideas and experiences of love, romance, and sexuality are embedded in an increase in consumerism.

The main questions addressed in this chapter are: How do young people understand and express love and relationships in their daily lives? How do they construct masculinity and femininity in the context of scarcity of love and money? More specifically, how do young people initiate relationships and what is the role of money in a relationship?

The chapter draws from small-scale surveys, interviews, focus group discussions and observations held with young men and women (school pupils and street children) in Dessie, a provincial town in Ethiopia. Fieldwork was conducted in three phases: the first phase took place from October 200I to July 2002; and the second phase fieldwork was carried out from November 2002 to March 2003. The data collected during these two phases served a $\mathrm{PhD}$ research that 
mainly focused on young people's (schools pupils and street youths) perception of sex, love, marriage, HIVIAIDS in the context of poverty and ongoing HIVIAIDS intervention programmes. In a third phase, additional data was also collected in February and March 2005 (after completing my PhD dissertation). I also draw from data that I collected in 2006-7 from men who have sex with men in Addis Ababa.

\section{Setting the scene: sexuality and youth in Dessie}

\section{Dessie}

The establishment of a strong central government and a national capital towards the end of the $19^{\text {th }}$ century gave rise to a number of towns that served as regional capitals. Dessie is such a town with a long history and great historical significance. According to different sources, the town of Dessie was founded in 1886 by Ras Mikael (Ras literally meaning 'head', or the highest traditional title below that of King) (Ali 1997). Once Dessie had been chosen to be the seat for Ras Mikael (latter Negus or King Mikael), it also rapidly became the centre for all sorts of economic (commercial) and social undertakings in the region. Thanks to its strategic location, Dessie was a transit point for merchants who traded goods from the northern regions of Eritrea, Tigray, and Afar to the central highlands, including the capital. Hence, many past regimes have used the town of Dessie as an administrative capital for the then Province of Wollo. Until the 1974 revolution, the town served as a seat for the crown prince and governors who were assigned by the emperors to administer the region. Between 1974 and 199I, it served as the administrative capital of what was Wollo Province (kifle-hager) and also housed the regional headquarters of the then ruling party. Since 1991, although diminished in scope, it continues to serve as the administrative capital for the South Wollo Administrative Zone and currently houses a number of civil, non-governmental, religious and administrative offices (Municipality of Dessie 2000).

\section{The predicament of Dessian youth}

For young people, the situation in Wollo is quite difficult and even critical, as droughts and famine afflict this area more often than any other part of Ethiopia. 
The region of Wollo may have the world record in recent famines. There were widespread famines in this region in the years 196667, 1972-73 and 1984-85. The last two were brought to world attention through the TV reports made, respectively, by Jonathan Dimbleby and Mohamed Amin/Michael Buerk. The first was hardly known outside the area. But with or without the knowledge of the world, the Wollo people have gone through this traumatic disaster three times in less than one generation. It would be difficult to find any region in the world that has been so devastated by famines in the last generation. Until any other evidence disproves it, Wollo can claim a world record in famines. (Hareide I99I, I40; see also Ali 1997)

Poverty is a severe problem in Dessie, as evidenced by the congestion, the deteriorating roads and sanitation services, and an ever-growing number of street children and adults. Although statistics are not available, key informants estimated that the unemployment rate in Dessie is higher than the national average. There were no universities, colleges or other higher training institutions at the time of this study. As a result, many young people had little or no access to vocational training and educational opportunities. There was an acute shortage of public recreational services such as sporting facilities, parks, cinemas, theatres, and public libraries. The only cinema/theatre in the town (the Wollo Cultural Centre), for example, was crumbling down from a lack of maintenance. This has contributed to the flourishing of illegal video houses throughout the town (see Tadele 2006 for a discussion on pornographic films). The sporting facilities were no better. The only football stadium in the town seems to have been abandoned before its construction even really took shape. There were no properly built fields that could host other forms of sporting activities such as handball, basketball, lawn tennis, and volleyball. There was only one single public library that can only answer to the needs of about 200 readers. To escape from this unpleasant reality, most young people find solace in the various vicarious and exciting activities within their reach, such as chewing chat, drinking alcohol, smoking, and sexual activities.

For many young people, street activities such as begging, petty theft, prostitution, and involvement in other deviant and criminal activities have increasingly become the only alternatives for survival or just 
part of their daily routine. Dessie is said to be a safe place, but group rape, and more generally sexual harassment and violence is a constant fear among schoolgirls, street girls, and prostitutes (Tadele 2006). It seems that lack of opportunities encumbered by hopelessness, and an inability to fulfil customary economic roles and obligations to win the hearts of women have led young men to commit group rape and other sexual violence to boost their masculinity and self-esteem (Silberschmidt 200I).

\section{Sexuality in Dessie}

The availability of information about sexual issues depends largely on how free people are to talk about sex (Campenhoudt et al. 1997). In most parts of Ethiopia, the culture demands that men, and women in particular, suppress their sexual desires, and not wear miniskirts, or other provocative clothes that expose their bodies. As a whole, talking about sexual issues openly is not approved of, and is considered shameful or even sinful. Many ways are resorted to in order to minimize sexual desires. Besides serving cultural and hygienic purposes, female circumcision, for example, is partly practised to suppress women's sexuality. All these measures imply that sexual desire and pleasure are portrayed as something to be avoided, and it is possible to classify much of Ethiopia as a prudish society (at the risk of making a judgmental statement). In highland Ethiopian culture, the absence of traditional systems (like that of ssengas in Uganda) that teach young people (both boys and girls) about sexuality and techniques to experience sexual pleasure partly substantiates my argument (see Kinsman et al. 2000 for a discussion on the role of ssengas in Uganda).

The situation in Wollo appears to be different, and the place is hailed as a haven for love and romance. Wolde-Mariam (1991, 19) argues:

Love reigns in Wello. Most Ethiopian monarchs understood this fact. Some examples from recent times include [Emperor] Tewodros, who was married to a Welloye but failed to capitalize on it; [Emperor] Yohannis, who legitimized the appointment of his son as the governor of Wello by having him marry a Welloye; [Emperor] Minilik after him, who also married a Welloye, as did [Emperor] Haile Sillase, perhaps the last monarch. 
Broadly speaking, in public discourse, Welloyes are known for their relative openness in talking about sexuality. There is also a musical tradition that praises the place and the beauties it harbours in songs. Most of the cultural and romantic songs in Ethiopia emanate from Wollo and are composed of words that express, explicitly or implicitly, feelings of love fostered by members of the opposite sexes for one another. My choice of Dessie as a research site, therefore, was influenced by the presumed openness and willingness of people to talk about sexuality.

This description is intended to place love and sexuality in a wider context in order to develop a proper perspective for appreciating the external dimension of the issues involved, while hopefully providing the background necessary for understanding the situation in which young people express their love and sexuality in the different empirical sections that follow.

\section{Love, relationships, and money among school pupils}

If the boy is of a poor family and doesn't dress well, he should not expect to have a girlfriend. Such a thought does not enter his mind much because he has little chance of attracting girls even if he does want to get one (Keder, I8-year-old male).

It is an inevitable fact that most young men and women in all societies are attracted to each other, fall in love, feel sexual desire, and end up in a marriage or a break-up. This is why many poets, novelists, and storytellers throughout the ages have devoted their time to narrating the intensity of excitement that arises when people fall in love, and the anger and frustration generated when they break up. Therefore, love and relationships unfold over time in almost all societies, and in the process people also exchange different things to initiate or maintain a relationship. The quotation above was spontaneously expressed by one of the informants in Dessie in response to a question "What do girls take into account in order to say 'yes' to a relationship?". Almost all the young men, women and even the key informants were convinced that the first thing girls consider in response to a proposed relationship is money. They argued that people (particularly women) usually marry for money and not for love. The questions asked are "What does he own?" and "What does she own?" and not "Do I love him?" 
or "Do I love her?". Some informants went even further and commented that love is a thing of the past. Sendeku (22 years, male student) had this to say:

(...) In fact, I don't think there is any love these days. Some people also say that the word "LOVE" itself has been omitted from the dictionary. As the time itself is corrupt, a man approaches a woman just by splashing his money about and a woman approaches a man only when she believes that he has money. Those who are drawn together by true love are very few. A man makes a woman agree with him only by the power of his money or by force/intimidation, but not because of love. As I told you earlier, it is money that plays the biggest role. It is the backbone in a man-woman relationship. If a man has enough money, he can have sex with as many women as he desires. Especially now, a rich man can buy as many ladies as he fancies just like chattels. It is becoming a common practice for girls these days to look for a man with money and trap him. It is the amount of money a person has that is paid due regard. They find out whose son he is, and if he has money then they hunt him down and grab him. The culture has been corrupted over time.

It appears that it is not only women who approach men with money, men also approach women by throwing their wealth around. Such behaviour implies that both partners are aware of the existence of an exchange transaction. It was argued that money is the sole motivation that binds women to men (implying that men could be sexually undesirable). To make a long story short, love is perceived as a commodity and women are seen as objects that a man with money can buy. It is also believed that a man in possession of wealth should adopt a macho personality or "hegemonic masculinity" (Connell 1995). The narrative reflects on commodified sexuality and sexualised commodities in the sense that to be a lover is to be able to spend money on the beloved, and to be loved is to be overwhelmed with gifts and other tokens of love. Love is constructed as a commodity and offering love enables women to acquire and consume commodities. The informant spewed out his discontent not only about developments in sexual culture but also by commenting that the entire "culture has been corrupted". This 
is a reflection of dominant public discourse that everything is going in the wrong direction. Romanticizing the past golden age seems to be part and parcel of public discourse in most societies. There are plenty of issues that people usually view with positive nostalgia.

One of the most common contemporary slang expressions in Ethiopia is "There is no love these days". This informant went so far as to say that the word love has now been omitted from the dictionary. When we extend his argument, it means that love has disappeared from the face of the earth or perhaps just from Ethiopia or from Dessie, and a word for something that no longer exists should be expunged from the dictionary. Accordingly, the publishers or the authors of dictionaries have decided to omit the word love from the latest editions. The discourse that "There is no love these days" touches mainly on romantic love, but also touches on the dearth of love for humanity that people seem to display for one another. It is a frenzied, negative, and moralising discourse which expresses the common belief that the drastic socio-economic transformations have been brought about by consumerism, urbanisation, globalisation, war, and famine, which have given rise to individualistic thinking and initiated the transformation of the entire fabric of traditional Ethiopian culture.

The role of money in relationships was emphasised time and again: the comment that, "There is no love these days" was pronounced more elaborately by Muhe ( 18 years, male student) as follows:

There isn't any love in the first place. It would have been very nice if there were real love, but unfortunately I haven't seen one such example of this so far. It is just love of money that is mistaken for love, and lust too. Girls do not love those who love them; they love those who have money. Many lovers hold their love not in their hearts but in their lips. It is just "I love you, I love you", then it is forgotten after they separate, and, if the girl finds a better person [in terms of wealth], she won't hesitate to go with him straightaway.

The young people in Dessie drew a picture in which the only thing women were interested in was money (see also Moyer 2003 for similar discourse in Tanzania). Women were presented to be manipulative 
- commodifying their bodies; some of the informants placed the blame fairly and squarely on girls/women, and tried to portray men as true lovers. Here is what Shigute (20 years, male student) said:

The woman/girl will not approach any man out of true love. Be sure it is a done deal, no one! What you may find is a lady who asks: "What is he? What does he own? In what business is he engaged?" Men are better in this regard in Dessie. The men are true lovers. However, all the women care about is business.

Perhaps somewhat cynically, this informant perceived women as objects that can be fooled around with, and argued that a man may not necessarily be required to prove his financial status.

Since the women do not feel real love, if you just have some small thing to show off with, and if you back this up by boasting of the other things you have, you can go out with many beautiful women. Make no mistake, talk is enough for her. Just tell her that you have this or that. She doesn't even have to see you spending money. Just tell her that you have this or that and you will definitely have her. These are the types of women/girls that you will find in Dessie. To gain acceptance, one has to fulfil the criteria that are expected of a man. Not to beat about the bush, he has to have money. If he has, he can do whatever she wants him to do. A penniless man may beg a lady throughout his life, but he will never win her.

It appears that hegemonic constructions of both masculinity and femininity are displayed and acted out in a performing sense. The informant emphasised, sex-consumerism and seduction offered by rich men are the only way to gain the acceptance of women. Most of those involved in the study also noted that most relationships do not last for long as the motive is not love but money and sexual intercourse. To emphasise this, they said that they see a girl with one boy today and with another the next day, and they said they have not yet seen a relationship that has endured even a single year. That is why they think there is no love in Dessie. Pursuing their theme they said that since most relationships are started mainly for sexual pleasure and material benefits, it does not usu- 
ally take more than a week for sex to be initiated. After they have had enough of each other sexually, both start looking for another partner.

In such a climate, it is inevitable that the importance of money was emphasized not only for casual relationships, but also for marriage. They maintained that people usually marry for money and not for love. Even the key informants involved in the study echoed the above narrations. One young key informant (the chairman of the AntiAIDS Club) concluded that their (women's) motto has become: "Be with a person who has money (ke alew tetega)". The following story from one of the key informants is a good illustration of how even parents easily give consent to a wealthy person's proposal. The informant said that money is only needed in order to marry whomsoever one pleases, and the only factor that determines the outcome of a proposal is the wealth of the man who proposes.

This informant narrated the story of a certain young man who was not particularly rich but unfortunately fell in love with a daughter of a very wealthy merchant. He said that the poor young man was, fortunately, not so poor when it came to his wits and he devised an excellent strategy that would enable him to secure the girl of his dreams in a legal marriage once and for all. He took a load of merchandise belonging to a friend of his to the wealthy merchant's warehouse and asked if he would be able to store "his" merchandise there for a while, for which permission was granted. He then sent shimagles (men who propose marriage to the girl's family on behalf of the man) to the wealthy merchant and asked for his daughter's hand. When the wealthy merchant heard the name, he could not recall having heard it before and so he asked:"Who is this man?" The shimagles responded, "It is the man who stored all that merchandise in your warehouse the other day". The old man did not need any more persuasion to give his consent. Only later did he become aware of the ruse, after his daughter had been married and it was too late to remedy the situation.

This story reminds me of an Ethiopian novel (a very popular love story) by the Ethiopian novelist, the late Haddis Alemayehu (1968) FiQir Iske MeQabir (literally, "Love unto the grave"). The novel depicts human relationships in feudal Ethiopia, and is a bold criticism of the system. The central characters in the novel are a young girl, the daughter of an upper class family who claim to be balabat (local notables; descendants of a distinguished family), and a poor young man who is 
recruited to tutor her. Eventually the two fall in love, but a marriage between these two people from different social backgrounds was unthinkable, as the girl's parents would not consent to their request. Her father in particular was incapable of understanding her love that transcended social class barriers and wanted to find and punish her lover. Undeterred, the couple was deeply in love, and decided to elope and live together in Addis Ababa. The young man was the first to leave and the girl followed him later without knowing the whereabouts of her lover. Death overcame them both while they were still searching for one another, but eventually they were buried in the same grave, hence the title of the novel. This story from Dessie demonstrates that the rich businessman was not willing to give his daughter away because her suitor was not from the same class (businessman with plenty of merchandise). Indeed, in the Ethiopia of the past (and even in rural Ethiopia today), marriage was more of an economic and social contract between the parents involved, lending the story above an element of truth.

It would be easy enough to assume that the males are pointing their fingers at females for commodifying sex, love, and marriage, and I had fully expected that the young women would repudiate such accusations. On the contrary, even young women from different schools admitted that most relationships do not involve love. Like the young men, the young women also upheld the belief in the power money and gifts exercise over women. They noted that a girl may accept a boy out of consideration for his material status, contemplating the material gain the relationship may provide her. Boys on their part, the girls claimed, resort to all sorts of ploys in order to increase their chances of being accepted. To this end, Sinke (I 8 years, female) said:

A boy will present himself to a girl in whom he is interested as being the best of all his kind and try to convince her he would take care of her better than any other boy would. He will also claim to be in possession of great material wealth. "I am the son of a rich family, and we own a grain mill and other assets in the countryside". Boys will also claim to be very popular and generally liked. Even clothing is a weapon. They borrow good clothes from their friends and when the girl sees another person wearing those same clothes, they claim to have given them to him as a present. 
Girls usually say "OK" if the boy happens to dress fashionably, that is if he wears real big shoes, baggy trousers, or real sunglasses and things like that (cool things).

This story reveals that dressing well is an indication of prosperity and sophistication or a true expression of masculinity in Ethiopia, where many young people cannot afford new clothes. These things, which are taken for granted in the West, are much sought after in Ethiopia. The image of big shoes, baggy trousers, and sunglasses is partly a hangover from exposure to Western films' (Black American rappers), television programmes, and magazines. It appears that material goods, love, desire, and sexiness are intermingled, and masculinity/manhood is expressed in dress, speech, and caring behaviour. Indubitably, the display of conspicuous consumption is seen as sexy and alluring and in order, to have sex and love, it is essential to consume. Money generates the power, authority, and ability for consumption and sexiness. The story also casts light on the fact that young men can count on their parents' wealth in their pursuit of the hearts of women. The girls said that all men/boys are boastful (guregna) and assure girls that they are there to deal with all their problems and difficulties. Pertinently, the girls pointed out that a real lover would appear honest and full of humility instead of boasting about his imagined wealth, but unfortunately, girls rarely accept such boys for a relationship. This phenomenon - the absence of humble men approaching women, and the materialistic tendency of women and their parents - was elaborated on by another high school girl, Sada ( 17 years):

When it's all said and done, men hate to humble themselves in their approaches to women. They would rather come over as arrogant and talk big about themselves. They fabricate false stories just to attract women. Only a few men speak the truth about themselves. On the other hand, women are not keenly interested in true love. Most of them opt for money. They are easily attracted by material stuff. Let me tell you a true story. There was

Pornographic and other types of Western low-budget movies can be seen in a number of underground pornographic houses in Dessie, and young people frequently visit such places (Tadele 2006). 
a girl in my neighbourhood. A man living in Addis Ababa was in love with her. He came from Addis and settled in Dessie just to lure the girl into his hands. What he did was borrow a car and money from his friends in Addis and come to Dessie. In Dessie he rented a villa with the money he had borrowed. He also cruised around Dessie in his car. He did all these things to be accepted by the family of the girl he loved as a rich man. It so happened that the family of the girl was deceived by the pretence of the man and believed he was rich. They gave him their daughter. Mind you, he won the girl through cheating. He was not really rich. After a while, he told the girl that he is not a rich person that the villa he rented did not belong to him, but that he had rented it with the money he had borrowed from his friends. He confessed to his girl that he did all these things because he loved her and wanted to win her heart. The girl accepted his reason. Her family was also finally convinced. His real job in Addis Ababa was that of a broker (delala). This case shows that women and their parents in Dessie are easily attracted by money and fame.

This anecdote reminds me of a popular joke in Addis Ababa, namely, in order to find a beautiful wife, it is necessary to have three Vs: villa, video-player, and a vehicle. Video-players used to be very expensive during the Marxist regime because the centralised economic policy placed high taxes on them. Even these days, it is not easy for any public servant to have all three Vs. Particularly, having a villa or even decent accommodation and a vehicle is beyond the means of most young people. The story above implies that the man came with a borrowed vehicle and started living in a rented villa claiming that they were his own personal property. This indicated that he had addressed two Vs, and people took the presence of a video-player in a villa for granted. The story again shows a notion of love and its link with consumption: catching a potential lover's attention by displaying commodities, even if borrowed. Cogently, the story also reveals how parents are easily seduced into giving their daughters to rich men. It is true that many families in Ethiopia (even in urban areas) usually meddle in the marriages of their daughters and sons. Many families prefer a man who offers gifts (tilosh), and can provide their daughter with security and comfort. Though arranged marriages are becoming rare in urban areas, 
parents, relatives, friends, and colleagues are usually involved in mate selection to some extent. At times, when the parents do not allow their daughter to marry the man she loves, she runs away from home and ends up in prostitution.

The role of money even features during sexual intercourse. Yigzaw attributed his inability to make love to a virgin girl (Sewnet) to poverty.

Every time she groaned "Eh" in some pain I sprang to my feet for fear that I would hurt her. I always said, "There would be time enough for everything". But whenever she screamed in some pain, I always broke off the sex and many were the times that I had to ejaculate outside. But I think she had her own plans too and I now think she never wanted to give her virginity to me, maybe because I was poor or maybe she knew she wouldn't be with me forever.

When asked about the conditions that lead to the break down of a relationship, the schoolboys argued "No one will love you if you do not have money; at least no girl will love you". They maintained that if someone has convinced a girl to have a relationship with the help of some cash, and if he experiences some misfortune in between that leaves him short of money, the woman will not waste any time in leaving him. Let me give an illustrative example:

For example, if I had had a girl friend when I was attending primary and junior high schools in my village and we both came to high school here in Dessie, she would see that there were plenty of fashionable things that I could not offer, and she would look for someone who would offer her all these (Adane 19 years, male student).

It appeared that the young men considered all relationships to be basically consumerist in nature and overwhelmingly portrayed their idea that relationships are based on a constant stream of material gains, and a break in the transaction of material benefits leads to automatic termination of the relationship. In this way, women are perceived to be invariably rational. 
In the questionnaire, response to the question "What makes a girl say 'Yes' to the relationship to the point of having sex?" yielded more or less similar results. The options given in the questionnaire were many (financial situation, love, physical beauty, peer pressure, intimidation, good manners, fame, and popularity) and they were asked to mark only the two most important ones. Thus, 25 percent of respondents opted for money and fame, 20 percent for money and intimidation, 15 percent for money and peer pressure, 15 percent for love and good manners, 10 percent for money and love, 10 percent for money and physical beauty, and 5 percent for money and good manners. This is a categorical indication that money or socio-economic position appear to be the dominant and motivating factor in luring young girls into a relationship to the point of having sex. Going one step further, in addition to money, the quantitative results revealed that most of the girls seek popularity and like to appear trailing behind famous persons, apparently because they lack self-confidence, crushed by the inferior position to which society relegates them. A good athlete, for example, would be widely known in such a close-knit neighbourhood as Dessie, and women associating themselves with him would be respected. The other possible explanation is that by associating themselves with famous men, girls guard themselves from being bothered by other young men who seek a relationship.

In conclusion, what prevailed in the discussion with informants totally excludes the existence of love and romanticism in Dessie; both love and money are perceived as scarce. Interestingly enough, my study with men who have sex with men (MSM) in Addis Ababa revealed the same findings. One of the issues that emerged from this study is that almost all informants I interviewed expressed their dissatisfaction with their sexuality. Some of the reasons are obvious: stigma, particularly self or internalised stigma, discrimination, expectations from the family and society, etc. Besides these, the MSM involved in the study expressed that they are not happy with their sexuality because they couldn't find intimacy in the gay world. They said that casual encounters remain an important part of the total experience in the gay world. Almost all informants argued that most relationships are fleeting and often dependent on transaction of resources. They portrayed that gays in Addis Ababa are after lust or money with no desire to have intimate relationship. They went further and argued that homosexuality implies 
having a lot of different partners. Again and again they claimed that it is not the rule to confirm a loving relationship by social or material commitments and MSM have less propensity to establish a lasting relationship with one partner. They further added that having a special relationship with one man does not mean refusing all other relationships. The partnership remains "open" although the two may live together. This has contributed to their unhappiness in life (Tadele 2008).

I argue that such an economic approach to love, relationships, and marriage should be taken with a pinch of salt. It is my impression that there are people who fall in love regardless of other extrinsic benefits. It also appears very difficult to detect clear-cut demarcations, whether the attachment is founded on financial benefits or emotional involvement or love. By and large, the economic approach contradicts the lofty ideals of love and relationships in many societies (poor or rich), and I would argue that not all relationships depend on the rational comparison of costs and benefits. Sociologically speaking, socialisation or environment to a large extent influences the personality traits of individuals, but then it is not possible to claim that all individuals within a given community like Dessie are the same and behave in the same way. In other words, sex, relationships, and marriage can be matters of transaction to some people but not to all members of the sexually active population in Dessie. The informants' explanations seem to deny individual differences, as each woman can be unique in a certain sense.

The argument also contradicts the works of Ethiopian artists, poets, and novelists who have been attempting to highlight the intensity of the excitement generated when people fall in love. It appears that cast down by the high rate of unemployment and subsequent hopelessness, young people have reached a state of emotion whereby everything seems to have been robbed of its original meaning; an impression shaped by their fears and desires. Such a dreary outlook reflects personal emotions, aspirations, tensions, and uncertainties that young people are grappling with in their daily lives. They also seem to have been influenced by a public discourse that states everything has lost its original meaning (a nostalgic and stubborn conviction that all things are now going in the wrong direction). Senior members of the society have become harbingers of doom in all aspects of life and prefer talking about the demise of the "golden culture" of past days. 
So far an attempt has been made to highlight the interrelationship between love, relationships, and money. Now the question is how do young people initiate a relationship?

\section{"Fighting the war": negotiating love among school pupils}

Even when I initiate acquaintanceships, I do not just go and chat up a girl. I first make friends with someone close to her. Then I will talk with that person and get him/her to invite her somewhere some time where I will show up as if by accident. He/she will then introduce me to her and I will join them. The third party will then remember some urgent business he/she had quite forgotten to deal with and will soon be gone leaving us there to make the best of the time. Sometimes, he/she will come back after a while, sometimes not. But either way I will say whatever I want to (ye meqedewn eqedalehu) and try to impress the girl. I would usually get their phone numbers and phone them at a later day. You know they prefer the phone as it puts them at ease and makes them feel relaxed, especially the Muslim girls. I think this is because other people do not witness the phone call. Anyway, I will make my call and things start moving. I have yet to see a girl who has said no to me consistently and refused to yield (Dagne 20 years, male).

This story reveals how most young people negotiate relationships. The story implies that initiating a relationship involves people other than the couple. Thus, of all the different ways of initiating a relationship, mediation by a peer or peers appeared to be the most common. Friends are the main bridges that bring boys and girls together in a relationship. The schoolboys argued that if a boy wants to start a relationship with a girl, he first becomes friends with one of her female friends, but once he is introduced to the girl on whom he has set his sights, he forgets about the one he made acquaintance with first and focuses on the target girl. More specifically, they remarked that there are "pimps" among the girl students. They are known as awagi (someone who gets the "war" going). Ashagre (22 years, male) asserted: 
If you want to date a girl, you go and tell an awagi that you want to date a certain girl. She will make sure that you have the girl by fair means or foul (be balem be bolem bla). She will ask her to go to the cafeteria during the tea break at school. Then, she will introduce the guy saying that he is from a wealthy family, and the girl thus targeted will give in very soon, and even consent to sex. After arranging the battle, the awagi will disappear. After you get what you want from the girl you dated, she (the mediator) asks you questions like, "How was it?" and "What did you do?". I think the awagiwoch (plural for awagi) achieve vicarious satisfaction from listening to your response.

Likewise, the female informants argued that it is not often the girl who decides for herself, but that her girlfriends will usually do the job for her. They noted that it sometimes happens that a girl might even accept a boy for whom she does not have any feelings, yielding to peer pressure (gudegna wosewosa/wotewota). When a girl becomes involved with a boyfriend, she then serves as a mediator between one of her boyfriend's friends and her own closest friend (girl) and fixes them up so that she will not be having the experience alone. They added that gifts from boyfriends also play a very important role, not only in inducing the girl recipient to commit herself to a relationship (including sex), but also in encouraging her friends to look for a similar boyfriend who would likewise give them gifts. In a nutshell, most of them agreed that peer pressure (ye guadegna wosewosa) plays a key role in accepting or rejecting a boy.

The lengthy story of Yigzaw's relationship with Sewnet reveals that intermediaries, including teachers and friends, became involved to enable him to speak and draw closer to her. The whole story is strewn with friends and relatives who either tried to help him secure the girl or who plotted to separate them. This is partly a reflection of the culture of mate selection, which involves many people (families, friends, colleagues). It appears that it is very difficult for many young men to express their love or feelings in words to the girls of their own accord, even after establishing closer relationships. Most of them either have to use mediators or express their feelings over the phone. It was argued that the phone was the most suitable medium for both girls and boys to discuss romance or dating and it circumvented the inevitable tension of expressing feelings face to face. This partly 
explains why issues related to sex and sexuality in Ethiopia are secret, and most young people do not dare to talk about them openly. It is a country where sex is not widely discussed in the family nor is it addressed in the formal education system.

Interestingly enough, sex is perceived as a form of war, and the mediator is viewed as the mastermind behind the war. When informants were asked about local idioms and metaphors referring to sex, some of them noted that sex is referred to as Badme (one of the war fronts in the latest war between Ethiopia and Eritrea, where a fierce battle was fought). When asked why is it called Badme, they responded that just as a war takes place between two opposite groups, sexual intercourse is also a battle between opposite sexes. Although Ethiopia has other good things to show the world, its image is associated with war and famine, and in this context the war metaphor seems well chosen by the young people. This metaphor seems to apply not only to sexual intercourse: life as a whole is a daily battle for survival for many young people, and hence "The sexual story is a personal narrative that is socially embedded in the daily practices and strategies of everyday life" (Plummer 1995, 15). It also implies that addressing sex bluntly and using the word sex are taboo. Hence young people employ various metaphors and veiled terms to describe it.

The young men were then asked what a man should do or how he should present himself to convince a woman to accept him. Some maintained that the boy should seek her out very frequently and have a chat, but such natter should not be "dry". He should also invite her to some cafeterias and entertain her as best he can within his means. He should also be skilled in how to talk to women (afe linorew yigebal, enden ayenetu kerfafa kehone gene waga yelewom). Others noted that one should joke because girls like boys who can make them laugh. Dagim, a 19-year-old male, remarked that if he likes a girl, he does not need instructions on how to approach her:

By any means I can, I will try my best to grab her (ekelatefalehu... be bolem be balem beye ekelatefatalehu). It is said that white (ferengi) girls have a hundred and one reasons when they say "No" to sex, but our girls here have only got three and I know them well. The first is "My mother will not allow me to do such a thing" (enate tekotagnalech); the second is "I already have a boyfriend"; and the 
third is "I have a goal in my life and doing this will only stand in my way" (alama alegne). And as to how these can be got around, you tell her that her mother has also gone through what she is now doing (when she tells you her mother won't allow it), and if she tells you that she has a boyfriend, you ask her to introduce him to you, and she will be afraid to do that even if she has, thinking that you two will have a fight. As to the "goal" stuff, you convince her that you will not demand sex and will not stand in her way to her goal. Once you convince her, sex will follow if you want it to.

The informant presented himself as smart and well versed in the skill of convincing girls, an adept at masculine behaviour. It appeared that the custom in Ethiopia (perhaps elsewhere as well) does not allow women to consent immediately when men propose, even if they want to, as they could be perceived as "cheap" or as a "prostitute". The young men appeared to be familiar with refusal at the first attempt and accepted it as part of the courting ritual (they emphasized that a refusal from a girl is no different from a yes; when girls say no it is like music, and it is tantamount to saying yes). It is perceived as innate female behaviour and adds flavour to the negotiation process. Some young men confessed that that they do not want a girl who initiates a relationship or is easy to "conquer". Teka (20 years, male) had this to say:

You know when a girl asks you or tells you she is in love with you, well you will publicize it and preen yourself in front of your friends, but you won't feel terribly pleased about going out with her. I don't know if this stems from our culture but you just don't feel so pleased about dating her or feel as good as the way you feel when you ask a girl yourself and convince her to go out with you. You feel as if you are inferior if you accept a girl who asks you to date her.

These young informants have grown up in a society where men are supposed to initiate relationships and should go to great lengths to convince women. The inevitable upshot is that women resist men's advances and play innocent and hard to get, and males also believe that a man should not shirk setting out to woo the girl of his dreams. It appears that this sort of negotiation lends excitement and romantic opportuni- 
ties, and is perceived of as part and parcel of the courting ritual or flirting by both women and men. Besides being part of the courting ritual, women may use this strategy for pragmatic reasons, for instance, to evaluate whether the person could be a potential life-long partner.

\section{'Being Listro, No girlfriend': Love and relationships among male street youths}

The tales of the school pupils about love and money are echoed by the stories of male street youths. But unlike the students involved in this study, street youths did not report having same-age girlfriends with whom they could nurture a romantic relationship, and had to resort to buying sex from prostitutes. Desperate boys hungry for sex go to women equally desperate for cash. The reasons given for not having girlfriends were related to the young men's low self-esteem and their abject social status. The street youths argued that the girls of their age, when accepting or rejecting a relationship with a boy, considered his socio-economic status and his family background. It is only until they have ascertained such things that they may not consent, but once these facts have been verified to their satisfaction they tend to acquiesce. They noted that it is not only women but also the general public that treat them as inferiors just because they polish shoes. Almost all of street youths felt that the general public has adopted a negative attitude towards them.

Some people look down on us as if we are beneath the soles of their shoes. Such people consider us of less value than the shoes we clean and I hate being a listro (Agonafir, 20 years, street male).

The view that having a girlfriend requires looking good, dressing smartly, and having some cash in the pockets was adamantly expressed by the participants. When asked what people like them, people who do not meet these requirements would do if they wanted girlfriends, they replied that no girl would be willing to be a girlfriend of a listro. If they wanted girls, their only choice was to go to a far away neighbourhood and convince girls there to have sex with them in the twinkling of an eye, before their backgrounds might inadvertently be revealed by some misfortune. Bekele (19-year-old shoe-shine boy) expressed it like this: 
I would like to approach some girls but when they hear that I clean shoes in the Piazza, they consider me as if I were less than a man and treat me as an inferior.

He did admit that there might be some girls for whom being a listro may not matter and that he is waiting for such a girl to come his way, but added that many girls even avoid him because of what they have heard about him already by hearsay. He said that no girl would be willing to start a relationship with a listro knowingly. The only way to achieve anything was to assume a more pleasant persona and approach a distant girl who will not be likely to know about his background. He reported that he would rather buy sex from a prostitute than go through all this fuss and bother.

Even if you convince one girl by telling her things that you are not, the time will come when she sees you cleaning shoes and that is the end of you. Therefore, it is better to buy sex.

Wudu (22-year-old shoe-shine boy) said that he became acquainted with a girl attending high school. One day they met and spent some time in a private room together but without having sexual intercourse. They agreed to meet another time and to have sex. Another day, she was passing by the Piazza (the place where he worked), and when she turned around he happened to turn around too, and they saw each other. At that time the girl made the sign of the cross (to express her shock and disbelief), and went away saying "Oh God!" Then he reported that he was ashamed, and broke off his relationship with her. He commented that such incidents happened to many of his shoe-shine friends.

My friends have suffered many incidents like this. Most of them broke up after having good relations. I know three guys who broke up relationships after having spent many times together. They even had intercourse with the girls. But after the girls realised that they were shoe-shine boys they went away. Sometimes the girls happened to see the guys at work and they went away after that. Very recently, I started a relationship with another girl. I told her everything, except what I do for a living. We had sex once. We are now still in love. Her friends know me 
now (that I am a shoe-shine boy). They have good relationship with me and they haven't told her that I work as a shoe-shine boy.

A few street youths ventured to contest such an assertion. Here is an excerpt from an interview with Bedru (20-year-old shoe-shine boy):

This is their own view; this kind of thing has never happened before. We could in fact be despised by the society. But shoeshining is not a type of work to be underestimated and you have to start from something simple to chase after real achievement. You have to be open when talking with a girl and not one has rejected me for the sole reason that I'm a shoe-shine boy. [Are there those who accepted you knowing that you are a shoe-shine boy?] I should ask a girl who is as poor as I am. I have to consider my social background and capacity and I should not go beyond the set boundaries by asking out a girl from a well-to-do family. We both have to be from the same social status. [Does a poor girl accept you knowing that you are a shoe-shine boy?] There is no problem with that; I haven't (however) come across with any such a case (rejection).

His response could be partly true and partly self-defence, preferring not to admit any inferiority. The fact remains that girls could reject such young men's proposals not only because the latter are poor with a low-paying job, but also because they are considered hoodlums by the general public. They reported that since most of street children smoke or chew chat or because their clothes are dirty, people think of them as hoodlums (durie) and thieves, and even the drivers will not allow them to work with them if they see them smoke and chew chat. Building their case, they argued that the common people - the passengers who come to the bus station (menaheria) to board buses - do not even consider them as human beings and treat them with contempt and call them names: "You robbers; thieves; vagabonds". "It seems that they [street youths] lack economic and political capital to be sure, but they also lack the moral and social capital one might possess as members of respectable households" (Moyer 2003:68). 
It became clear that even the street girls consider street boys to be ne'er-do-wells, and prefer assistants to drivers and other men who can give them more money than street youths. At this juncture I should also say that the complaint constantly voiced by street youths is a reflection of a widespread discourse about money, love, and relationships in Ethiopian society. The other explanation is that street youths rate themselves low and are afraid that women will not accept them. Given their socio-economic status, they may fear that women may despise them and turn down their proposal for a relationship.

Given their lack of exposure to romantic relationships, street youths' discourse was limited to negotiating sexual encounters with prostitutes rather than courting girls. Their narratives tend to revolve around how much they pay for a bed, a prostitute and other ways of buying sex. They noted that they pay on average 8 Birr (approximately I US dollar) for short-term intercourse and I5 Birr (about 2 US dollar) for overnight. They also noted that they maintain steady relationships with prostitutes while allowing them to make money from other customers.

If I come to a girl and if another person also happens to arrive, I will leave so that she will go with him. This is because I can meet her tomorrow or the next day. In addition, it is good if she gets money (Wudu, 22 years, male street youth).

Others even reported that they pimp for their steady prostitutes, and get free or discounted access for themselves. They also reported engaging in what they call "group sex" (Tadele, 2006).

Taken together, it appears that the street youths are not only deprived of basic civil services (education, employment, and healthcare), but also of love. The street youths like many other young people are blessed with a goodly dose of energy, and curiosity about and interest in love and being loved, but poverty implacably forbids this in their lives. Early in their lives, they are engaged in shoe-shining and other back-breaking jobs to support themselves and in some case their families. Since they lack love and a sense of accomplishment, they are far more likely to end up in a series of purely physical sexual encounters in an effort to compensate for the lack of love and warmth in their lives, and to affirm their own self-worth. Distress encumbered 
by a stressful life situation and lack of affection pushes them into activities like smoking, drugs, and rape or "group sex". Lacking in love and money, they also seem to be the farthest removed from the hegemonic masculinities which they cannot even hope to emulate, and they therefore have resorted to the use of violence to get sex (Tadele 2006). Most of the informants admitted that they use chat, alcohol, and smoke cigarettes. In short, their day-to-day lives were characterized by a constant struggle to find money and to maintain a supply of food, chat, alcohol, and sex. The inexorable conclusion has to be that the street youth suffer both from extreme material and emotional deprivation caused by the prevailing poverty, and social exclusion.

\section{Conclusion}

The foregoing description reveals that romantic love, relationships, and mate choice in Desssie are perceived to be not free nor romantic, but rather rational and calculating. The participants seemed to think that most women were "bought" into a relationship. All their explanations of how women submit to a relationship revolve around money and other material benefits. Hence, girls are seduced by gifts and the entertainment that good money can buy.

Why so much interest in money? In contemporary Western society there is a widespread perception that love and financial motives are incompatible. Why have love and relationships not been accorded the proper place that they deserve in Dessie? Is money the sole motivation for starting a relationship? Are these women not like any other human beings who need love and affection, with or without other material benefits? To address these and other similar questions, we need to understand the role of socio-economic factors as well as the cultural context of sexuality in Ethiopian society.

To start with, by all standards, Ethiopia is one of the poorest countries in the world, with an average annual per capita income of about USD 100. It is a country recurrently afflicted by drought, famine, and war, with no social security system (Tadele 2006). Unemployment is at an all time high and the urban poor cannot afford even the basic amenities. This sort of situation compels us to not downplay the important role that money plays in the negotiation of sexual relationships, which is the familiar argument in most of the literature on 
Africa. "The 'transactional nature' of sexual encounters and relationships in Africa is virtually an article of faith in the social demography and social research on AIDS across the continent, an 'old saw' in which sexuality and marriage are seen as essentially commercial transactions" (Schoepf 1992, 355 in Setel 1999,14I; see also Nnko and Pool 1995; Ankomah 1999; Kinsman et al. 2000; Nyanzi et al. 2000;Van der Geest 200 I ; 2004 ; Gibson 2004 ;Van den Borne 2005).

It is undeniably true that, in self-defence, women may consider what a relationship or marriage will provide in terms of material benefits as men have monopolised most of the scarce resources in the country. Educational opportunities for women are limited, and this affects their ability to support themselves as adults. With most doors closed to them, taking a boyfriend or husband is one strategy for survival and many authors have depicted the practice of taking a male for financial reasons (Standing 1992; Schoepf 1994; Van der Geest 200I; Mill and Anarfi 2002; Price and Hawkins 2002). Consistent with those findings, there are women from impoverished families in Dessie who enter into a relationship calculating the material gain it provides. They are simply following an inexorable form of logic: that money or material benefits inescapably play a role in sexual relationships, and that the women involved could well be aware of the exchange transaction taking place ${ }^{2}$. I, however, argue that money is only one of many factors that bind them to men, and emotional involvement may exist. It should therefore be noted that even though money and other material benefits are exchanged, it is very difficult to conclude that all relationships are no more than purely commercial transactions devoid of love or emotional attachment. They rather consist of "complex constellations of economic dependence, love, physical attraction and the pressure of social norms" (Gysels et al. 2002).

Pertinently, the strong relationship between love, relationships, and money cannot be explained by poverty only, as there are women who earn perhaps more than their partners, but still expect some form of material exchange. In the Ethiopian context, even the most successful professional or business women who earn more than their partners expect the men to cover at least most of the expenses of a

2 I am not referring to prostitutes, who explicitly ask for money in return for their sexual services. 
date. For such women, offering luxurious gifts or taking them to expensive resorts and covering all expenses alone expresses love and commitment on the man's side and has a symbolic or cultural significance in a relationship. Such women are not desperate for money; they may not be aware of the existence of any exchange transaction, and love or a relationship constitutes an end by itself. Men also feel that it is a masculine obligation to assume such responsibilities, and they may even do it without being aware of the transaction. Economic exchange in this context seems to be part of wider cultural constructions and practices. Having accepted this, we must understand that a gnawing need for erotic love and affection is present among women, and I would argue that money is not the only motivation for all women to start a relationship or to have sexual intercourse. In other words, for some women, money acts as an extra spice in a relationship that they enjoy for its own sake; they would enter into the relationship anyway. Even though it is a means of survival for others, different levels of emotional attachment could still exist in both cases. When we are aware that not all is cut and dried, it appears very difficult to accept fully an economic explanation of love and relationships as it implies a view of women as self-centred, materialistic robots devoid or incapable of any emotional attachment.

Analysis that focuses too heavily on the connections between economics and sex while excluding the themes of desire, passion and, in White's terms, "comfort", run the risk of suggesting that only those with enough money can afford love and pleasure. In order to avoid this assumption, it is important to reclaim desire, passion, and love as important themes in understanding sexuality... (Moyer 2003, 257).

As early as the 1920s and among very simple Melanesians, Malinowski uncovered the existence of exchange for sexual favours. With insight, he contextualised this and argued that material exchange is not the only motive that binds women to men:

In the course of every love affair the man has to constantly give small presents to the woman. To the natives the need of one-sided payment is self-evident. This custom implies that sexual inter- 
course, even where there is attachment, is a service rendered by the female to the male. As such it has to be repaid in accordance with the rule of reciprocity or give-and-take, which pervades tribal life, so that every gift, every service and every favour must be paid by something of equivalent value... This rule is by no means logical or self-evident. Considering the great freedom of women and their equality with men in all matters, especially that of sex, considering also that the natives fully realize that women are as inclined to intercourse as men, one would expect the sexual relation to be regarded as an exchange of services in itself reciprocal. But custom, arbitrary and inconsequent here as elsewhere, decrees that it is a service from women to men, and men have to pay (Malinowski 1932, 269).

Although love or a relationship is something mutual for both men and women, the social construction of masculinity always portrays men as needing sex or a relationship. In a nutshell, since men are the ones who are perceived to "need" love, sex, and relationships or "the service", they are expected to pay for it in one form or another. Cogently, the emphasis on the power of money or coercion implies that there are particular constructions, performance, and practices of masculinity that seem somewhat hegemonic and to which both the young men and women try to ascribe.

I also posit that the informants' views about the strong relationship between love, relationships, and money is a reflection of the widespread public discourse about the difficulty in identifying "trustworthy" marital partners, as most women are only "after money" (acquisitive motive), and as most men are only "after sexual intercourse" (lust-driven motive). Bearing this in mind, the ideas and opinions expressed by the informants might be based on assumptions that are taken for granted. Overall, the interrelationship between love and money is not simple, transparent, and linear, as argued by the informants, but rather fluid and complex, requiring deeper contextualization. "... Sexuality is among the forms of behaviour most dependent upon contextualizing contingencies" (Simon 1996, II5).

Finally, the love letter which launched this chapter and the other narratives from school pupils reveal the existence of romantic love, but why they claimed "There is no love these days" is a question that 
begs an answer and requires further investigation, perhaps by using a historical perspective. It appears that many of those involved in the study were very young and in the stage of exploring sex but with little or no emotional attachment. Further, many of them (if not all) also seem to be young, restless and want to have fun before settling for a meaningful relationship.

Moreover, when the young boys talked about love and relationships, they seemed to be referring to sexual relationships as well. As a result, sex and love are intermingled at all levels in young peoples' discourse. In an era of globalisation, the ways in which Yigzaw and many other young people talked about love seemed very much influenced by and reminiscent of stereotypical popular and increasingly visible Hollywood representations of love centred on romance, intimacy, active sexuality, and an almost natural sense of belonging together that are in stark contrast with the actual structure of many relationships in Dessie and perhaps throughout Ethiopia. It appears that the problem with relationships is what the ambitious partners have in mind for the relationship, which is an idealistic image that floats in the air, Hollywood style. My informants seem to be influenced by the relationships made in Hollywood, replete with miracles and adventurous events. In the real world, one has to work hard and relentlessly to make his/her relationship Hollywood-like, because no film director is around to make the relationship work. In the real world, couples should take the responsibility of directing their own real life drama (Tadele 2008).

\section{References}

Ali, M. A. 1997. A history of Dase Town (I94I-199I). MA thesis, Department of History, Addis Ababa University.

Ankomah, A. 1999. Sex, love, money and AIDS: The dynamics of premarital sexual relationships in Ghana. Sexualities. 2 (3): 29l-308.

Campenhoudt, L.V., M. Cohen, G. Guizzardi and D. Hauser (Eds). 1997. Sexual interactions and HIV risk: New conceptual perspectives in European research. London: Taylor and Francis.

Connell, R.W. 1995. Masculinities. Berkeley: University of California Press.

Gibson, D. 2003. Rape, vulnerability and doubt: Issues for healing and care. Medische Antropologie. I ( I): 43-64.

Gysels, M. et al. 2002. Women who sell sex in a Ugandan trading town: Life histories, survival strategies and risk. Social Science and Medicine. 54 (2): I 79- 192. 
Hareide, D. 1991. Vulnerability to famine. Oslo:The Alternative Future Project.

Kinsman, J. et al. 2000. Socializing influences and the value of sex: The experience of adolescent schoolgirls in rural Masaka, Uganda. Culture, Health and Sexuality. 2(2): $|5|-\mid 66$.

Malinowski, B. 1932. The sexual life of savages in Northwestern Melanesia: an ethnographic account of courtship, marriage and family life among the natives of the Trobriand Islands. British New Guinea. London: Routledge and Kegan Paul.

Mill, J. E. and J. K. Anarfi. 2002. HIV risk environment for Ghanaian women: Challenges to prevention. Social Science and Medicine. 54 (3):325-337.

Moyer, E. 2003. In the shadow of the Sheraton: Imagining localities in global spaces in Dar es Salaam, Tanzania. PhD dissertation, University of Amsterdam.

Municipality of Dessie Town. 2000. Strategic Plan of Dessie Town (200I-2006). Unpublished Amharic report: Dessie.

Nnko, S.and R. Pool. 1995. School pupils and the discourse of sex in Magu District, Tanzania.TANESA Working paper no. 3.

Nyanzi, S. et al. 2000. The negotiation of sexual relationships among school pupils in south-western Uganda. AIDS Care. I3 (I): 83-98.

Price, N. and K. Hawkins. 2002. Researching sexual and reproductive behaviour: A peer ethnographic approach. Social Science and Medicine. 55 (8): I 325-I 336.

Schoepf, B. G. 1995. Culture, sex research and AIDS prevention in Africa. In Culture and sexual risk: Anthropological perspectives on AIDS. (Eds.) H. Brummelhuis and G. Herdt. 29-5I.Amsterdam: Gordon and Breach.

Setel, P.W. 1999. A plague of paradoxes: AIDS, culture and demography in Northern Tanzania. Chicago: University of Chicago Press.

Silberschmidt, M. 200I. Disempowerment of men in rural and urban East Africa: Implications for male identity and sexual behaviour. World Development. 29 (4): 657-67I.

- 2004. Masculinities, sexuality and socio-economic change in rural and urban East Africa. In Re-thinking sexualities in Africa. (Ed.) S. Arnfred. 233-248. Sweden: Almqvist and Wiksell Tryckeri AB.

Standing, H. 1992. AIDS: Conceptual and methodological issues in researching sexual behavior in sub-Saharan Africa. Social Science and Medicine. 34(5): 475-483.

Tadele, G. 2006. Bleak Prospects: Young men, sexuality and HIVIAIDS in an Ethiopian Town. Leiden:African Studies Centre (Brill Academic Publishers).

- 2008. Under the cloak of secrecy: Sexuality, HIVIAIDS among men who sex with men in Addis Ababa. Unpublished document.

Van Den Borne, F. 2005. Trying to survive in times of poverty and AIDS. Women and multiple partner sex in Malawi.Amsterdam: Het Spinhuis.

— 200I. "No strength": Sex and old age in a rural town in Ghana. Social Science and Medicine. 53: I383-1396.

Wolde-Mariam, M. 1991. Suffering under God's environment: A vertical study of the predicament of peasants in North-Central Ethiopia. Berne: African Mountains Association and Geographica Bernensia. 


\title{
Sexual identity, sexual relationships and risk among young people in South Africa
}

\author{
M'zamani Benjamin Makhubele*, \\ Pumla Ntlabati and Warren Parker
}

\section{Introduction'}

Identity is a concept that involves the relation between the self and others, including attitudes, beliefs and values about what commonalities and differences exist between oneself and others.

Identity gives us a location in the world and presents the link between us and the society in which we live... [it] gives us an idea of who we are and how we relate to others and to the world in which we live... [it] is most clearly defined by difference, that is, by what it is not. (Woodward 2002, I)

* Centre for AIDS Development, Research and Evaluation (CADRE), Johannesburg (South Africa), benjamin@cadre.org.za

I This research was made possible through financial support provided by the President's Emergency Plan for AIDS Relief (PEPFAR) through the United States Agency for International Development (USAID) and Johns Hopkins Health and Education South Africa. The opinions expressed herein are those of the authors and do not necessarily reflect the views of the USAID.

Makhubele, M. B., P. Ntlabati and W. Parker. 20I2. Sexual identity, sexual relationships and risk among young people in South Africa. In Chic, chèque, choc. Transactions autour des corps et stratégies amoureuses contemporaines. 153-167. Actes des colloques genre et développement. Berne: DDC-Commission suisse pour l'UNESCO; Genève: IHEID. 
Sexual identity relates to the complexity of factors connected to sexuality, in relation to individual perceptions and social constructions of gender. Sexual identity is also linked to the repertoire of sexual practices related to the expression of sexuality.

Sexual identity in contemporary literature often devolves to a focus on non-heterosexual identities, with surprisingly little focus on the dimensions of heterosexual identity. An understanding of heterosexual sexual identity is particularly pertinent in the context of the severe HIVIAIDS epidemic in sub-Saharan Africa, given that the epidemic is primarily driven by heterosexual sexual intercourse.

In Southern Africa, the HIV epidemic is classified by UNAIDS as hyperendemic and in South Africa, prevalence amongst pregnant females exceeds $30 \%$ and prevalence for males and females aged I5-49 is $16.2 \%$ (Shisana et al. 2005). Whilst multiple factors influence the risk of HIV infection during heterosexual intercourse including co-infection with other sexually transmitted infections, the circumcision status of males, sexual practices including anal sex, and consistent and correct condom use, the primary factor related to sexual identity has to do with having multiple and concurrent sexual partners. Expression of sexual identity and risk of HIV infection is also related to underlying socio-economic conditions such as unemployment and mobility, and socio-cultural factors including late marriage and low levels of cohabitation amongst unmarried couples (Parker et al. 2007).

This paper draws on qualitative data gathered nationally amongst unmarried males and females aged 20-30 exploring concepts of the individual and the social construction of sexual identity in the context of a severe HIVIAIDS epidemic².

\section{Self esteem and peer values}

The concept of self-esteem is related to an individual's sense of self worth and involves an inter-relation between individual psychological perceptions, and values and perceptions of others in one's social context. In relation to sexual identity, self-esteem is shaped by similar factors. 
According to Kahn (2005), abstinence, as part of the mainstream interventions to address HIV in South Africa, is informed by models that emphasise the individual and individual agency over sexual choicemaking, while ignoring the social context within which individuals live. Articulation and perception of peer values influence an understanding of what is considered to be normative and appropriate sexual behaviour. In a study among young males in Mexico, Reysoo (2005) found that young people experienced strong pressure from their peers to achieve their sexual debut in order to be considered men. Anfred (2003) writes that in northern Mozambique, along with initiation rituals, young girls had to have sex to be considered adult and capable women.

In South Africa, late marriage is a key factor that results in periods of two decades or more where the majority of post-teenage young adults are not in long-term sexual relationships. Rates of marriage only increase beyond $50 \%$ among populations in their 40 s. Additionally, very few young people cohabitate with their sexual partners (Parker et al. 2007).

In our study, focused on sex amongst 20-30 year olds who are unmarried, sex is considered to be normative by both sexes, in contrast to abstinence which is seen as aberrant and associated with being seen as mad or as a fool.

The guys are full of criticism. They will say you are a fool for not having sex. You have all the nice girls but you are not sleeping with them. (Male, 23, Western Cape)

Interviewer: If people knew you were abstaining, what do you think they'd say?

Interviewee: I can think of many things they can say. Like that I am a fool, or l'll go mad. (Female, 25, Western Cape)

They will say "you are stupid" - the clever ones are the ones who are having sex. (Female, 27, Mpumalanga)

To be perceived as abstinent was also associated with negative gossip and labelling, as well as a sense of need to conform.

It is really painful when you hear all the stuff that is said about you, girls gossip so much. We really get a lot of pressure from them you know. (Male, FGD 20-30,Western Cape) 
The society in which you live will give you negative labels which will lead you to wanting to show them that you are not what they think you are. Then you end up engaging in such activities, just to show them that you can propose and be accepted by a girl. (Male, 28, Mpumalanga)

For some however, it is possible for self-esteem to run counter to social norms (Kahn 2005).

Interviewer: How do people react to your decision (to abstain)? Interviewee: They talk. People never get satisfied, and you will never satisfy people. They do not believe me, and they will never believe me. The thing is that as a person I know myself and what I live for. (Female, FGD 20-30, Mpumalanga)

The findings of our study suggest that many young adults position themselves within perceived norms of masculinity and femininity that require one to be seen as being sexually adventurous. For some, choosing not to fit into this form of identity includes going against the tide of negative comments and labels, while steadfastly holding on to their beliefs and decisions not to engage in sexual activities. Heterosexual identity can thus be seen as incorporating normative and counter-normative constructions, within the context of heterosexual practice.

Constructs of masculinity are strongly related to the notion that male sexual identity is linked to an overwhelming need to be sexually active on a sustained basis.

I believe that there is no man who can voluntarily choose to abstain. Anyone who tells you that they are abstaining, they are lying. The truth is that they are trying to get some but are not getting any. All men will jump at an opportunity to have sex. It is only if they do not know how to present themselves to women, or because they are afraid of propositioning that they will abstain. Those like us will never abstain. (Male, FGD 20-24, Gauteng)

Promiscuity and the need for sex are presented as "involuntary" behaviours that are beyond the control of men. According to this conception, a real man would never miss an opportunity to have sex, and a 
man who is not having sex is not doing that out of choice (he is lying), but out of fear of women. Fear is a concept used to denote unmanliness, as a man should be brave and not fear anything, least of all a woman. This dominant discourse of masculinity dictates that a woman should be pursued sexually, and not feared. The ability to proposition women and engage in sexual activities is rewarded with being part of the group, becoming one with the masculine whole, with a high value placed on such exploits.

Mfecane et al. write about the "outie" amongst men in Soweto and describe it as a hegemonic masculinity within the context of their study. They describe one of the facets of such identity as mainly characterised by competing for girls and a "constant need to prove oneself to others who share... expectations of this masculinity" (2005, 100). Hunter writes about a similar concept, known as isoka amongst the Zulu in KwaZulu-Natal, which describes a man who is successful with women, highlighting the value placed on men who secure girlfriends, particularly multiple girlfriends (2003).

Having many sexual partners is closely connected to notions of manhood and masculinity in our study, with resistance resulting in labels such as being a boy, or "gay", or scared of women (isishumane). In contrast, having many girlfriends secures praise as being a "top dog".

Interviewer: Can you tell us more about this idea of wanting to be popular? Do your peers expect you not to have many girlfriends?

Interviewee: Like when you do not have many girlfriends it is like you are a moshemane [boy]. (Male, 18, Gauteng)

They will say you are gay or something. They can mock you. (Male, 18, Gauteng)

We laugh at you, usishumane [scared of women]. (Male, FGD 2030, Western Cape)

Interviewer: And if they see you with a whole lot of different girls?

Interviewee: They will say, 'hayi, uyinja wena [you are a top dog]! You are the man!' (Male, I8, Gauteng)

Such constructs are not wholly or exclusively linked to being male, and in our study we found similar comments from females. Concepts of 
femininity are also linked, amongst women, to validating multiple and concurrent partner relationships.

Let us say I am in a relationship, and I have seen Peter before him; who was giving me good sex. I have to have sex with this guy because he is my boyfriend. But I will still go to Peter now and then because of the good sex that he gives me. That creates a list of boyfriends I have sex with at that time. Also to find that there is Sam as well whom I have not seen for a long time and we meet again. I will also think that I once had a good relationship with him, then we continue and also have sex with him. Because of such things you end up with up to five people that you have sex with at a given period. (Female, FGD 20-24, Gauteng)

Women in the study express a very strong sense of identity as being in control of their sexuality and determining the extent of their sexual relationships. In the context highlighted above, it is the woman who decides with whom and when to have sex. It is apparent from the quote that the woman's need for good sex is an entitlement that may, out of necessity, go hand in hand with having concurrent sexual partners. Such constructions run counter to the idea dominant in many feminist interpretations of female sexual agency among African women as being largely and inevitably determined by structural factors such as socio-economic factors operating in concert with patriarchal cultural values (Campbell, Mzaidume and Williams 1998; Schoepf 1992; Wood and Jewkes 1998; Varga 1997).

You see somebody, very sexy, tight ass, six-pack, well built and you feel you have lust for him. And you feel you just do not want to miss him. (Female, FGD 20-24, Gauteng)

Whilst some young women perceive the norms of their peers to be accepting of multiple sexual partnerships, male views of female promiscuity are disrespectful, with associations made to being "bitches" and "carriers of disease".

I think of them as bitches, because a woman, I mean as a man, when you meet a woman now and she agrees to go and have sex with 
you, you wonder how many men she does that with. The same impression that she gave me the first time is the one that I am going to treat her with for the rest of her life. (Male, 2I, Gauteng)

Men view women who pursue their sexual desires with suspicion. A woman who readily gives in to male sexual advances is perceived to be operating beyond the confines of male perceptions of feminine sexuality - she is thus an aberration.

\section{Sexuality and love disconnects}

Many respondents described situations where they have a "main" sexual partner and one or more "other" partners:

I can have others in the same area but they have to know that there is someone in my life. If they can't accept that then we part ways immediately. I mean I don't lack for nothing, it was more a favour I was doing for her anyway. (Male FGD, 20-30, Western Cape)

Relationships with "main" or primary partners are characterised by intimacy, affection and long-term plans.

Interviewee: We are like friends. We talk about everything and anything. There is communication and I can see that this relationship is going somewhere, unlike the other one which I can say was based on sex. Whenever we met he would like to bang. But I think the current one is going to be a long term thing.

Interviewer: Can you say you are faithful to your current boyfriend?

Interviewee:Yes I am. (Female, 23, Gauteng)

Faithfulness, however, is not a concept that is linked to fidelity. Rather, it is linked to ensuring that one's partner does not know about one's infidelity. This applies to both males and females.

As for me I have my girlfriend, the one that I spend most of my time with. I am faithful to her because even when I have other 
girlfriends I do not walk around with them for her to see me. I hide the other girlfriends. But the others that I sometimes have sex with know that I have a girlfriend and I do not spend time with them. Maybe I only see them when we meet at nightclubs and take them to my room. We do not make appointments and stuff. (Male, FGD 20-30, Gauteng)

I started seeing someone else... after the baby was born. He works at the army but I told him that I have a child with someone and it was no problem. We are very tight and I'm still seeing him even now. But the thing is... I continue to see them both... none is aware of the other. (Female, 26, Eastern Cape)

In our study, relationships with "other" partners are characterised by friendships between people who enjoy each other's physical intimacy but do not aspire to be long-term partners; rather the parties desire temporary relationships purely for sexual purposes:

The others is like, we do not even call each other. Maybe I can call one after a week or we meet at clubs and then become intimate. It is when I meet some of them in a club that I remember; oh by the way she is my chick. Then I invite her to my place. We get there, do our thing and come back. Just like that. It is like I know they are always there but I do not see them everyday. But you know they are there. Sometimes when my friends visit and want some action I refer them to the same girls. (Male, 2I, Gauteng)

\section{Sexuality and agency}

The study illustrates unexpected balances in sexual agency and openness to having multiple and concurrent sexual partners in expressions of both masculine and feminine identity (see also Makhubele 1999). Both women and men actively engage in behaviours and activities that are aimed at satisfying their sexual urges, including pressurising potential sexual partners into giving in to sexual advances:

Interviewer: Other than women at shebeen ${ }^{3}$, women who are drunk, why do other women who are not drunk have one-nightstands? 
Interviewee: It is because they are too used to sex. They like it a lot. (Female, FGD 20-30, Mpumalanga)

Participant I:Sometimes you find that it is the woman who asked the man to go and have sex, simply because she is drunk.

Participant 2: But some women do that even when they are sober. Some go out to drink knowing exactly what she wants to do once she is drunk. So in that case she does not do that because she is drunk, she just drinks to make us think that what she does she does because she is drunk whereas she has planned to do it long before entering the tavern.

Participant 2: Some know that so and so, a guy they like, drinks at a certain tavern so they go there and drink and make advances towards him. (Female, FGD 20-30, Mpumalanga)

I have had some women who pressurised me to have sex with them to prove that I like them. Sometimes you feel that you are not there and this woman pressurises you to do it to show your love. (Male, 23, Gauteng)

Women's expressions of sexuality, particularly their power to seduce men, are generally reported to be undesirable and destructive in patriarchal societies, and therefore need to be controlled (Fataneh 2003). This line of thought is influenced by the belief that women's sexuality has to be subservient to that of men - that women do not have sexual desires for their own sake and interests. It is unfortunate that the idea of women's subservient sexuality, that women have sex to satisfy men, dominates sexual and reproductive health literature to this day. This conceptualisation of women's sexuality denies women agency and invalidates women's right to sexual pleasure independent of men.

Our findings reveal that young women in South Africa see their sexual identity as linked to self-gratification, including going to places where alcohol is consumed, where they can feign drunkenness, and get people to satisfy their sexual desires. Particular meeting places - predominantly bars and shebeens - provide a social space where this is possible. By presenting themselves as being at a shebeen to drink, they downplay their intentions of finding a male partner. 
Both men and women trade sex for economic advantage, often with people who are older than them.

You may be at a party and there's this older woman who has you "sniped" (meaning she has you marked) and you're also interested in her money, after all most guys are swayed by money. I know a case where the guy woke up on her couch and she was busy with him. He took her to ask about what she was doing she told him she'd take care of him after all. (Male, FGD 20-30,Western Cape) Male: Age is not that important, you can have an older partner if she's monied and has a car. In fact, this also applies to women.

Facilitator: Are you saying it's common for men to get involved with older partners?

Male: It's only done for the money... (Male, FGD 20-30, Western Cape)

I think we get blinded by money and this often leads to cheating. (Female, FGD 20-30, Eastern Cape)

It is worth noting that there is very little stigma attached to this type of relationship. Wojcicki (2002) writes about the concept of ukuphanda (sex-for-money exchanges) and notes that women who engage in this behaviour in Soweto and Hammanskraal, South Africa, do not describe themselves as commercial sex workers, experience less stigma in society, and are considered to be engaged in this type of activity for survival purposes.

Sex-for-money exchange by males challenges the dominant notion of masculine identity that presents males as providers in sexual relationships. This was not seen as unmanly however, even in a focus group of male-only participants, where the issue was discussed extensively. This is perhaps partly linked to underlying economic conditions where unemployment is widespread, and thus masculinity is reshaped in relation to the contemporary situation people find themselves in.

With regard to transactional sex, young people in this study construct a discourse of AIDS that points to desperation as the reason for their vulnerability. Although older partners regard transactional sex as a risk for HIV infection, such behaviour is rationalised and recast as a means of survival among younger people.

Condom use is another area where certain constructions of 
female agency have suggested that women are disempowered (Woods et al. 1998; Varga and Makubalo 1996). Such arguments are also pervasive in the literature that argues in favour of the costly development of microbicides for HIV prevention, where assumed lack of control over male condoms is seen to necessitate the development of a "femalecontrolled" barrier method (International Partnership for Microbicides 2005). In our study, many women were confident and assertive when it came to male condoms usage.

Interviewer: When do you use it [condoms]?

Interviewee: When I tell him that we should use it. We use it when I bring condoms and tell him that I want us to use them. (Female, 26, Mpumalanga)

Interviewer: Do men agree to use condoms?

Interviewee: With me if he does not want to use condoms he better leave me alone. Even my ex-boyfriend I used to tell him that if he does not want to use a condom he should just leave me alone and sleep. (Female, 27, Mpumalanga)

For some women, relationships were terminated to their discontent because their male partners did not want to use condoms. Examples of lack of agency amongst women who wanted their partners to use condoms were few and far between.

When asked if there is anything that they do not understand about HIV and AIDS, participants generally responded that there was nothing that they did not understand. Despite such a level of understanding, respondents engaged in risky sexual behaviours such as having multiple partners:

We know that we are committing suicide [by having multiple partners], but you may be infected even when you are faithful. (Female, FGD 20-30, Mpumalanga)

In this context, despair and fatalism about death from HIVIAIDS plays a significant role in sexual identity. There is recognition of risk for one's own actions and, given the normative acceptability of having multiple partners amongst both sexes, a sense of inevitable risk prevails because of the actions of other partners. 
Knowledge of risks associated with non-condom use does not necessarily translate into condom use for some respondents in our study. In particular, condom use was seldom sustained with main partners:

Facilitator:Which HIV prevention information is strong enough to be acted upon?

Participant: Condoms.

Facilitator: Is it easy to use condoms?

Group:Yes it is.

Facilitator: It is easy but we do not use them?

Participant:Yes we do not. (Female, FGD 20-30, Mpumalanga)

Facilitator: I am talking here about the main one [main partner], do we use condoms with those? [Silence].

Participant I: They are very few who use condoms with those, most of us do not condomise with our main boyfriends.

Facilitator: What HIV prevention strategies are used with the main boyfriend?

Participant I:There is nothing.

Participant 2: Nothing.

Facilitator:Are we aware that we can get HIV because of that?

Group:Yes.

Facilitator: So what do you do about it?

Participant 3: There is nothing that we are doing about that. (Female, FGD 20-30, Mpumalanga)

Condom use and sexual pleasure are interlinked - with condoms being associated with diminished sensation and intimacy (PrestonWhyte and Zondi 199I;Abdool Karim et al. 1992).

\section{Conclusions}

Heterosexual sexual identity is a generally unexplored area of research, yet particularly pertinent in the context of burgeoning heterosexual HIV epidemics in many African countries. Sexuality and sexual identity are interlinked, and in a context of high rates of HIV infection, such a risk is intertwined with expressions of sexual identity; heterosexual intercourse being one of the main vectors of HIV infection. 
In our analysis of heterosexual identity amongst young adults in South Africa, we find that masculine and feminine identities have many common elements. Our findings contradict prevailing discourses that position men as sexually acquisitive and dominant over women, in a context where women are positioned as largely disinterested in sex, and predominantly oriented towards monogamy and faithfulness.

We find there is a prevailing pattern of concurrent sexual partnership that is acceptable within the normative frameworks of both sexes. Underlying factors include the normalisation of sexual desire, the perceived need for sexual pleasure, and sex as a means to address other parallel needs, notably economic needs. In this context, there is a blurring of common assumptions about the severity of gender power, where it is assumed that males wield ultimate power. Instead, it is found that similar rationales, practices and levels of agency prevail between the sexes. This is also evident when it comes to male condom use, where it has been assumed that men have ultimate power to determine whether or not a condom is used.

In the present context of a severe HIV epidemic, a range of psychosocial factors related to self-esteem and sexual identity come together to work against HIV risk reduction. The challenge is to understand how these identities can be called into question with a view to mitigating risk. Simplistic concepts that focus on individual behaviour, such as "abstain, be faithful, and condomise" (also known as $A B C$ ) have little resonance in this social context, and there is no heightened understanding that having many partners, in particular concurrent partners, is a significant risk factor for HIV infection. It is in this area that sexual identities need to be reframed - and in particular in this context of high risk of HIV infections that the normative views associated with risky practices need to be challenged.

\section{References}

Abdool Karim, S.S., Q. Abdool Karim, E. Preston-Whyte and N. Sankar. 1992. Reasons for lack of condom use among high school students. South African Medical Journal. 82: 107-I I0.

Anfred, S. 2003. Contested constructions of female sexualities: meanings and interpretations of initiation rituals. Paper presented at the 4th International IASSCS Conference Sex and secrecy, University of the Witwatersrand, 22-25 June.

Campbell, C., Y. Mzaidume and B.Williams. 1998. Gender as an obstacle to condom 
use: HIV prevention amongst commercial sex-workers in a mining community. Agenda, 39:50-59.

Hunter, M. 2003. Masculinities and multiple partners in KZN: the making of Isoka. Paper presented at the 4th International IASSCS Conference Sex and secrecy, University of the Witwatersrand, 22-25 June.

International Partnership for Microbicides. 2005. Microbicides: An essential HIV prevention strategy for achieving the Millennium Development Goals. A policy paper prepared by the International Partnership for Microbicides. www.ipmmicrobicides.org

Kahn, L. 2005. The narratives of sexual abstinence: a qualitative study of female adolescents in a Cape Town Community. CSSR Working Paper No. 105. Centre for Social Science Research: University of Cape Town.

Karlyn, A. 2003. Intimacy revealed: the language and context of adolescent sexual experimentation in Maputo, Mozambique. Paper presented at the 4th International IASSCS Conference Sex and secrecy, University of the Witwatersrand, 22-25 June.

Makhubele, M.B. 1999. Perceptions of adolescents in Khayelitsha, Cape Town: On sexual and reproductive health. A thesis submitted to the Department of Anthropology and Sociology in partial fulfilment of the requirements for a Masters degree.

Mfecane, S. et al. 2005. The practice of masculinity in Soweto shebeens. In Rethinking masculinities, violence and AIDS, Vol.I. (Eds.) D. Gibson and A. Hardon. 88-109. Amsterdam: Het Spinhuis Publishers.

Parker W., M. B. Makhubele, P. Ntlabati and C. Connolly. 2007. Concurrent sexual partnerships amongst young adults in South Africa: challenges for HIV prevention communication. www.cadre.org.za

Preston-Whyte, E. and M. Zondi. 1991. Adolescent sexuality and its implications for teenage pregnancy and AIDS. CME. 9: | 389-1394.

Reysoo, F. 2005. Social construction of masculinity in Mexico. In Rethinking masculinities, violence and AIDS, Vol.I. (Eds.) D. Gibson and A. Hardon. 7-I8. Amsterdam: Het Spinhuis Publishers.

Schoepf, B. G. 1992, Women at risk: case studies from Zaire. In In the time of AIDS: Social analysis, theory and method. (Eds.) G. Herdt and S. Lindenbaum. 259-286. London: Sage.

Shisana O., T. Rehle, L. C. Simbayi, W. Parker, K. Zuma, A. Bhana, C. Connolly, S. Jooste and V. Pillay. 2005. South African national HIV prevalence, HIV incidence, behaviour and communications survey. Cape Town: HSRC Press.

Wojcicki, J.M. 2002. commercial sex work or ukuphanda? Sex for money exchange in Soweto and Hammanskraal Area, South Africa. Culture, Medicine and Psychiatry. 26 (3): 339-370.

Wood, K. and R. Jewkes. 1998. "Love is dangerous thin": Micro-dynamics of violence in sexual relationships of young people in Umtata. Pretoria: Medical Research Council.

Woodward, K. 2002. Identity and difference. London: Sage. 
Varga, C. and L. Makubalo. 1996. Sexual non-negotiation among Black African teenagers in Durban. Agenda. 28: 3-38.

Varga, C. A. 1997. Sexual decision-making and negotiation in the midst of AIDS: Youth in KwaZulu-Natal. South Africa. Health Transition Review. 7 (Suppl. 2): I3-40. 



\title{
Pag-ibig (Love), Pagnanasa (Desire): Filipino adolescents and sexual risks
}

\author{
Maria Theresa D. Ujano-Batangan*
}

\section{Introduction}

The total Philippine population is pegged at 84.2 million (ISSA 2005). Based on the 2000 statistics, there are I0I males to 100 females. According to the Young Adult Fertility Survey (2002), there are 15.0 million young individuals in the I5-24 age group; of this figure, 7.9 million are within the 15-19 age range, and 7.I million are between the ages 20 to 24 years old. The Philippine Statistical Yearbook (PSY) 2004 report further noted the following distribution among the youth: 8.9 million are within the age range of 10-14;8 million are within the 1519 age group; and 7 million are within the 20-24 age group. Using the WHO definition of adolescence, adolescents aged 10-20 years old comprise a significant portion of the Philippine population.

The period of adolescence among Filipinos is best defined by the local terms, pagbibinata and pagdadalaga. These words reflect the process of becoming and a stage of blossoming, from childhood to adulthood, a process that is believed to be replete with challenges centred not only around the definition of one's self, but also on establishing

* Psychologist, University of the Philippines Diliman, tdujanobat@ gmail.com

Ujano-Batangan, M. T. D. 2012. Pag-ibig (Love), Pagnanasa (Desire): Filipino Adolescents and Sexual Risks. In Chic, chèque, choc. Transactions autour des corps et stratégies amoureuses contemporaines. 169-182. Actes des colloques genre et développement. Berne: DDC-Commission suisse pour I'UNESCO; Genève: IHEID. 
one's perspectives and values regarding the different domains of one's sexuality. In conceptualizing the characteristics of the period of adolescence, various themes have emerged from research done in this area (Sobritchea and Ujano-Batangan 2003), including:

- Adolescence as a period covering different age ranges. Some respondents defined this to be the period of 10-19 years of age, while others pegged this at 13 to 24 years. Others differentiated between 13-19 years as the teenage years, while 15-30 years were described as the age of youth. Based on this, there seemed to be an ambiguity in defining which ages in particular are included in adolescence.

- Adolescence as a developmental stage characterized by particular, typical and shared developmental tasks and characteristics; variations of which are related to individual and contextual factors. These developmental changes are further categorized into: physical/biological changes, cognitive changes, and socio-emotional changes.

- Adolescence as a point of transition from childhood to adulthood. Most respondents believe that adolescence is a point whereby the individual learns the necessary skills that are needed for dealing with adult concerns and challenges.

Adolescence is known as a time of extensive changes occurring in the various facets of human development. It is at the period of adolescence when Filipino males and females explore intimate and sexual relationships. Adolescence is a critical time for experimentation and risk taking.

The results of the Young Adult Fertility and Sexuality Study (YAFS) (Natividad and Marques, 2004) show that $31.3 \%$ of male respondents and $15.7 \%$ of female participants reported that they have had sex. Among the 15 to 19 age group, $17.8 \%$ of males and $6.0 \%$ of females answered in the affirmative when asked if they had had sex. Of those who had sex from the said age group, $43.8 \%$ of males and $28.1 \%$ of females stated that they had wanted it to take place the first time. These results show that for a majority of these adolescents, their first sexual intercourse was either unplanned or against their will.Very few of the respondents used some form of contraception during their first sexual coitus (males: $32.5 \%$; females: 12.3\%) and during their last 
intercourse (males: $27.3 \%$; females: $17.1 \%$ ). Furthermore, $44.8 \%$ of male adolescents in the 15 to 19 age group stated that they have more than one sex partner; while $10.5 \%$ of the females reported the same.

The YAFS study also reported that II \% of the Filipino males and females sample aged 15-24 have experienced sex partners of the same gender (Crisostomo 2003). Males account for $52.6 \%$ of the responses, while females account for $47.2 \%$. Most of the participants reported that they have engaged in such behaviours while still in school. Only $46.4 \%$ of same sex partnerships are "paid", the rest "happened because they are in a relationship".

Gleaning from the aforementioned findings, it is important to understand the adolescents' contexts and constructions of these sexual relationships and their attendant risks. This is a necessary step to ensure that services provided to them are appropriate and relevant, as the period of adolescence is also an opportune period for interventions which would allow young individuals to acquire the necessary cognitive, emotional and social skills necessary for addressing the demands of intimate and sexual relationships.

\section{Objective and scope}

This presentation will summarize findings from research and workshops we have conducted with different sub-populations and subcultures of young individuals (i.e. in-school and out-of-school; rural and urban; abused and prostituted adolescents; across socio-economic status) in the area of adolescent sexuality and sexual health, focusing on the contexts and constructs of young Filipinos engaged in sexual partnerships, and the implications of these contexts and constructs in terms of the sexual risks they face in this phase of their development. This is by no means an exhaustive discussion on the said topic.

\section{Findings}

\section{Contexts and constructs of sexual partnerships}

Barkada (Peer Group)

While it is clear that friendships are vital throughout life, there seems to be something special about the role of the peer group or barkada, 
during adolescence. Peer groups provide adolescents with a source of social activities and support. It is in this context that they are able to explore and experiment, given the relatively egalitarian atmosphere pervading among peer relationships. The barkada also facilitates friendships with the opposite sex, with friendships identified by most of the young respondents as the context of romantic relationships. It is in or through their peer group or barkada that adolescents usually meet their future partner/s. If romantic relationships are established outside the group, the boy/girl friends are integrated into the young individuals' peer group. The peer group allows, pushes and mediates the development of the relationship. They also help in the reconciliation and termination of relationships.

Proximity plays a very crucial role in allowing individuals to get to know each other and for attraction to ensue. Friends are chosen (at least initially) from a pool of peers who share the same social environment. In adolescence, friends go to the same school, belong to the same organisation, same community, same territory/gangs (for young people living in the streets) and are similar in ethnic and socioeconomic status. Similarity of demographic characteristics, personal attributes, activities, and social behaviour, are observed among friends, and facilitate the "liking" process. Generally, adolescent friends tend to be similar in academic attitudes, achievement and aspirations and enjoy the same leisure activities. Similarity between friends makes it easier to achieve an intimate relationship.

Young females rationalise their decision to have sex based on what they perceived to be the norms in their peer group. Susceptibility to conformity with peer group standards is typical among adolescents who are still in the process of negotiating their own values amidst the differing influences of various individuals and groups in their lives (e.g. friends, parents, teachers, etc.). Conformity to peer group norms is a consequence of the adolescents' tendency to be more sensitive to the needs and standards of others, placing them ahead of their own. Investigations into adolescent peer groups revealed that peers might be one of the primary reasons for adolescents' initiation to sex; however, more females than males are pressured into premarital sex by peers. Sexual behaviours among girls are greatly influenced by the behaviour of their same sex friends. Males, on the other hand, appear to pick their friends based on similarity in sexual activity. 
While intimate relationships first arise in early adolescence, it is not a unique feature of this stage. Adolescents also value forms of intimate self-disclosure or sharing of intimate information among their own friends. These intimate conversations contribute to the adolescent's sense of self-worth, as well as to the development of social skills and the sense of security necessary for close relationships later in life. Being able to talk and disclose information yields positive feelings of self-affirmation, which can be the context for romantic relationships.

Paglabas (Dating)

Because of the term's romantic and sexual connotations, dating is not seen as a salient stage in the process of building a romantic relationship among Filipino adolescents, especially in rural areas. Although those in the urban centres and upper income groups may use the term, most adolescents prefer to use the term lumalabas which roughly translates to "going out together". Research shows that the purposes of paglabas among young individuals are:

- Recreation

- Companionship

- $\quad$ Status grading

- Socialisation for personal and social growth

- Sexual experimentation and satisfaction

- Partner selection

- Intimacy

Oftentimes, the process of paglabas is initiated within the peer group. Adolescents seldom go out with individuals they are not familiar with, except when members of their barkada are present. Places where adolescents frequent at this stage are malls, food establishments, movie houses, cafés, plazas, churches, etc. It is only after attaining a greater level of comfort and intimacy that potential partners go out on their own, which is when negotiations on physical boundaries and sexual intimacy commence. Though sexual intercourse is not considered to be "socially acceptable" at this point, adolescents may chose to explore various sexual behaviours.

Research on dating among adolescents in the Philippines identified gender differences in the values males and females place on the prac- 
tice of dating. Males perceive dating as a means to "satisfy sexual desires"; on the other hand, females see it as a way to "get to know the person better". This is also related to variations on how they perceive romantic relationships. Most males consider having relationships as sources of "experience", "fun" and "pleasure". Females on the other hand, consider "going steady" to assess their future partners in marriage. It is interesting to note that when males were asked as to what particular traits they would want their partner to possess, almost all the respondents, regardless of economic status, considered physical attractiveness, being demure, being sweet and being educated as essential. The female respondents, on the other hand, prefer their boyfriends to be responsible, loving, sincere and honest. Those in the lower income group expressed the importance of having a partner who is financially stable. While Filipino adolescent males initially focus on the external attributes of their partners, females tend to look for indicators of emotional maturity from their partners.

\section{Kami Na}

Young adolescents are engaged in various types of sexual relationships: they use the terms "committed" to signal a steady relationships and "casual" for sexual partnerships that are considered to be "fleeting" and "temporary". Beyond these two lay transactional sexual relationships.

Committed relationships are believed to be characterized by pagibig (love). They usually use the phrase kami na (a rough and crude translation of this phrase is "it's us") to verbalise the existence of a committed relationship. The word kami connotes "being one with the other" and denotes the merging of individualities and identities. Committed relationships therefore include the expectation of blurring physical and psychological boundaries among partners. In some cases, this is coupled with the female's identity being subsumed under the male's identity. Terms used to denote the partner are syota, girlfriend/boyfriend, bu, steady, hubby, mama/papa, mahal, babes, etc. Love for young individuals is associated with being together, which allows each person "to get to know the other and deepen the relationship". This need to be together necessitates spending more time together alone, which allows the partners to explore each other's sexuality. 
Adolescents believe that it is in the context of committed relationships that sexual activities are justifiable. Almost all of the female respondents and some of the male respondents in the research noted that they had sex with their partners as an expression of their love for the latter. Young individuals seldom use or verbalize lust as the basis for physical intimacy in committed relationships, which would be simply considered as bastos or profane. Invocations of love ("love conquers all") are very important, cutting across gender, socio-economic status, and variability of adolescent experiences. While love justifies sexual exploration, the search for one's "true love" delays sexual debut among adolescents. This need to find the one that is "meant to be" one's partner leads some individuals to abstain from sex or even from any committed and casual sexual partnerships.

Young individuals view romantic relationships as being extremely important for emotional support, providing them with constant companionship in their daily activities and concerns. Relationships are believed to evolve over time, though the notion of time is not measured solely in terms of days or months. Adolescents talk about tamang panahon (right time) for sexual intimacy to ensue. This notion of "right time" is negotiated in the relationship. Some adolescents go through the phase of M.U. or mutual understanding, where there is no commitment but there is recognition of the attraction and affection for each other. This may serve as a transition point to the emergence of a committed relationship. Adolescents believe that one should only engage in a romantic relationship when one is prepared; preparedness for them entails "maturity" - which they defined as the ability to handle the demands of the relationship. Sexual activities like necking, petting, and penetrative sex are closely tied with the level of intimacy achieved in the relationship. The value given to pananagutan (responsibility) and pagtitiwala (trust) are factored in significantly when defining a committed relationship.

The intense feelings of love and desire (pagnanasa) are considered to be intertwined and essential in a committed relationship; as such, the presence of the former legitimises sexual intimacy. The participants assume that when they are in love, sex will spontaneously happen.

Adolescent females also report that they had sex with their boyfriends to be able to keep them in their relationship. Holding on to their partners through sex assures them that they are still in love. 
Some male participants would also consciously plan on getting their girlfriends pregnant to permanently tie them into the relationship.

Some of the females expressed fear in the possible consequences of their refusal to respond to their partners' sexual demands. Their apprehension stems from various, expected consequences if they decline, such as: their partners "will get mad" at them, "will look for someone who is sexually available", "will leave" them, or "will get emotionally hurt". Males play on these fears in the process of initiating sex.

There are instances when notions and meanings associated with love - such as trust, responsibility, and desire to have children - are capitalised upon by males to force their partners into sexual submission, even if this is against the latter's will. Love may then be used as a justification in controlling one's partner, without due recognition of the latter's rights. Unfortunately, even the female participants do not recognise their claim to sexual rights in the context of a romantic relationship.

Some of the female adolescents also stated "impending marriage", which is an indication of the "seriousness" of the partner's commitment to the relationship, as reason for having sex. Tan et al. (200I) purported that "love and procreation sacralises sex and makes it acceptable even before marriage in certain circumstances... if love is present and if marriage is impending, then premarital sex may be allowed."

The practice of using condoms in committed relationships is oftentimes considered as generally unacceptable. For one, the readiness/availability of condoms demonstrates that the partner (especially the male) has been thinking and planning on having sex, which is contrary to the perspective that sex should be spontaneous. This is also not in consonance with the belief that sex in the context of a committed relationship is sacred. This issue is further complicated with the notions of trust and responsibility that govern adolescent relationships: when you trust someone, you should not feel the need to protect yourself and when you are a responsible partner, you need to be accountable for the consequences.

\section{Libog}

"Casual" sexual partnerships come with different labels/phrases, such as "one night stand", "flirtation", "Fubu (fuck buddies, friends with benefits)", "SEB (sex eyeball)" "seks lang", etc. More adolescent males admit to having these types of sexual partnerships than females. These 
terms denote that such partnerships are only "for releasing sexual energies" or "sexual urges", which adolescents locally call libog (lust). Lust is conceptualized by adolescents as something biological, characterised by bodily sensations that trigger arousal and create tension, which needs to be released/addressed. Some adolescents, most of whom are males, would tend to compartmentalise the concepts of lust and love, reporting that they love their partners in committed relationships but lust after another individual. This compartmentalisation allows individuals to explore sexual partnerships outside of committed relationships, which can lead to a condition of heightened risk.

Adolescents believe that the noncommittal nature of "casual" sexual partnerships allow individuals to be more open to explore sexual activities, without the need for committed relationships. The nature of partnerships ranges from "one night stands" to "fuck buddies" (FBs). While the former is characterised by non-permanent partnerships, the latter is characterised by a certain level of regularity, based on mutual need to sexually satisfy one another. It is however a cardinal rule among FBs that none should fall in love with the other in the process. Some adolescents, especially females, find these casual sexual partnerships as more "liberating" because they can negotiate the terms/conditions of engagement. One such condition may be on the form of protection, such as condom use.

Another form of sexual partnership, mainly driven by lust and desire, is the transactional relationship. These types of partnerships also characterised some adolescent relationships. Prostituted adolescents would narrate their experiences, highlighting their recognition that their bodies serve as objects of desire and as commodities in transactions. Though some of them are in committed relationships, they have learned to compartmentalise their lives as partners and as commercial sex workers (CSWs). Some even define boundaries, physi$\mathrm{cal}$ and behavioural, based on this form of compartmentalisation, not allowing their "customers" to kiss them on the lips (for females) for example, or not allowing them to give them oral sex (for males). Some CSWs narrate experiences of dissociating themselves from their bodies in the process of engaging in sex with a "customer", which allow them to cope with the dissonance that they feel. They may also use drugs to "deaden the bodily sensations" they feel or to lessen their inhibition in the sexual act. 
The "payment" for sex received by adolescent CSWs includes money, cell phones, cell phone load, tuition fees, clothes, access to particular high-end establishments, etc. Some transactional sexual partnerships may also become regular relationships later on. Variations on condom use are observed in these partnerships. "Customers" may prevent male CSWs from using condoms, and as they are being paid, the men easily oblige. On the other hand, female CSWs oftentimes do not know or assert their rights to be protected. Informed adolescent CSWs may use condoms in their initial encounters with the "customer", but refrain from doing so when the "customer" becomes a regular partner. More often than not, CSWs do not use condoms in the context of committed relationships.

Cyber space also presents additional contexts for casual and transactional sexual partnerships. Unlike physical, face-to-face sexual encounters, cyber sex presents a "safer" context for exploring one's sexuality. Some adolescents report that they prefer to engage in casual cyber relationships because they will not get pregnant or contract sexually-transmitted infections (STIs) and HIVIAIDS, and are less vulnerable to sexual abuse. They are also able to explore various persona as they engage with possible partners in cyber space. They recognize, however, the risk of "violations", when pictures or videos are "leaked" in cyber space, of dealing with "competition", or gaining a "negative reputation" that would block them from participating in particular chat rooms or groups. Initial sexual encounters in cyber space do not necessarily lead to sex eyeball, but if this should happen, the process of getting to know each other and engaging is thus facilitated. Sexual performance also becomes highly important in such a setting. Depending on what is considered to be desirable, there will be preferences for particular body types, sexual orientation and partnerships.

\section{Toma, droga}

According to young individuals, one of the salient factors that leads to initiation of sexual intercourse in committed and casual relationships is their participation in gateway behaviours. Gateway behaviours are defined as "mildly or moderately distressing activities, frequently selfdestructive", which often progress to increasingly risky behaviours (Whirtier et al. 2004). There is increasing evidence that these behaviours - e.g. getting intoxicated (toma), doing drugs (droga) - are linked 
to more serious activities which place young people at imminent risk. The gateway behaviour prominent among young males and females is getting drunk.

Doing drugs is another gateway behaviour that cannot be conclusively discounted as a risk factor in teenage sexual activities. Research participants have reported using marijuana and shabu (methamphetamine) prior to engaging in sex, especially casual and transactional sex, though they did not attribute their sexual activities as being triggered by said behaviour. These gateway behaviours facilitate the process of engaging in unplanned and unprotected sex.

Control, curiosity, gratification

Another theme that emerged in discussions among adolescents is the perception that they do not have control over their feelings, their partner's feelings and their subsequent behaviours. This response is more frequently attributed/associated with female adolescents. There is an observed outright acceptance of their perceived lack of control over their sexual behaviours and their submission to the sexual demands of their partners. They rationalised this by believing that this is what is expected in an intimate relationship. Unlike females, perceived lack of control reported by males is attributed to the presence of gateway behaviours, such as consuming alcohol or doing drugs. They see alcohol as triggering sexual excitement and inhibiting their ability to think logically. Consequently, they report that their judgment becomes clouded, even when faced with the possible consequences of their action.

Perceived lack of control is also associated to the notion of the "naturalness" of male sexual libido. Some of the males in the studies and workshops stated that male innately have an "interest in sex" as well as lust. They believe that once they have been excited and stimulated, they cannot do anything about their desire to have intercourse. This is further reinforced with the view that masculinity is tied with sexual experience and sexual prowess. Curiosity on the kind of pleasure that the act of sex can bring, as well as the expectation of gratification are other factors that contribute to the decision to have sexual intercourse, according to male adolescents. 


\section{Katawan}

Another factor that complicates the adolescent sexual exploration is their ignorance of their own bodies (katawan). Most young people are never encouraged to explore their bodies and the sensations associated with each body part. As they go through the changes brought about by puberty, they become more curious about the changes they are going through and try to secure information on this. They depend most of the time on peers, the Internet and other forms of mass media, for information. Unfortunately, the content of mass media creates unrealistic expectations of the adolescent body, which further on increases the dissatisfaction of adolescents with their own bodies (especially among females) leading to other risks and problems. They gain distorted information particularly about the human body and more generally about human sexuality. Myths regarding fertility, STIs, HIVIAIDS, pregnancy, contraception and protection still haunt young people, disabling them in making sound decisions regarding their sexuality.

\section{Sexual Risks}

Filipino adolescent and adult respondents agree that the following are the top five risk conditions confronted by young people (Sobritchea and Ujano-Batangan 2003): domestic violence/violence in intimate relationships; lack of access to adolescent reproductive health services; lack of education on sexuality and reproductive health; adolescent unsafe/risky sexual activities and behaviours; and mental health issues and problems (i.e. depression and suicide ideation).

At risk behaviours that adolescents engage in which increase the likelihood of adverse psychological, social and health consequences can be classified into the following: problem behaviours; health related behaviours; and school behaviours. The concept of risk does not have any direct translation in Filipino. Whenever adolescents and adults are asked to identify a term that best approximates the meaning of risk, they would always respond with the terms panganib, pagsubok and pakikipagsapalaran (Sobritchea and Ujano-Batangan 2004; Tan et al. 2000). The term panganib denotes negative outcomes/consequences of risk-taking, while the terms pagsubok and pakikipagsapalaran mean taking up the challenge with no definitive expectation of the nature of the consequences. Most adolescents use panganib in describing sexual risks, mirroring an inclination to define the consequences of risk taking 
as negative. In further pursuing the meaning of risk, adolescents perceive risks as factors that impede an individual's functioning, positive development, and the exercise and protection of one's rights. These concepts are related to the issues of perceived control, passivity, and probability.

Based on the statistics on abortion, the estimated number of abortions per year is 400,000 , with an abortion rate of 25 women per I,000, aged I5-44 (ISSA 2005). Abortion rates are at 16 per 100 pregnancies, with approximately 4 out of 10 of abortion complications treated in hospitals occurring among female youth I5-24, according to the YAFS two study sites.

Adolescents also experience violence in intimate partnerships. Several studies have noted that, more often than not, females are the ones coerced and violated by their sexual partners. The different physical forms of violence that females experience in intimate relationships include being slapped, dragged, spat on, drugged, punched, slammed, pushed/shoved, gripped tightly, slashed with a knife, kicked, choked, chained, pinched, threatened, thrown things at, and pulled by the hair. They also go through other forms of physical, psychological and economic abuse: rape, neglect, economic control, and being berated and humiliated. Prostituted young females have also experienced all these types of abuses from their male customers. A handful of males admitted to being physically abused by their partners. Individuals who have experienced abuse in intimate relationships (unless they break free and heal), are further cowed into submission, unable to assert themselves, and have their rights to be respected and protected. Even after the physical wounds have healed, the psychological trauma still persists. Abuse is further related to the lowering of an individual's sense of selfworth and self-efficacy.

Worth (1996) noted that there is difficulty among females in "distinguishing love and abuse". She attributed this to the commonly held belief among women that loving their partners entails being sexually available to them. Cultures have always portrayed "women as empty vessels where emotional and sexual fulfilment comes through reflecting their male lover's passion rather than their own". This is further reinforced by the process of socialization where young individuals are made to believe that "gender roles are natural which contribute to the beliefs that risky sexual behaviours are unavoidable" (Shears 2002). 
All these contexts and constructs associated with adolescent sexual relationships provide conditions of vulnerability to risks, which impedes their development of healthy sexual identity and their claim to sexual rights in sexual relationships. Intervention programs need to consider and further explore these factors in the process of developing relevant and appropriate strategies to reach young individuals in sexual and reproductive health promotion.

\section{References}

Conaco, C., C. Jimenez and C. Billedo. 2003. Filipino adolescents in changing times. Quezon City: UP Center for Women's Studies and Philippine Center for Population and Development.

Crisostomo, S. 2003. A study: More Pinoys having sex with same sex. Manila, July 12.

Guerrero, S. 1997. Focus on child abuse. In Breaking the silence:The realities of family violence in the Philippines and recommendations for change. (Eds.) S. Guerrero and C. Sobritchea, C. Quezon City: UNICEF and UP CWS.

Natividad, J. and M. Marquez. 2004. Sexual risks behaviors. In Youth sex and risk behaviors in the Philippines. (Eds.) C. Raymundo and G. Cruz. 70-94. Quezon City: Demographic Research and Development Foundation and UPPI.

Raymundo, C. and Cruz, G. 2004. Youth sex and risk behaviors in the Philippines. Quezon City: Demographic Research and Development Foundation and UPPI.

Sobritchea, C. and M. Ujano-Batangan. 2003. Adolescent reproductive health research and program assessment project. Unpublished research report.

Tan, M., M. Ujano-Batangan and H. Cabado-Espanola. 200I. Love and desire:Young Filipinos and sexual risks. Quezon City: Ford Foundation and UP Center for Women's Studies. 

